\title{
Five Elements Towards a Healthy Architecture
}

\author{
Veronique Leyten, B.A.S.
}

A thesis submitted to the faculty of Graduate Studies and Research

In partial fulfillment of the requirements for the degree of

Master of Architecture

M.ARCH (Professional)

School of Architecture, Carleton University, Ottawa, Ontario

Veronique Leyten (๑) Copyright 2008. 


$\begin{array}{ll}\begin{array}{l}\text { Library and } \\ \text { Archives Canada }\end{array} & \begin{array}{l}\text { Bibliothèque et } \\ \text { Archives Canada }\end{array} \\ \begin{array}{l}\text { Published Heritage } \\ \text { Branch }\end{array} & \begin{array}{l}\text { Direction du } \\ \text { Patrimoine de l'édition }\end{array} \\ \begin{array}{l}\text { 395 Wellington Street } \\ \text { Ottawa ON K1A 0N4 } \\ \text { Canada }\end{array} & \begin{array}{l}\text { 395, rue Wellington } \\ \text { Ottawa ON K1A 0N4 } \\ \text { Canada }\end{array}\end{array}$

Your file Votre référence ISBN: 978-0-494-40622-9

Our file Notre référence

ISBN: 978-0-494-40622-9

NOTICE:

The author has granted a nonexclusive license allowing Library and Archives Canada to reproduce, publish, archive, preserve, conserve, communicate to the public by telecommunication or on the Internet, loan, distribute and sell theses worldwide, for commercial or noncommercial purposes, in microform, paper, electronic and/or any other formats.

The author retains copyright ownership and moral rights in this thesis. Neither the thesis nor substantial extracts from it may be printed or otherwise reproduced without the author's permission.
AVIS:

L'auteur a accordé une licence non exclusive permettant à la Bibliothèque et Archives Canada de reproduire, publier, archiver, sauvegarder, conserver, transmettre au public par télécommunication ou par l'Internet, prêter, distribuer et vendre des thèses partout dans le monde, à des fins commerciales ou autres, sur support microforme, papier, électronique et/ou autres formats.

L'auteur conserve la propriété du droit d'auteur et des droits moraux qui protège cette thèse. $\mathrm{Ni}$ la thèse ni des extraits substantiels de celle-ci ne doivent être imprimés ou autrement reproduits sans son autorisation.
In compliance with the Canadian Privacy Act some supporting forms may have been removed from this thesis.

While these forms may be included in the document page count, their removal does not represent any loss of content from the thesis.
Conformément à la loi canadienne sur la protection de la vie privée, quelques formulaires secondaires ont été enlevés de cette thèse.

Bien que ces formulaires aient inclus dans la pagination, il n'y aura aucun contenu manquant.

\section{Canada}




\section{Abstract}

It is essential for contemporary architecture to produce healthy and sustainable environments for our habitation. While health has always been of central concern in human existence the changes brought on by globalization have negatively influenced the quality of 'healthy space' in architecture.

The proposed project for this thesis is the design of a recreation facility situated on the Bayview Yards site in Ottawa. There is a contentious relationship between this contaminated brownfield site, and the recreational program for uncontaminated bodies. This thesis will investigate the capacity for architecture to create a 'healthy site' and 'healthy building' for 'healthy bodies' through integrating the Chinese Five Elements (Wood, Fire, Earth, Metal, and Water), traditionally used in Chinese medicine to create balance producing health in the body, and the Cycle of Balance, a system engaging the Five Elements in various phases of interaction, both physically and qualitatively. These traditional systems will be integrated with contemporary healthy building practices to inform the 'healthy' design of the proposed recreation facility, revealing the capacity architecture has to address the concern for a healthy environment. 


\section{Acknowledgements}

I would like to take this opportunity to thank my thesis advisor Sheryl Boyle for her support, patience, challenging questions, and thoughtful contributions towards the completion of this thesis.

Thank you to my classmates for inspiring me with their creative minds throughout my education.

Finally, thank you to my family, Steve, and friends for their unconditional support and love, and for the motivation and encouragement during stressful times. I could not have done it without you. 


\section{Table of Contents}

\section{Abstract \\ Acknowledgments \\ Table of Contents \\ List of Tables \\ List of Illustrations \\ List of Plates}

Introduction 1

Chapter One: Traditional Chinese Culture

$\begin{array}{llr}1.1 & \text { Cosmology, Architecture, and Order } & 4 \\ 1.2 & \text { Five Elements Theory } & 6 \\ 1.3 & \text { Yin Yang Theory } & 8 \\ 1.4 & \text { Correlation Between the Five Elements and Traditional Chinese Medicine } & 11 \\ 1.5 & \text { Cycle of Balance } & 12 \\ 1.6 & \text { Feng Shui } & 15\end{array}$

Chapter Two: Sustainability \& Healthy Design

$2.1 \quad$ Green Building Movement $\quad 17$

2.2 Healthy Buildings and Sick Buildings 18

2.3 Health and Architecture 20

Chapter Three: The Site

$\begin{array}{lll}3.1 & 22\end{array}$

$\begin{array}{lll}3.2 & \text { History } & 23\end{array}$

3.3 A Contaminated Site 23

3.4 Current Conditions 24

3.5 Development Proposals 26

Chapter Four: Program \& Five Elements Theory

$\begin{array}{lll}4.1 & \text { Program } & 27\end{array}$

4.2 Five Elements Correlated to the Design of a Recreation Facility 27

4.3 Water: "Wet" Activities 29

4.4 Fire: "Dry" Activities 30

4.5 Earth: Healing and Therapeutic Activities 31

4.6 Wood: Common Spaces 32

4.7 Metal: Support Spaces 34

4.8 Building Location and Orientation 35 


\section{Chapter Five: Design \& Cycle of Balance}

5.1 Introduction 38

5.2 Building Massing and Form 38

5.3 Sustainable and Healthy Design Approaches 45

5.4 Wood Feeds Fire - Natural Ventilation 46

5.5 Fire Creates Earth - Thermal Mass and Rammed Earth 48

5.6 Earth Bears Metal - Site Remediation 52

5.7 Metal Collects Water - Rainwater Recovery 56

5.8 Water Nourishes Wood - Biowall 58

5.9 Wood Parts Earth - Natural Ventilation 61

5.10 Earth Absorbs Water - Light 62

5.11 Water Quenches Fire - Thermoactive Radiant Heating 65

5.12 Fire Melts Metal - Light 67

5.13 Metal Splits Wood - Thermodynamic Heating 69

$\begin{array}{ll}\text { Conclusion } & 71\end{array}$

$\begin{array}{ll}\text { Bibliography } & 73\end{array}$

$\begin{array}{ll}\text { Appendix A: Tables } & 76\end{array}$

$\begin{array}{ll}\text { Appendix B: Plates } & 80\end{array}$ 


\section{List of Tables}

Table $1.1 \quad$ Five Elements Chart

Bramble, Cate. Architect's Guide to Feng Shui: Exploding the Myth. Amsterdam: Architectural Press, 2003. (Table 2.2: A Chinese analogy map of five element theory)

Smith, Vincent M. and Barbara Lyons Stewart. Feng Shui: A Practical Guide for Architects and Designers. USA: Kaplan Professional, 2006. (Figure 2.17: The Five Elements)

Northern Shaolin Academy. Five Elements Chart, 2007,<http://www.northernshaolinacademy.com/new/NsaQigongMeditationFiveEle ments. asp> (accessed November 16, 2007).

\section{Table 1.2 Yin and Yang Chart}

Bramble, Cate. Architect's Guide to Feng Shui: Exploding the Myth. Amsterdam: Architectural Press, 2003. (Table 2.1: Some qualitative aspects of yin and yang)

Table 4.1 Recreation Facility Program, Table by Author, 2008.

Table 4.2 Building Orientation, Table based on content from Table 1.1. By Author, 2008.

Table 5.1 Cycle of Balance Related to Recreation Program, Table by Author, 2008. 


\section{List of Illustrations}

Figure 1.1 Yin Ying Symbol, Wu, Laurence C. Fundamentals of Chinese Philosophy. USA: University Press of America, Inc., 1986. pg. 160.

Figure 1.2 Cycle of Balance Diagram, Northern Shaolin Academy. Five Elements Chart, 2007,<http://www.northernshaolinacademy.com/new/NsaQigongMeditationFiveEle ments.asp> (accessed November 16, 2007).

Figure 3.1 Aerial View of Bayview Yards, City of Ottawa. Surveys and Mapping. Air Photos, 2005: 1:15,000. [computer file]. Ottawa, City of Ottawa, 2005.

Figure 3.2 Photomontage of Site, Photos by Author, 2007.

Figure 3.2 Site Context Images and Current Site Plan, Digital collage of photos and site plan. By Author, 2007.

Figure 3.4 Bob Chiarelli's Proposal for the Bayview Yards, Bob Chiarelli for Mayor. Bob's Vision: Chiarelli to Reclaim Bayview Yards A Community Green Space, November 8, 2006, <http://www.bobchiarelli.com/mayor_of_ottawa/04_vision_e.html> (accessed October 1, 2007).

Figure 4.1 Site Circulation Study, By Author, 2007.

Figure 5.1 Wood Feeds Fire: Digital Model of Building Massing, Digital schematic process model illustrating the relationship between the Cycle of Balance and the massing of program components. By Author, 2008.

Figure 5.2 Fire Creates Earth: Digital Model of Building Massing, Digital schematic process model illustrating the relationship between the Cycle of Balance and the massing of program components. By Author, 2008.

Figure 5.3 Earth Bears Metal: Digital Model of Building Massing, Digital schematic process model illustrating the relationship between the Cycle of Balance and the massing of program components. By Author, 2008.

Figure 5.4 Metal Collects Water: Digital Model of Building Massing, Digital schematic process model illustrating the relationship between the Cycle of Balance and the massing of program components. By Author, 2008.

Figure 5.5 Water Nourishes Wood: Digital Model of Building Massing, Digital schematic process model illustrating the relationship between the Cycle of Balance and the massing of program components. By Author, 2008.

Figure 5.6 Wood Parts Earth: Digital Model of Building Massing, Digital schematic process model illustrating the relationship between the Cycle of Balance and the massing of program components. By Author, 2008. 
Figure 5.7 Fire Melts Metal: Digital Model of Building Massing, Digital schematic process model illustrating the relationship between the Cycle of Balance and the massing of program components. By Author, 2008.

Figure 5.8 Earth Absorbs Water: Digital Model of Building Massing, Digital schematic process model illustrating the relationship between the Cycle of Balance and the massing of program components. By Author, 2008.

Figure 5.9 Water Quenches Fire: Digital Model of Building Massing, Digital schematic process model illustrating the relationship between the Cycle of Balance and the massing of program components. By Author, 2008.

Figure 5.10 Metal Splits Wood: Digital Model of Building Massing, Digital schematic process model illustrating the relationship between the Cycle of Balance and the massing of program components. By Author, 2008.

Figure 5.11 All Elements Balanced: Digital Model of Building Massing, Digital schematic process model illustrating the relationship between the Cycle of Balance and the massing the entire building. By Author, 2008.

Figure 5.12 Courtyard Plan, By Author, 2008.

Figure 5.13 Wood Feeds Fire: Natural Ventilation, Section Detail. By Author, 2008.

Figure 5.14 Fire Creates Earth: Rammed Earth Walls, Section Detail. By Author, 2008.

Figure 5.15 Images of Rammed Earth Wall: Nk'Mip Desert Cultural Center, Hotson Bakker Boniface Haden Architects and Urbanistes, Nk'Mip Desert Cultural Center, $<$ www.hbbharc.com> (accessed February 24, 2008.)

Figure 5.16 Master Plan of Site, Site Plan illustrating proposed project phases and remediation process. By Author, 2008.

Figure 5.17 Metal Collects Water: Rainwater Recovery System, Section Detail. By Author, 2008.

Figure 5.18 Biowall: Integrated Learning Centre, Queen's University, Kingston, Bregman + Hamann Architects, Queens University - Beamish-Munro Hall, 2008 $<$ www.bharchitects.com> (accessed February 24, 2008).

Figure 5.19 Biowall Diagram, Queens University and the contributors, Biowall, 2006, $<$ <ttp:///ivebuilding.queensu.ca/green_features/biowall> (accessed November 23, 2007).

Figure 5.20 Water Nourishes Wood: Biowall, Section Detail. By Author, 2008. 
Figure 5.21 Wood Parts Earth: Natural Ventilation, Section Detail. By Author, 2008.

Figure 5.22 Earth Absorbs Water, Process hand drawing. By Author, 2008.

Figure 5.23 Earth Absorbs Water: Natural Light, Section Detail. By Author, 2008.

Figure 5.24 Thermal Baths, Vals Switzerland - Peter Zumthor, Zumthor, Peter. Peter Zumthor Works: Buildings and Projects 1979 - 1997. Basel: Birkhauser

Publishers for Architecture, 1999. pg. 143-199.

Figure 5.25 Water Quenches Fire: Thermoactive Radiant Heating, Section Detail. By Author, 2008.

Figure 5.26 Fire Melts Metal: Light, Section Detail. By Author, 2008.

Figure 5.27 Metal Splits Wood: Thermodynamic Heating System, Section Detail. By Author, 2008.

Figure 5.28 Thermodynamic Heating System, IT Offices, Germany, Gauzin-Muller, Dominique. Sustainable Architecture and Urbanism: Concepts, Technologies, Examples. Basel: Birkhauser, 2002. pg. 210. 
List of Plates

Plate 1 Site Context Images and Current Site Plan, Digital collage of photos and site plan.

By Author, 2007.

Plate 2 Site Plan, Master site plan illustrating proposed project phases and remediation process. By Author, 2008.

Plate $3 \quad$ Ground Floor Plan, By Author, 2008.

Plate 4 Second Floor Plan, By Author, 2008.

Plate 5 Third Floor Plan, By Author, 2008.

Plate 6 Building Elevations and Sections, By Author, 2008.

Plate $7 \quad$ Building Elevations and Sections, By Author, 2008.

Plate 8 Detail Section 1: Wood Feeds Fire - Natural Ventilation, By Author, 2008.

Plate 9 Detail Section 2: Fire Creates Earth - Thermal Mass and Rammed Earth, By Author, 2008.

Plate 10 Detail Section 3: Metal Collects Water - Rainwater Recovery, By Author, 2008.

Plate $11 \quad$ Detail Section 4: Water Nourishes Wood - Biowall, By Author, 2008.

Plate 12 Detail Section 5: Wood Parts Earth - Natural Ventilation, By Author, 2008.

Plate 13 Detail Section 6: Earth Absorbs Water - Light, By Author, 2008.

Plate 14 Detail Section 7: Water Quenches Fire - Thermoactive Radiant Heating and Cooling, By Author, 2008.

Plate 15 Detail Section 8: Fire Melts Metal - Light, By Author, 2008.

Plate 16 Detail Section 9: Metal Splits Wood - Thermodynamic Heating, By Author, 2008.

Plate 17 Images of Model, By Author, 2008. 


\section{Introduction}

The green building movement proposes a shift towards a more sustainable environment. This shift can be referred to as the "fourth wave", with the other three principle shifts in human history being the agricultural, the industrial, and the information revolutions. ${ }^{1}$ This shift into the "fourth wave" is challenging architects to rethink the way buildings are constructed and used. ${ }^{2}$

"A green building subculture emerged, focusing on the technology of energy consumption at the expense of other architectural preoccupations, resulting in a number of buildings that scored well on energy performance but that failed to address a range of critical qualitative architectural issues." 3 The premise of this thesis goes beyond the conventional technological perception of sustainability and introduces a broader architectural discourse through integrating the Chinese Five Elements as a powerful catalyst for addressing the qualitative aspects of architecture and achieving a healthier, more sustainable built environment.

The Five Elements Theory is a fundamental philosophical basis for traditional Chinese science. ${ }^{4}$ The Five Elements (wood, fire, earth, metal, and water) establish relationships between phenomena. The Chinese elements are similar to the Greek classical elements of earth, air, fire, and water; "both theories are attempts to explain the bewildering complexity of things in the world in terms of a few simple familiar elements or forces" ${ }^{5}$ However unlike the Greek elements; the Chinese Five Elements are not considered material substances but rather "essences describing all matter and attributes". 6 The Chinese Five Elements are a viable catalyst for this thesis on the premise that the qualitative characteristics associated with them include site specific aspects such

\footnotetext{
1 John McMinn and Marco Polo. $41^{\circ}$ to $66^{\circ}$ Regional Responses to Sustainable Architecture in Canada. (Cambridge, Ontario: Design at Riverside, 2006), 3.

2 lbid., 3.

3 lbid., 3.

4 Cate Bramble. Architect's Guide to Feng Shui: Exploding the Myth. (Amsterdam: Architectural Press, 2003 ), 18.

5 Laurence C. Wu Fundamentals of Chinese Philosophy. (USA: University Press of America, Inc., 1986), 165.

6 Sarah Rossbach. Feng Shui: The Chinese Art of Placement. (New York: Penguin Books USA Inc., 1983), 161.
} 
as orientation and climate, have material associations, organ characteristics and have been an integral component in human health through its application in traditional Chinese medicine. The principles of the Five Elements, the Cycle of Balance and their role in traditional Chinese medicine, will be reinterpreted as fundamentals of sustainable design. This well be developed through a healthy and balanced built environment for a proposed recreation facility, and include improved quality of health for the users.

Chapter One establishes the theoretical premise for this thesis: beginning with the cosmological order that institutes the concept of balance and harmony with nature; forming the foundation for the subsequent discourse pertaining to the Five Elements; health; sustainability and architecture. The Chinese Five Elements and Yin Yang theories are introduced, delineating the concepts of balance and harmony. This is innately evident in their correlation with traditional Chinese medicine. The Cycle of Balance synthesizes the idea of balance and harmony and forms the premise for a critical and holistic approach for the healthy design of the proposed recreation facility. Feng shui, a traditional Chinese science, establishes a critical dialogue between the built environment and the human connection to nature.

The green building movement is introduced in Chapter Two, explaining the contemporary concept of sustainability and demonstrating that architecture has the capacity to create healthy buildings. The negative impact of the pragmatic technological approach to focus on reducing energy consumption in buildings is discussed through the concept of the sick building syndrome and in the discourse on health and architecture. The ideas and concerns raised in this chapter lead to the critical conclusion that the built environment has a significant impact on human health. This observation is linked with the theoretical premise of the Five Elements to establish the position that balance and harmony between the building and the natural environment re-establishes a connection with nature that is fundamental for achieving human health. This proposition is 
supported by the Five Element's role in balancing the health of the human in body in traditional Chinese medicine.

Chapter Three introduces the site for the proposed recreation facility - the Bayview Yards. The Bayview Yards is currently a contaminated site in need of remediation and a sensitive, healthy design strategy that incorporates the built environment with the natural environment.

In Chapter Four the Five Elements are re-introduced and, through their qualitative aspects the relationship with the program components of the proposed recreation facility are discussed.

Chapter Five investigates the Cycle of Balance as a catalyst to inform the design of the recreation facility in the massing and form of the building, in establishing a healthy built environment through a dialogue between prevailing environmental technology and a response to local environmental conditions, and the site. The Cycle of Balance is reinterpreted through the established relationships between the Five Elements and the various recreation facility program components to form sustainable, healthy design solutions for each of the interactions present in the Cycle of Balance. "Even from the narrow perspective of energy consumption, fundamental design strategies such as building orientation, location and nature of fenestration and viability of alternative energy sources (solar collection, wind generation, ground source heating) must all be closely attuned to local climate, microclimatic and geological conditions if they are to perform effectively."7

\footnotetext{
7 John McMinn and Marco Polo. $41^{\circ}$ to $66^{\circ}$ Regional Responses to Sustainable Architecture in Canada. (Cambridge, Ontario: Design at Riverside, 2006), 5.
} 


\section{Chapter 1: Traditional Chinese Culture}

\subsection{Cosmology, Architecture, and Order}

"Our architecture and other cultural artefacts unconsciously reflect ideas of cosmic order and embody our values and social reality". ${ }^{8}$ The ancients thought that it was important to create buildings in harmony with nature. Throughout history, humans have been organizing their buildings and cities based around mapping the heavens, associating celestial objects with land formations, orientating buildings with the cardinal directions, and reshaping our environment on the basis of these universal schemes. ${ }^{9}$ The creation of order in the universe is evident in many cultures: Western culture arrived at their "sacred geometry" from ancient Greek geometry, Daoist traditions consisted of working with the planet to link people and nature, the Chinese environment is built on a basis of primary scientific and cultural theories of the Chinese civilization such as cardinal directions, numbers, and organs, the renaissance introduced divine proportions into their paintings and monumental architecture, and Korean architects were concerned with understanding the landscape so their buildings did not disrupt nature. ${ }^{10}$ "Orienting a structure to a particular time and place creates a microcosm of a meaningful instant."11

Plato, in his approach to understanding and studying the universe, discusses the "wellbeing of the body, the well-being of the soul and the well-being of the whole in a single context."12 Plato argues that you cannot heal the body without understanding the soul and nature as a whole. ${ }^{13}$ The harmonious state of well-being which Plato describes in terms of the body can also be applicable to the design of the built environment. In the same sense that the body needs balance between the body, soul, and the whole of nature to be healthy, a building needs to

${ }^{8}$ Cate Bramble. Architect's Guide to Feng Shui: Exploding the Myth. (Amsterdam: Architectural Press, 2003), 7.

9 lbid., 6.

${ }^{10}$ lbid., 10.

11 bid., 10.

${ }^{12}$ Hans-Georg Gadamer. The Enigma of Health. (California: Stanford University Press, 1996), 75.

13 lbid., 115. 
embrace a harmonious state of balance between its body (physical built form), soul (intended use and meaning) and the natural environment.

In Chinese culture, the Book of Changes, developed between the Shang Dynasty and the Zhou Dynasty (1123 B.C.E.) is an ancient Chinese cosmological text that discusses the law of change and the relationship between humans and nature. ${ }^{14}$ The book explains the "observable changes in the world"15 through examining the sun, the moon, the constellations, the four seasons, and climate to understand the concept of change and motion. The Book of Changes also studies how two opposing forces interacting with each other are a source for motion and change. ${ }^{16}$ Using eight trigrams which represent, heaven, earth, thunder, wind, water, fire, mountain, and lake, the Book of Changes describes the social and natural changes that occur in the universe to create harmony and order. ${ }^{17}$

The study of the universe and order in our environment has determined the outcome of much of the built environment. Humans have always been aware of the various patterns and cycles that exist in our universe such as the lunar cycle, changing seasons, daily cycles and so forth. Recognizing these cycles are important for our existence in identifying our basic intuitions and our place in the world..$^{18}$

\footnotetext{
${ }^{14}$ Laurence C. Wu. Fundamentals of Chinese Philosophy. (USA: University Press of America, Inc., 1986), 160.

15 Ibid., 162.

${ }^{16}$ Zhang Qizhi. Traditional Chinese Culture. (Beijing: Foreign Languages Press, 2004), 55.

17 lbid. 55.

${ }^{18}$ Cate Bramble. Architect's Guide to Feng Shui: Exploding the Myth. (Amsterdam: Architectural Press, 2003), 36.
} 


\subsection{Five Elements Theory}

The theory of the Five Elements dates back to the Zhou Dynasty $\left(1122-256\right.$ B.C.E.). ${ }^{19}$ The Five Elements (wood, fire, earth, metal, water) are also known as Wu Xing. The Chinese word Xing implies "movement, action, or operation" of forces reacting against each other, therefore Wu Xing can be understood as "five actions" or "five phrases". ${ }^{20}$ "Wu Xing provides a framework for viewing the components of any system, their relationship, and the pattern of motion based on their interaction". ${ }^{21}$ The Five Elements are associated with, "processes, qualities, phases of cycles, inherent capabilities, or changing phenomena."22 They demonstrate how objects or phenomena interact and engage with each other in predictable cycles, providing a sense of order..$^{23}$

The ancients chose wood, fire, earth, metal, and water as the Five Elements because they were natural materials that could "characterize the behaviour of all natural objects and phenomena."24 The Yellow Emperor's Classic of Internal Medicine (Huangdi Neijing) is an ancient Chinese medical text that discusses the various forces that create the universe, including the Five Elements described as: "Heaven has four seasons and five elements to allow cultivation, growth, harvesting, and storing. It produces cold, heat, drought, humidity and wind. Man has five vital organs that transform the five influences to engender happiness, anger, vexation, sadness and fear." 25

The elements are associated with aspects such as time, space, matter, senses, colours, seasons, directions and many other qualitative characteristics. The correspondence of the Five

\footnotetext{
${ }^{19}$ Dominique Hoizey and Marie-Joseph. A History of Chinese Medicine. Translated by Paul Bailey. (Vancouver: UBC Press, 1993), 24.

20 Laurence C. Wu. Fundamentals of Chinese Philosophy. (USA: University Press of America, Inc., 1986), 165.

21 Cate Bramble. Architect's Guide to Feng Shui: Exploding the Myth. (Amsterdam: Architectural Press, 2003), 23.

22 lbid., 23.

23 Ibid., 23.

24 Ibid., 23.

${ }^{25}$ Dominique Hoizey and Marie-Joseph. A History of Chinese Medicine. Translated by Paul Bailey. (Vancouver: UBC Press, 1993), 24.
} 
Elements and their qualitative aspects are shown in Table 1.1 which demonstrates how the related properties form an integrated whole. The properties of the Five Elements play a significant role in many aspects of Chinese culture, including, traditional Chinese medicine, modern alternative medicines such as acupuncture, astrology, martial arts, and principles of feng shui.

Table 1.1: The Five Elements

\begin{tabular}{|c|c|c|c|c|c|}
\hline ELEMENT & WOOD & FIRE & EARTH & METAL & WATER \\
\hline $\begin{array}{l}\text { Cycle of } \\
\text { Balance }\end{array}$ & $\begin{array}{l}\text { Feeds Fire } \\
\text { Parts Earth }\end{array}$ & $\begin{array}{l}\text { Creates Earth } \\
\text { Melts Metal }\end{array}$ & $\begin{array}{l}\text { Bears Metal } \\
\text { Absorbs Water }\end{array}$ & $\begin{array}{l}\text { Collects Water } \\
\text { Splits Wood }\end{array}$ & $\begin{array}{l}\text { Nourishes Wood } \\
\text { Quenches Fire }\end{array}$ \\
\hline Compass & East & South & Center & West & North \\
\hline Direction & Upward & Upward & Stable & Inward & Downward \\
\hline Seasons & Spring & Summer & $\begin{array}{l}\text { Changing } \\
\text { Seasons }\end{array}$ & Autumn & Winter \\
\hline Planet & Jupiter & Mars & Saturn & Venus & Mercury \\
\hline Senses & Sight & Touch & Taste & Smell & Sound \\
\hline Action & Crushing & Exploding/Pounding & Crossing & Splitting & Drilling \\
\hline Organ & Liver & Heart & Spleen & Lung & Kidney \\
\hline Time & Sunrise & Noon & Between & Sunset & Midnight \\
\hline Climate & Windy & Heat & Damp & Dry & Wet \\
\hline Colour & Green & Red & Yellow & White/Gray & Blue/Black \\
\hline Motion & Expansive & Intense & Firm & Heavy & Fluid \\
\hline Material & Wood/Plants & Light & Rock/Stone & Metal & Water/Glass \\
\hline Activity & Walk & Look & Sit & Lay & Stand \\
\hline Tissue & Tendons & Arteries & Muscles & Skin & Bones \\
\hline Stages & Birth & Growth & Transformation & Harvest & Storage \\
\hline Position & Back & Right & Center & Forward & Left \\
\hline Shape & Tall/Nertical & Pointed/Triangle & Low/Horizontal & Spherical/Hard & Wavy/Reflective \\
\hline Yin / Yang & Minimum Yang & Maximum Yang & Neutral & Minimum Yin & Maximum Yin \\
\hline
\end{tabular}

This is a selective list of the qualative aspects of the Five Elements Theory. 
During the middle to late Zhou Dynasty the Five Elements theory became more than a "naturalistic explanation of the physical world; it had come to include an assumption about their close relation between natural phenomena and human affairs." ${ }^{26}$ Humans are considered to have a certain quantity of each of these elements in them. It is not necessarily a negative thing if someone is lacking in one of the elements, as long as the other elements are balanced to support it. There is said to be seventy-two different types or amounts of the elements in each person. As long as they have average amount of the elements then they are well balanced. ${ }^{27}$ The concept of equilibrium within the body and amongst the Five Elements will be substantiated on in Section 1.4, examining the correlation between the Five Elements and traditional Chinese medicine.

\subsection{Yin Yang Theory}

The Yin Yang Theory in conjunction with the Five Elements theory forms the fundamental basis for Chinese philosophy. The exact origin of Yin and Yang in Chinese history is not entirely known, however the earliest references of the concept of Yin and Yang can be traced back to the fourth century B.C.E. 28 Yin is associated with the earth, the moon, darkness, everything feminine, coldness, and passivity. ${ }^{29}$ Yang is associated with heaven, the sun, light, everything masculine, warmth, and energy..$^{30}$ In Chinese cosmology, the Book of Changes is a book of divination that includes Yin and Yang and determines that the most harmonious state is when the elements are

\footnotetext{
${ }^{26}$ Laurence C. Wu. Fundamentals of Chinese Philosophy. (USA: University Press of America, Inc., 1986), 170. ${ }^{27}$ Sarah Rossbach. Feng Shui: The Chinese Art of Placement. (New York: Penguin Books USA Inc., 1983), 162. ${ }^{28}$ Laurence C. Wu. Fundamentals of Chinese Philosophy. (USA: University Press of America, Inc., 1986), 157. 29 Dominique Hoizey and Marie-Joseph. A History of Chinese Medicine. Translated by Paul Bailey. (Vancouver: UBC Press, 1993), 24.

30 lbid., 24.
} 
united and dependant on each other. ${ }^{31}$ Although Yin and Yang are opposites, they "counterbalance and complement each other." 32

The Yin and Yang relationship can be characterized as containing opposition, interdependence, intertransformation, and dynamic balance. ${ }^{33}$ The opposition inherent in the Yin Yang relationship is derived from a state of contradiction between natural objects or phenomena. The interdependence and intertransformation is present in the Yin Yang relationship in the sense that they are able to change into each other. The dynamic balance is represented in the Yin Yang relationship through the "oscillating flux" in which they exist. ${ }^{34}$ The whole circle (Figure 1.1) is a symbol representing the harmonious relationship of Yin and Yang and embodies the ideas of opposition, interdependence, intertransformation, and dynamic balance. The dark area represents Yin and the light area represents Yang. They cross into each others hemisphere demonstrating a mutual dependence and the element of opposition that is in the center of each hemisphere is inheriting a sense of balance as both Yin and Yang coexist in one circle. ${ }^{35}$

The Five Elements are related to the Yin Yang theory through the common goal of balance and understanding nature with the

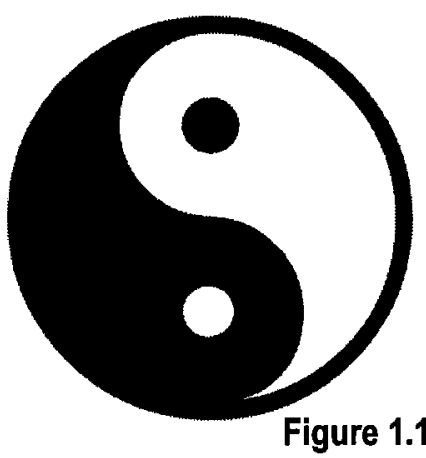
attempt to create harmonization. ${ }^{36}$ Although the Yin Yang theory and the Five Elements theory are often discussed in union, that was not always the case. Prior to 110 B.C.E. the two theories evolved separately and gradually combined ideas, forming an autonomous school of thought. ${ }^{37}$ Similar to the Five Elements, the theories of Yin and Yang use an "explanation of motion and

\footnotetext{
31 Ibid., 24.

32 Laurence C. Wu. Fundamentals of Chinese Philosophy. (USA: University Press of America, Inc., 1986), 157.

${ }^{33}$ Cate Bramble. Architect's Guide to Feng Shui: Exploding the Myth. (Amsterdam: Architectural Press, 2003), 19.

34 lbid., 19.

${ }^{35}$ Laurence C. Wu. Fundamentals of Chinese Philosophy. (USA: University Press of America, Inc., 1986), 160.

${ }^{36}$ Cate Bramble. Architect's Guide to Feng Shui: Exploding the Myth. (Amsterdam: Architectural Press, 2003), 19.

${ }^{37}$ Laurence C. Wu. Fundamentals of Chinese Philosophy. (USA: University Press of America, Inc., 1986), 158.
} 
changes in nature as its foundation", ${ }^{38}$ In ancient Chinese thought, all things are considered to contain both Yin and Yang qualitative aspects (Table 1.2) in various quantities. Having an abundance or lack of either Yin or Yang is not desired; to achieve harmony there needs to be a balance of the two elements. The properties of the Five Elements (Table 1.1) also contain various quantities of Yin and Yang which are balanced through the Cycle of Balance which is described further in this chapter.

\begin{tabular}{|ll|}
\hline Qualities of Yang & Qualities of Yin \\
\hline Above & Below \\
Intensity & Persistence \\
Back side & Front side \\
Bright & Dark \\
Day & Night \\
Dry & Wet \\
East & West \\
Expand & Contract \\
Fast & Slow \\
Features of landscape & Retained water \\
Fire & Water \\
Fly & Walk \\
Function & Structure \\
Generate & Grow \\
Hard & Soft \\
immaterial & Material \\
Intentionality & Passivity \\
Left & Right \\
Noisy & Quiet \\
Noon & Midnight \\
North of the ecliptic & South of the ecliptic \\
Outside & Inside \\
Produce Energy & Produce form \\
Qi' & Fluids \\
Rapid & Gradual, lingering \\
Restive & Still \\
Rise & Descend \\
Round & Flat \\
Smooth & Rough \\
South & North \\
Summer solstice & Winter solstice \\
Sun & Moon \\
Time & Space \\
\hline & \\
\hline & \\
\hline
\end{tabular}

Table 1.2:

Yin and Yang Qualities

'Qi can refer to the activity of life (and to the traditional mind life is an aspect of being). It can also refer to mood or an active influence (perhaps something auditory, atmospheric, bacterial, viral, or chemical). In Chinese science, numbers along with principles and qi describe and direct how nature functions.

${ }^{38}$ Cate Bramble. Architect's Guide to Feng Shui: Exploding the Myth. (Amsterdam: Architectural Press, 2003), 19. 


\subsection{Correlation Between the Five Elements and Traditional Chinese Medicine}

The Five Elements and Yin and Yang provided a fundamental theoretical foundation for the development of traditional Chinese medicine. ${ }^{39}$ These theories were further developed sometime between 770 - 746 B.C.E. in the Yellow Emperor's Classic of Internal Medicine (Huangdi Neijing); China's first classic book of medicine, covering traditional Chinese medicine and health-science..$^{40}$ The book was a compilation of essays from various physicians over a series of eighteen volumes written during the Warring States period (1100 - 221 B.C.E.) and contains both repetitions and contradictions of theories. ${ }^{41}$ The questions posed in the book by the Yellow Emperor and his advisors engage many aspects of the known scientific knowledge of philosophy, astronomy, geography, and biology. ${ }^{42}$ The final version of the Yellow Emperor's Classic of Internal Medicine was thought to most likely not be completed until sometime in the Western Han Dynasty (206 B.C.E. -25 C.E.). ${ }^{43}$ One of the significant achievements of this book was the introduction of Yin and Yang and the Five Elements into a unified theory of medicine, acknowledging them as essential components influencing Chinese medical tradition. ${ }^{44}$

A new doctrine on the Motion of the Five Elements and Six Natural Factors was established in 618-907 C.E. and discussed how the Five Elements (wood, fire, earth, metal, and water) and the Six Natural Factors (wind, heat, mildness, fire, dryness, and cold) are important to determining the development of disease. 45 The theory that supported this doctrine was based on a conviction that many diseases and their related treatments are linked to environmental conditions, including

${ }^{39}$ Dominique Hoizey and Marie-Joseph. A History of Chinese Medicine. Translated by Paul Bailey. (Vancouver: UBC Press, 1993), 23.

40 Zhang Qizhi. Traditional Chinese Culture. (Beijing: Foreign Languages Press, 2004), 218.

${ }^{41}$ Dominique Hoizey and Marie-Joseph. A History of Chinese Medicine. Translated by Paul Bailey. (Vancouver: UBC Press, 1993), 27.

42 lbid., 27.

43 lbid., 27

${ }^{44}$ Zhang Qizhi. Traditional Chinese Culture. (Beijing: Foreign Languages Press, 2004), 218.

45 Ibid., 220. 
climate and seasons. ${ }^{46}$ The Motion of the Five Elements and Six Natural Factors doctrine and its supporting theory are important as it led to the development of various treatment methods and principles.

The ideas that are raised in the doctrine on the Motion of the Five Elements and Six Natural Factors regarding the link between diseases and environmental conditions are also valid concerns in modern health. This relationship between human health, the environment, and establishing a harmonious balance in the current era will be further discussed in Chapter Two.

\subsection{Cycle of Balance}

The Cycle of Balance synthesizes the concept of balance that was discussed in the Yin Yang Theory and the Five Elements theory through the interactions of the Five Elements. Since the Five Elements consist of properties of materials (Table 1.1) they are susceptible to taking part in cycles of change. This is a dynamic exchange and interaction where the elements alternately create and destroy each other.

The order in which the elements appear can vary. The "mutual production order", which is wood, fire, earth, metal, and water, is the order in which the elements create each other. ${ }^{47}$ The interaction phases of the creation cycle, also known as the generating cycle is as follows:

Wood feeds Fire.

Fire creates Earth.

Earth bears Metal.

Metal collects Water.

Water nourishes Wood.

$46 \mathrm{lbid} ., 221$.

${ }^{47}$ Laurence C. Wu. Fundamentals of Chinese Philosophy. (USA: University Press of America, Inc., 1986), 166. 
This order relates to the successive seasons of the year allotted to each element, as well as the directions associated with each element. "Wood appears in spring (East), fire appears in summer (South), metal appears in autumn (West), and finally water appears in winter (North)". ${ }^{48}$ Earth is considered to engage the center position within the Five Elements and the associated cycles.

The other cycle of balance is the "mutual conquest order", which is wood, metal, fire, water, and earth. The mutual conquest order is the order in which the elements destroy each other. The interaction phases of the destruction cycle also known as the overcoming cycle is as follows:

Wood parts Earth.

Earth absorbs Water.

Water quenches Fire.

Fire melts Metal.

Metal splits Wood.

The Cycle of Balance is used to explain the forces of the Five Elements reacting against each other. This relationship is illustrated in Figure 1.2. If each successive phase of the cycle is followed, then in the process of change, balance and order will be achieved. The elements need to be in balance and cannot allow for one element to be over abundant. This can be explained in the two additional cycles which exist; the cycles of imbalance which include an overacting cycle and an insulting cycle. However the primary cycles and the most relevant cycles for this thesis are the cycles of balance. The cycles of imbalance do not engage in dynamic interactions between phenomena. Rather they indicate that an abundance of one element can overact or insult another element.

48 lbid., 167. 


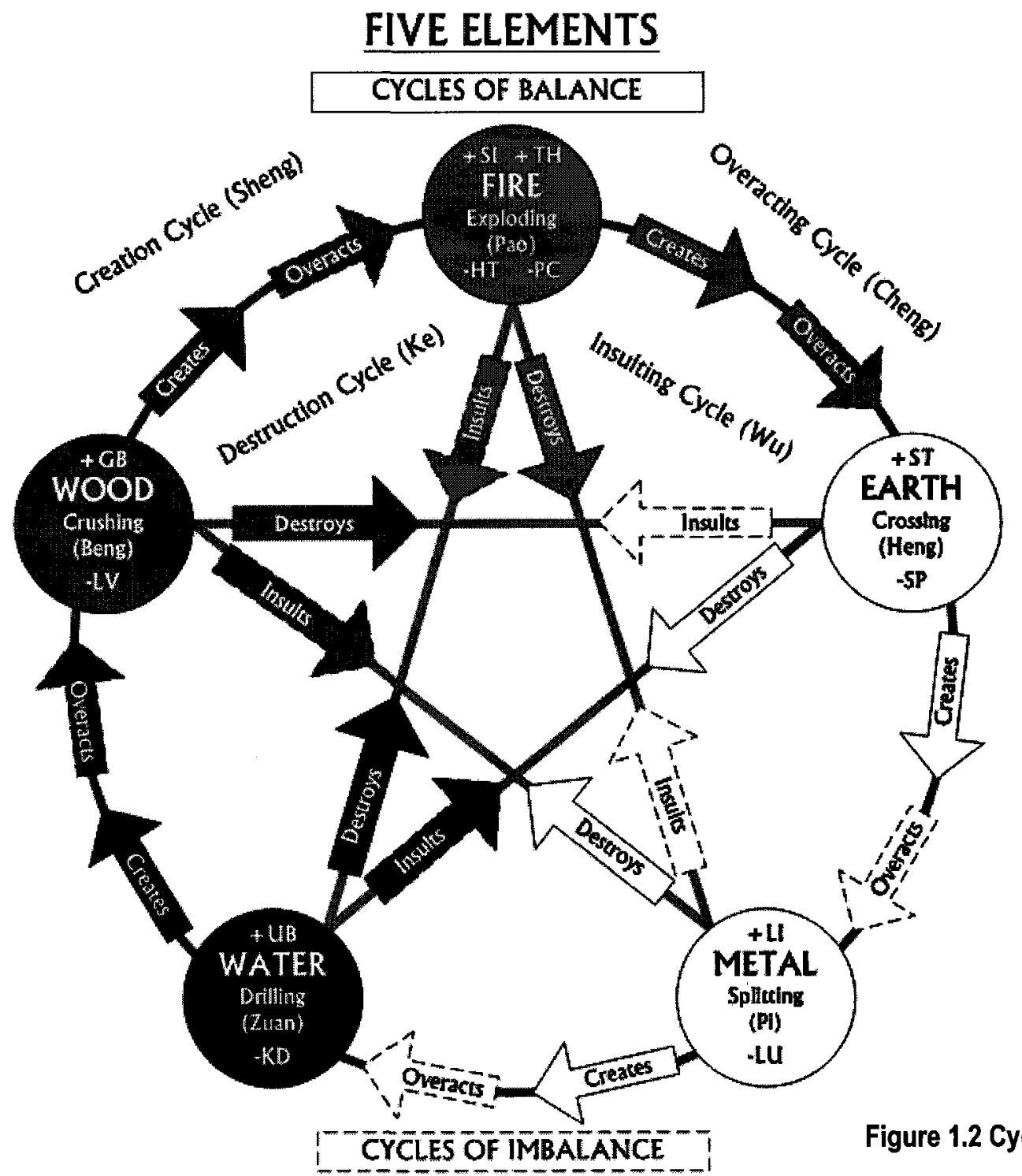

Figure 1.2 Cycle of Balance

In the Cycle of Balance, the various phases of interaction between the Five Elements also successfully address the Yin Yang Theory of balance. The combination of the elements in each phase balance each other as they each inherit opposite quantities of Yin and Yang. For example, in the generating cycle: water nourishes wood - water contains max Yin while wood contains increasing Yang. Ultimately equilibrium is created between the two elements. 


\subsection{Feng Shui}

Feng shui is a component of traditional Chinese science, literally translating as "wind" and "water", which basically "can be understood as an attempt to re-establish a dialogue between humanity's deepest needs and our long-estranged, much-abused planet". ${ }^{49}$ Feng shui is a science that has increased in interest in the last century, mainly in interior design, but can be traced back as far as fourth century B.C. 50 Feng shui "follows a long history of interactions and knowledge of the world-empirical knowledge built up over generations and grounded in practical evidence". .51

Feng shui incorporates the Yin and Yang and Five Elements theories. It is important to work with nature and acknowledge natural cycles. ${ }^{52}$ The Five Elements are associated with various properties and characteristics of nature and can be used to demonstrate "ecological techniques for approaching and appreciating nature". ${ }^{53}$ Feng shui evolved based on the concept that people are affected by their surrounding environment and that a harmonized environment would provide health, prosperity, and good luck.54 "The aim of feng shui, then, is to change and harmonize the environment." ${ }^{55}$ Similar to the Cycle of Balance, a feng shui practitioner would incorporate the characteristics and qualitative aspects of the Five Elements and Yin and Yang, to engage, correlate, and interact with various objects or phenomena to achieve positive energy flow and harmony. "Despite its pragmatic aspect, feng shui is in a sense a rosetta stone linking man and his environment, ancient ways and modern life."56

\footnotetext{
${ }^{49}$ Cate Bramble. Architect's Guide to Feng Shui: Exploding the Myth. (Amsterdam: Architectural Press, 2003), 13.

${ }^{50}$ Sarah Rossbach. Interior Design with Feng Shui. (New York: Penguin Books USA Inc., 1987 ), 7.

${ }^{51}$ Cate Bramble. Architect's Guide to Feng Shui: Exploding the Myth. (Amsterdam: Architectural Press, 2003), 14.

52 lbid., 86.

53 lbid., 19.

${ }^{54}$ Sarah Rossbach. Feng Shui: The Chinese Art of Placement. (New York: Penguin Books USA Inc., 1983), 2.

55 lbid., 2.

56 Ibid., 4.
} 
"Traditional methods of feng shui supply a creative problem-solving system to analyze the built and natural environments and to better understand and improve the quality of life.".57 These principles of feng shui complement traditional concepts of sustainability and will be further examined in the subsequent chapter and integrated into this thesis project, which aims to improve the quality of life through creating a sustainable, healthy architecture.

"The Chinese felt they shared a fate with the earth: When it was healthy and prospered, they thrived; when the balance was destroyed, they suffered. So it made sense, in feng shui terms, to enhance the environment rather than to harm or deplete it, thus hurting the chances for good luck and happiness." 58

${ }^{57}$ Cate Bramble. Architect's Guide to Feng Shui: Exploding the Myth. (Amsterdam: Architectural Press, 2003), 13.

${ }^{58}$ Sarah Rossbach. Feng Shui: The Chinese Art of Placement. (New York: Penguin Books USA Inc., 1983), 8. 


\section{Chapter 2: Sustainability and Healthy Design}

\subsection{Green Building Movement}

"The green building movement is guided by a simple, yet revolutionary, idea that the buildings in which we live our lives can nurture instead of harm, can restore instead of consume, and can inspire instead of constrain." ${ }^{\text {"59 }}$

The green building movement and sustainable design approaches have not always been a priority. The oil crisis in 1973 triggered change in the modern thinking and approach to the energy conservation standards in the design of the built environment. 60 The attempt to reduce energy consumption resulted in buildings that obtained higher insulation values and lower ventilation rates, which over a period of time led to greater problems such as the 'sick building syndrome' which will be further detailed in the following section. ${ }^{61}$

"Design professionals soon recognized and accepted responsibility for the connection between specifications and building practices on the one hand and the long-term health of building occupants and the environment on the other hand." ${ }^{" 62}$ The built environment has been changed by globalization and there is a growing concern for the future of the environment in which we live. "This fact alone constitutes a challenge to the architectural profession at large: to acknowledge its collective responsibility in meeting the environmental challenges of today to secure a more sustainable future for the generations of tomorrow".63 David Suzuki, a supporter of the green building movement argues that, "we are forced to live in a finite world, that there are limits beyond

${ }^{59}$ Robin Guenther and Gail Vittori. Sustainable Healthcare Architecture. (New Jersey: John Wiley \& Sons, Inc., 2008),xiii

60 Peter Busby and Jim Taggart. Busby: Learning Sustainable Design. (Quebec: Janam Publications Inc., 2007), 124.

61 lbid., 124.

62 lbid., 124.

63 lbid., 13. 
which we cannot go if we are to have a truly sustainable future." ${ }^{64}$ There is a need and demand for architecture that fosters a sustainable approach.

The green building movement initiated several programs, guidelines, tools, plans, and incentives to create a healthier built environment. Most notably, the Leadership in Energy and Environmental Design (L.E.E.D.) program was a catalyst for the popularization of the green building movement and was developed as a measurement tool that has "emerged to provide standardized reference systems and methods of evaluation."65 This thesis endorses the concerns about healthy buildings that have resurfaced in architectural design via the green building movement.

\subsection{Healthy Buildings and Sick Buildings}

Sick building syndrome (SBS) is a term that was developed by the World Health Organization (WHO) in the early 1980 's to define human health problems that were caused by unhealthy environments within buildings. ${ }^{66}$ An increasing number of complaints by building inhabitants regarding a multitude of symptoms related to time spent in a particular interior environment led the World Health Organization to form a panel to discuss the issues. "A sick building is distinguished from a normal one, under the WHO definition, by the prevalence of symptoms; that is, a large percentage of the occupants report symptoms. More than $30 \%$ of new buildings would be sick buildings according to WHO."67

The World Health Organization determined that many of the common symptoms of sick building syndrome include headaches, cough, dizziness, nausea, eye, nose, throat, and skin

\footnotetext{
64 Ibid., 4.

65 lbid., 110.

${ }^{66}$ Thad Godish. Sick Buildings: Definition, Diagnosis and Mitigation. (USA: CRC Press Inc. 1995), 1.

67 Ibid., 2.
} 
irritations. ${ }^{68}$ It was deemed that most of these symptoms were related to the building since most occupants were relieved of their symptoms upon leaving the building environment. Not all of the identified symptoms may have a specific cause; however there are some identifiable causes for human health problems in buildings. Most of the human health issues relate to a general problem of poor indoor air quality (IAQ).69 Poor indoor air quality occurs most often in climate-controlled environments and include factors such as, "insufficient ventilation or thermal control, inadequate maintenance of building systems, changes in thermal or contaminant loads, changes in building operation to meet new objectives such as energy conservation, and inadequate design. ${ }^{770}$ In addition to the indoor air quality problems mentioned, lighting is also often an issue, affecting human comfort. Most people are more comfortable with and would prefer natural day lighting over fluorescent lighting in many instances. Inadequate lighting conditions due to either lack of lighting or excessive lighting can also contribute to some of the common sick building syndrome symptoms such as headaches and eye strains. ${ }^{71}$

There is a common concem for healthy environments. Understanding and identifying the causes of sick building syndrome will play an influential role in the design of the proposed recreation facility of this thesis. "Several interrelated strategies can be employed to achieve this goal, such as maximizing daylight penetration while controlling solar heat gain, providing operable windows and configuring the building to facilitate natural ventilation and using the thermal mass of the structure to absorb and re-radiate heat as required."72 In addition, careful consideration of materials which do not give off volatile organic compounds (VOCs) is of utmost concern.

$68 \mathrm{lbid} ., 2$.

69 lbid., 1.

70 lbid., 3.

71 bid., 60.

72 Peter Busby and Jim Taggart. Busby: Leaming Sustainable Design. (Quebec: Janam Publications Inc., 2007), 10. 


\subsection{Health and Architecture}

"Buildings are human habitat. The way we design, construct, and operate these buildings has a profound impact on our health and the health of the environment."73 Human health is not always defined as an absence of disease; according to the World Health Organization (WHO) it is also determined by a person's physical, mental, and social well-being. ${ }^{74}$ It has been proven that there are many variables in the physical environment that influence the health and well-being of humans. The most common ones include environmental issues such as temperature, humidity, daylight, and acoustic levels. ${ }^{75}$ "The people who live, work, learn, and heal in healthy buildings are healthier, happier, and more productive."

The changing environmental conditions in the twenty-first century have increased the importance for designing a "healthy" built environment as "buildings are the physical manifestation of values and a means to communicate just what those values are."76

Good health requires a harmonious relationship consonant with both our social and our natural environment. It is this harmony which first enables us to move in accord with the natural rhythms which govern our bodily life. This is the case, for example, with the rhythm of breathing or with the cycle of sleeping and waking. Is the facility for collecting data which is so prized by modern science really adequate for grasping phenomena such as these?77

The notion that the body requires balance and harmony with the natural environment is analogous to the design of a "healthy" building. The natural rhythm of breathing is an important factor for buildings as well as other connections with the cycles of nature such as light. The idea of 'collecting data' in modern science which is questioned in the previous passage is suggestive of the role of technology in health. The same extent of questioning is applicable for examining the

\footnotetext{
${ }^{73}$ Robin Guenther and Gail Vittori. Sustainable Healthcare Architecture. (New Jersey: John Wiley \& Sons, Inc., 2008),xiii.

74 lbid., 25.

75 lbid., 17.

76 bid., xvii.

77 Hans-Georg Gadamer. The Enigma of Health. (California: Stanford University Press, 1996), 132.
} 
adequacy of some modern technical building solutions such as mechanically climate-controlled buildings versus establishing climate-controlled buildings through engaging in a harmonious relationship with nature.

"Being attentive to sustainability, wellness, and resource stewardship presents a holistic view of healthcare that has an impact. We may not be able to measure or test it, but I'm convinced it has a tremendous impact on a person's ability to attain health. Not just to be not sick, but to be in health. ${ }^{78}$

${ }^{78}$ Robin Guenther and Gail Vittori. Sustainable Healthcare Architecture. (New Jersey: John Wiley \& Sons, Inc., 2008),263. 


\section{Chapter 3: The Site}

\subsection{Introduction}

The project will be situated on the Bayview Yards site in Ottawa. This inner-city site is located just west of Ottawa's downtown core, with the Ottawa River to the north, the developing upper-middle class community of Lebreton Flats to the east, the existing working class communities of Mechanicsville, Little Italy, and Hintonburg to the south and west, and Tunney's Pasture, an area populated with federal govemment buildings lies to the far west. A number of environmental assessments have been executed, determining that the 14-acre Bayview Yards site is currently a contaminated brownfield 79 .

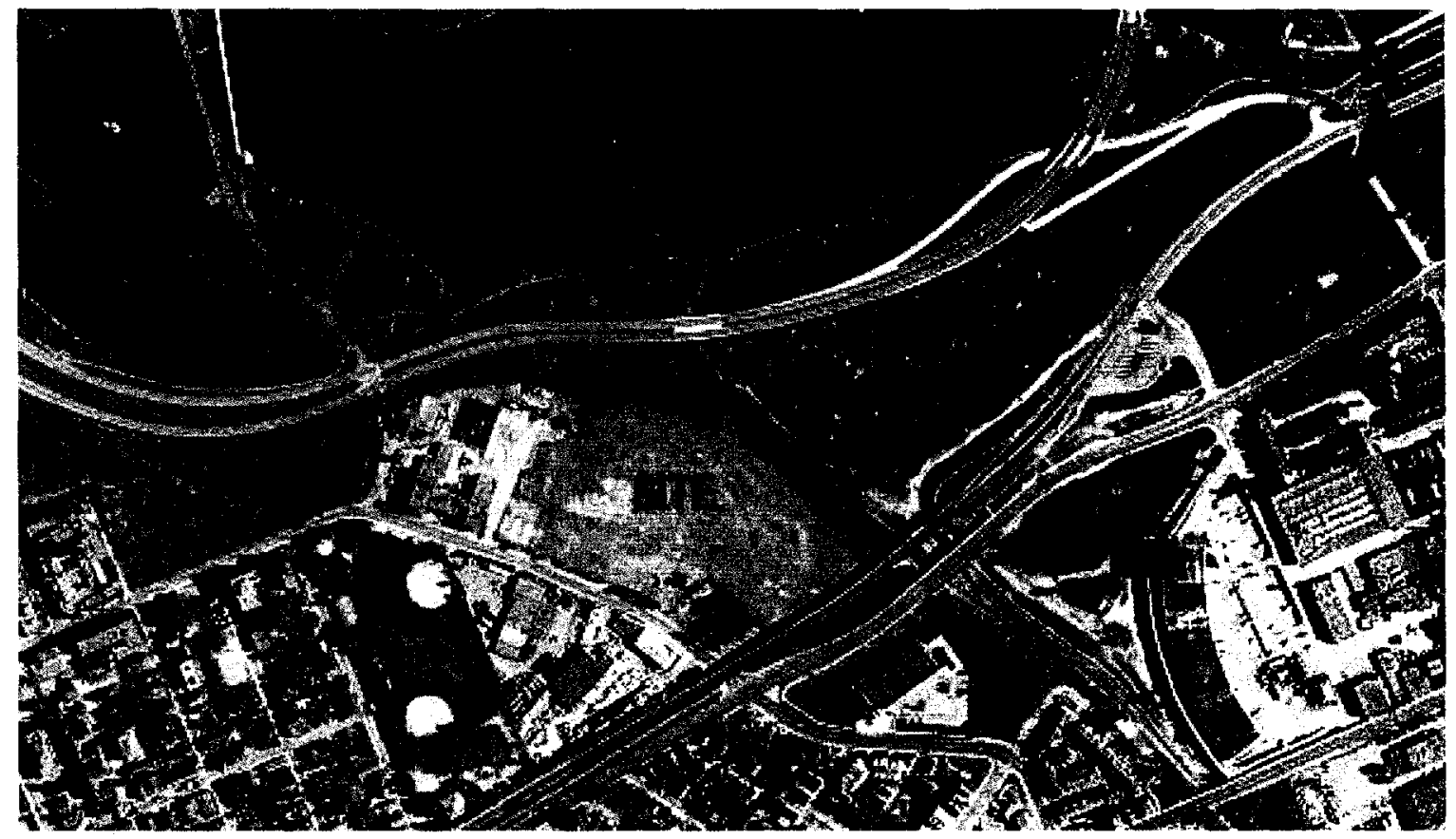

Figure 3.1: Aerial View of Bayview Yards

${ }^{79}$ Brownfield: Abandoned, vacant, derelict or underutilized commercial and industnal properties where past actions have resulted in actual or perceived contamination; brownfields differ from other contaminated sites in that they hold active potential for redevelopment

National Roundtable on Environment and Economy (NRTEE)

The City of Ottawa. The Brownfields Context, 2008

$<$ <ttp://www.ottawa.ca/residents/planning/brownfields/introduction/context_en.html> (accessed November 2007). 


\subsection{History}

During the 1900's the site was crowded with rail lines to support the lumber industry that began in the Ottawa valley in the early 1800 's. ${ }^{80}$ The great fire of 1900 (April 26), devastated the city of Ottawa, with Lebreton Flats and the Bayview Yards being the regions hardest hit. ${ }^{81}$ The entire area was completely wiped out from the fire. The area was rebuilt and the railway remained on the Bayview Yards site to support the metal industry that took over after the great fire. In 1963 the NCC expropriated the land at Lebreton Flats and demolished all existing infrastructure. With the existing community at Lebreton Flats torn down and the lumber and metal industries at the site abolished, the railway at the Bayview Yards site was no longer required and the site was abandoned.

\subsection{A Contaminated Site}

"When a community is wiped off the map, the map is never wiped clean. The acre's blackboard was blank, the traces of the lives that crossed it were gone; but they left their dusty mark." ${ }^{\prime 2}$ In the years following the NCC's expropriation of land, environmental assessments commenced. The areas previous industrial uses have contaminated the land. As early as the 1860's the residents began to react to the pollution of the river; having evidence of the contamination caused by industry. ${ }^{83}$ The scrap yards from the various metal industries left behind waste material and storage facilities that contained petroleum and other hazardous chemicals. ${ }^{84}$

\footnotetext{
${ }^{80}$ Phil Jenkins. An Acre of Time. (Toronto: Macfarlane Walter \& Ross, 1996), 124.

81 lbid., 151.

82 lbid., 207.

83 Ibid., 208.

84 lbid., 209.
} 
As a result, "the most significant environmental impact related to the redevelopment of Lebreton Flats/Bayview concerns the contamination of soils and groundwater throughout." 85

\subsection{Current Conditions}

The Bayview Yards site is currently being used by several City of Ottawa operations, (including a snow dump) until future development plans are introduced. The site is located at a major transportation hub in the city with the Bayview O-Train station and Bayview Transitway stop located adjacent to the site. The future proposals for the Ottawa O-Train include extending the OTrain north from this site into Gatineau and forming an east/west line connecting with the Bayview station. The site can also be reached from Bayview Road, on the east side of the site, and the Ottawa River Pathway system to the north of the site. In addition to being located at a major transportation hub, the site is also situated adjacent to many recreation areas. The Tom Brown Arena is located to the south of the site on Bayview Road, to the east of the site is Laroche Park, and to the north are recreation paths and a kayak training course located respectively alongside and in the Ottawa River. The lands adjacent to the site are occupied by the National Capital Commission, Lemieux Island Water Filtration Plant, Merkley Supply, Tom Brown Arena, and Laroche Park.

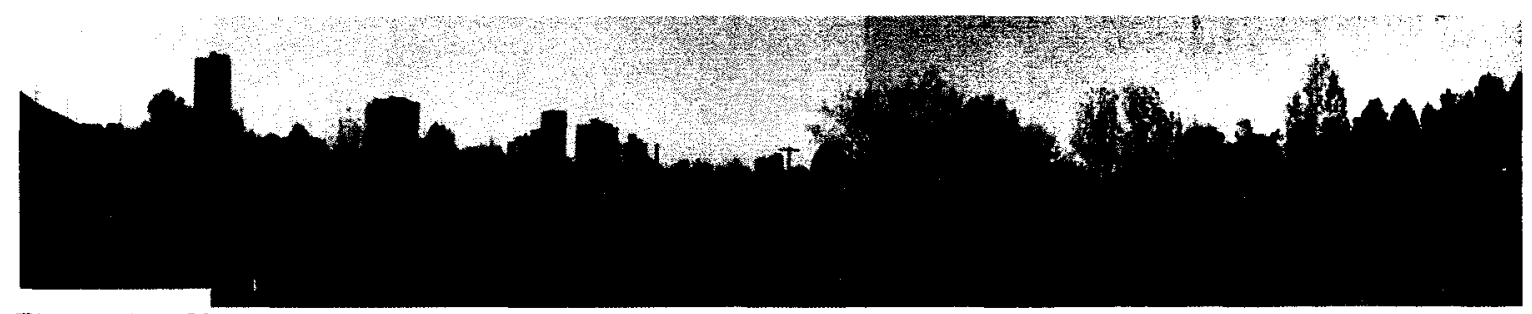

Figure 3.2: Site

85 Ibid., 209. 


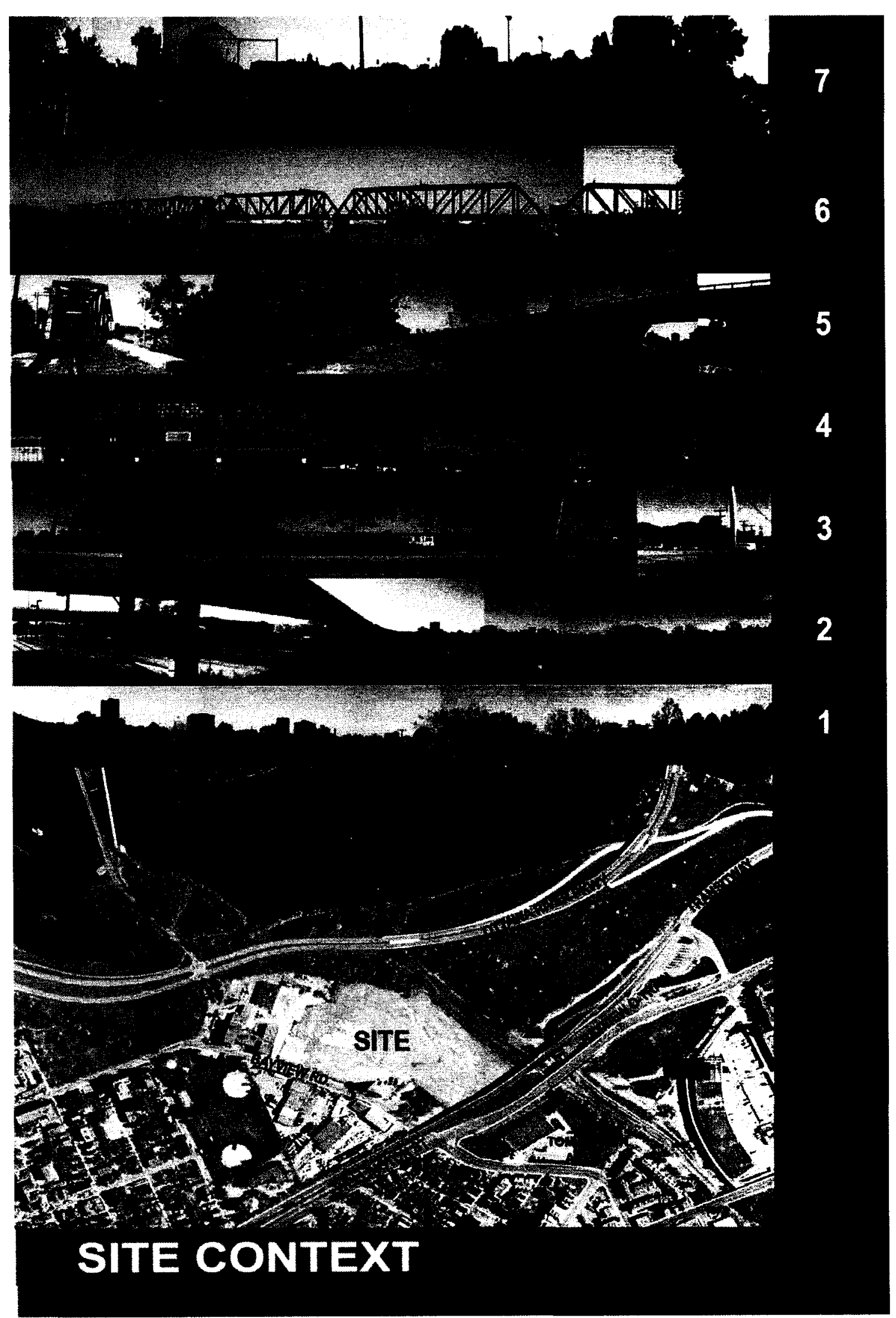

Figure 3.3: Site Context Images and Current Site Plan 


\subsection{Development Proposals}

Currently there are several development proposals for the Bayview Yards site. The Bayview Yards site is situated in a location where it is easily accessed by rail, bus, car, bicycle, and pedestrians. The official plan has designated the Bayview Yards site as a place of residential or mixed-use programs. ${ }^{86}$ The plan also proposes "an approach to collaborative community building that emphasizes shared values and mutual obligation and builds trust and responsibility within the community". ${ }^{87}$ Former Ottawa mayor, Bob Chiarelli proposed that the Bayview yards site be transformed into a "mini Central Park".88 His proposal would have developed the site into an urban green space for outdoor recreation and sports, recreation facilities, and a place for community arts. Other proposals include developing the site to become the home for a new city library in combination with residential and commercial buildings.

Keeping mind the intentions

set forth by the official plan to create

a "collaborative community building"

and Chiarelli's vision for the Bayview

Yards site; the proposed recreation

facility for this thesis will be a viable

project, satisfying the previously

established visions for the site.

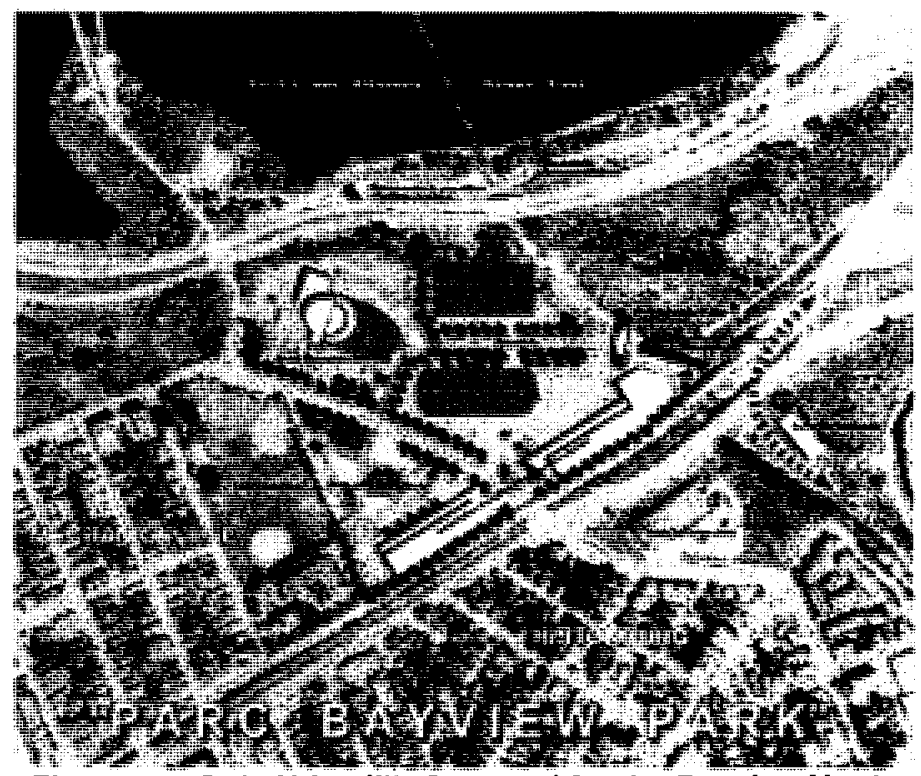

Figure 3.4: Bob Chiarelli's Proposal for the Bayview Yards

\footnotetext{
86 Diane Holmes. New Developments, 2007, <http:/wwww.dianeholmes.ca/new_developments_detail.php?id=31> (accessed October 2007).

${ }^{87} \mathrm{lbid}$.

${ }^{88}$ Sarah O'Donoghue, "Chiarelli has a Green Plan for Bayview Yards," (Ottawa Citizen, November 9, 2006), $\mathrm{http}: / / w w w . c a n a d a . c o m / o t t a w a c i t i z e n / f e a t u r e s / m u n i c i p a l e l e c t i o n s 2006 /$ story.html?id=db9b5e3e-bd64-4d7f-a828fd336e51f3da\&k=52123 (accessed September 2007).
} 


\section{Chapter 4: Program and Five Elements Theory}

\subsection{Program}

A recreation facility will serve as the catalyst for healthy living and wellness, targeting the diverse range of potential users. The facility will provide a place of recreation, therapy, education, relaxation, and health for the residents of all ages and people employed in the surrounding neighbourhoods. The Bayview Yards site is a suitable site for the program of a recreation facility. It is located at a major transit hub within the city, and in close proximity to other recreational activities and programs.

\subsection{The Five Elements Correlated to the Design of a Recreation Facility}

In traditional Chinese medicine there is an equilibrium required among the Five Elements and also between Yin and Yang. The health of a person is dependant on this balance. "All activities in daily life, food, spiritual regulation, physical exercise, and administration of drugs must have the purpose of balancing the two aspects" ${ }^{89}$ This thesis demonstrates how a "healthy building' can be designed according to the principles of the Chinese Five Elements.

The program components of the recreation facility are divided into five categories; with each program component being associated with one of the Five Elements. The various program components of the recreation facility are divided into the following categories: 1. "Wet" Activities; 2. "Dry" Activities; 3. Healing and Therapeutic Activities; 4. Common Spaces; and 5. Office, Administration, and Support Spaces. Table 4.1 lists the program components associated with each of these categories.

${ }^{89}$ Zhang Qizhi. Traditional Chinese Culture. (Beijing: Foreign Languages Press, 2004), 235. 


\begin{tabular}{|l|l|l|l|l|}
\hline "Wet" Activities & "Dry Activities" & $\begin{array}{c}\text { Healing and } \\
\text { Therapeutic } \\
\text { Activities }\end{array}$ & \multicolumn{1}{|c|}{$\begin{array}{c}\text { Common } \\
\text { Spaces }\end{array}$} & Support Spaces \\
\hline Lap Pool & Gymnasium & Spa & Lobby/Lounge & Offices \\
\hline Diving Pool & Squash Courts & Therapeutic Pool & $\begin{array}{l}\text { Change Room / } \\
\text { Locker Room }\end{array}$ & Classrooms \\
\hline Children's Pool & Indoor Track & Hot Tub & Restaurant/Café & Meeting Rooms \\
\hline Showers & Fitness Centre & Sauna & Rental Store & Washrooms \\
\hline & Tennis Courts & Physiotherapy & Retail Store & Storage \\
\hline & & First Aid Room & Link to O-Train & Housekeeping \\
\hline & & & & $\begin{array}{l}\text { Mech./Elect. } \\
\text { Rooms }\end{array}$ \\
\hline
\end{tabular}

Table 4.1

The categorization of the program components is based on similar use and purpose. This determines which of the Five Elements each program category forms a relationship with. The process of associating the program with the Five Elements was based on a hierarchy of taking the most prominent program category, based primarily on physical size and the extent of use of the program, and associating it with the element that is the most compatible match and continuing with this process until each of the program and element relationships were determined.

The qualitative aspects and properties associated with each of the Five Elements are the determining factors for establishing the relationship between the program and its most compatible element.90 Additionally, the qualitative aspects associated which each element will determine the materiality of each program space. These relationships and material conditions are described in the following sections. The order in which the relationships are discussed follows the hierarchy previously mentioned.

\footnotetext{
${ }^{90}$ Relating the program to a corresponding element is based on finding the element which has the most compatible qualitative aspects and properties with the particular program category and simultaneously the program does not need to be compatible with all of the element's qualitative aspects and properties.
} 


\subsection{Water: "Wet" Activities}

A large component of the recreation facility is the salt water swimming pools, which include an Olympic size lap pool, a diving pool with a built in diving platform structure, and spectator seating. A children's recreation pool is integrated into the program and includes a zero entry ramp and a view overlooking the city. The three swimming pools, as well as the showers within the change rooms all have the aspect of water in common and form the "wet" activities category.

The "wet" activities are correlated to the water element. The compatible qualitative aspects of the water element include:

\section{Season: Winter \\ Motion: Fluid \\ Material: Water and Glass \\ Yin / Yang: Max Yin}

Climate: Cold

Shape: Wavy and Reflective

Organ: Kidney

The season of winter is relevant since indoor pools are primarily used in the winter season. The climatic qualitative aspect is cold, which is associated with the water temperature in the swimming pools. The aspects of fluidity, wavy, and reflective are analogous of the movement and properties of water. The kidney is associated with the "wet" activities, and its main purpose is to balance, regulate and filter bodily fluids, similar to the necessity of the swimming pools to balance, regulate, and filter the water. The water element contains Yin qualities which are related to the "wet" activities and include: wet, retained water, inside, and fluids.

The materiality associated with the "wet" activities is water and glass. The structure for this portion of the building is steel. The majority of the exterior façade of the swimming pools is glass curtain wall, allowing for passive solar gain to contribute to maintaining a comfortable water temperature as well as providing a view from the third level recreation pool to the adjacent landscape and downtown Ottawa in the distance. 


\subsection{Fire: "Dry" Activities}

Another primary component of the proposed recreation facility is the "dry" activities. These include all of the other principal physical recreation components such as the gymnasium, fitness centre, squash courts, tennis courts, and an indoor track. The gymnasium accommodates a full size basketball court, two half size basketball courts, a full size volleyball court, three half volleyball courts, badminton courts, and spectator seating on two levels.

The "dry" activities are correlated to the fire element. The compatible qualitative aspects of the fire element include:
Compass Point: South
Motion: Intense
Season: Summer
Climate: Heat
Action: Pounding/Exploding
Organ: Heart
Material: Light
Yin / Yang: Max Yang

The qualitative aspects of the fire element such as summer, south, light, intense, and heat all suggest the notion of heated, intense, and sweaty cardiovascular activities, which also relates to the organ, the heart. Physical activities such as squash, tennis, badminton, basketball, and volleyball can be associated with the actions of pounding and exploding. The fire element also contains Yang qualities which relate to the "dry" activities and include: intensity, dry, fast, noisy, rapid, south, sun, and time.

The materiality of the fire element spaces are based on the qualitative aspects of light and heat. The most notable material is the black corrugated metal attached to the concrete wall on the south facade. The black corrugated metal in conjunction with the mass of the concrete wall, absorb heat, benefiting from passive of solar gain. The structure and other walls of the "dry" activity spaces are concrete with glazed openings in selected areas. The materials selected allow the building to either transmit light or absorb heat, both qualitative aspects of the fire element. 


\subsection{Earth: Healing and Therapeutic Activities}

In addition to the typical recreation components, the proposed recreation facility is also incorporating a healing and therapeutic element to the program, which will include a day spa, physiotherapy, hot tub, sauna, therapeutic pool, and also the first aid areas. As important as promoting physical activities is, it is equally important to acknowledge the healing and therapeutic aspects that affect and influence the health of a person.

The healing and therapeutic activities are correlated to the earth element. The compatible qualitative aspects of the earth element include:

Compass Point: Center

Climate: Damp

Organ: Spleen

Material: Rock, Brick, Ceramic, Concrete
Season: Change of Seasons

Action: Crossing

Yin Nang: Neutral

Earth is associated with the changing of seasons, an annual transformation, similar to the notion that when a person is healing they also undergo transformations, never remaining static. The action correlated to the earth element is crossing. This is evident where the various healing and therapeutic program components overlap and crossover with some of the other programs. For example, the physiotherapy component closely relates to the fitness centre both in physical location and in use and similarly the therapeutic pool closely relates to the swimming pools. The earth element is a central component crossing over both the "wet" and "dry" activities, perceptually balancing these two conditions climatically in the form of dampness, while simultaneously satisfying the Yin Yang qualitative aspect of neutral. The spleen is also associated with the earth element. The spleen is part of the immune system; it filters blood through the destruction of old blood cells, and contains nodules that assist in fighting infection. The primary purpose of the spleen is related to the objectives of the healing and therapy, which are to restore to health in the human body. 
The materiality in the earth spaces consist of natural materials such as rock, brick, ceramic, concrete, and rammed earth. The majority of the walls in the healing and therapeutic spaces are rammed earth left in its natural state. The structure of the earth spaces is concrete. The quality of the rammed earth's rough textures and warm hues in contrast with the polished concrete floor are very sensual and appropriate for a spa which is largely about varying sensual experiences and natural and "healthy" materials.

\subsection{Wood: Common Spaces}

The common spaces of the recreation facility include public spaces such as the three primary entrances and lobbies, the corridor link to the O-Train station, circulation spaces, equipment rental and retail space, the restaurant and café, and the private common space of the locker and change rooms which are in two locations that are in close proximity to all of the program components they serve.

The common spaces of the recreation facility are correlated to the wood element. The compatible qualitative aspects of the wood element include:
Compass Point: East
Season: Spring
Shape: Tall and Vertical
Motion: Expansive
Climate: Windy
Organ: Liver
Material: Wood and Plants
Yin / Yang: Increasing Yang

The qualitative aspects of the wood element such as east and spring communicate the notion of beginning. Similarly the common spaces of the entries and lobbies are the beginnings or arrival points into the recreation centre, just as the locker and change rooms are utilized prior to commencing a recreation activity. The public spaces of the recreation center accommodate large crowds, allow for visual connections between the program components, and provide spacious and open circulation systems in the facility. For these reasons the tall, vertical, and expansive 
qualitative aspects are relevant. The climate condition for the wood element is windy, which is associated with air and the notion of breathing and will be addressed in the form of natural and cross ventilation. The wood element also has Yang qualitative aspects which are correlated to the common spaces and include: east, expand, function, generate, noisy, and restive. The restive aspect of Yang, is addressed in the seating areas located near the lobbies and along the circulation routes. The wood element is related to the liver. The entrances, lobbies, and circulation spaces function similarly to the liver in that they are breaking down and separating the various components of the recreation facility just as the liver breaks down the nutrients from food digestion. In the same sense the locker and change room breaks down the it's internal components into lockers, changing areas, showers, and washrooms, separating areas based on their function and level of privacy required.

The materials associated with the wood elements are wood and plants. The structure of most of the common spaces will be comprised of wood columns and glue-laminated beams. The Pine trees in the courtyard align with this structure. Pinewood will be used for the wall paneling and provides a familiar smell of the outdoors, perceptually connecting the space to nature. The maple wood flooring on the interior of cafe and restaurant has a smooth finish and then it transitions to a rough and weathered finish as it merges with the deck of the outdoor dining area. The facades of the wood spaces are primarily double-skin envelopes allowing the building the breath, which will be substantiated on in the following chapter. 


\subsection{Metal: Support Spaces}

The remaining program components are all of the support spaces for the recreation facility. These include offices, administration areas, meeting rooms, classrooms, washrooms, storage spaces, housekeeping, and mechanical and electrical rooms.

The support spaces are correlated to the metal element. The compatible qualitative aspects of the metal element include:

Compass Point: West

Season: Autumn

Action: Splitting

Material: Metal and Steel
Motion: Heavy

Climate: Dry

Organ: Lung

Yin $/$ ang: Increasing Yin

The metal element is associated with west and autumn which are at the end of the successive cycle of the day and the year. The support spaces of the recreation facility relate to this, in that the other program components that take precedence and precede the support spaces. The action of splitting is relevant to the support spaces of the metal element, as they are all split up between other program components. The climate that is related to the metal element is dry. This can be associated with the support programs in that they are distinct from the sweaty, damp, and wet nature of the various recreational activities. The organ associated with the metal element is the lung, which is a life supporting component of the human body. In the same sense the programs associated with the metal element are supporting the components of the recreation facility. The mechanical and electrical spaces allow the building to physically function, the office and administration program is necessary to allow the recreation activities to function, the storage spaces store recreation equipment, and the housekeeping spaces serve to maintain the cleanliness of the facility. The metal element also contains Yin qualities that can be correlated to the support spaces of the program and include: west, structure, quiet, inside, and rough. 
The materiality of the support spaces (metal) is comprised of various metals. The structure of the support spaces are primarily steel, however in areas in which it is integrated with one of the prominent elements such as fire, it accepts the structure of that portion of the building. Cor-ten steel is applied on the exterior facades of the support spaces, which through its weathering properties, acknowledges the presence of nature overtime. Copper and nickel are used on some of the walls of the meeting rooms and classrooms to interact with daylight through reflecting light and perceptually transforming the appearance of the metal wall, in terms of its colour and finish.

\subsection{Building Location and Orientation}

The proposed recreation facility is situated on southern portion of the Bayview Yards site. The location of the facility is determined by pragmatic aspects pertaining to the inherent circulation of the site as well as influenced and informed by the qualitative aspects associated with the Five Elements. The flow and circulation of the site has been explored in terms of vehicular, transit, cyclist, and pedestrian movement to and through the site (Figure 4.1).

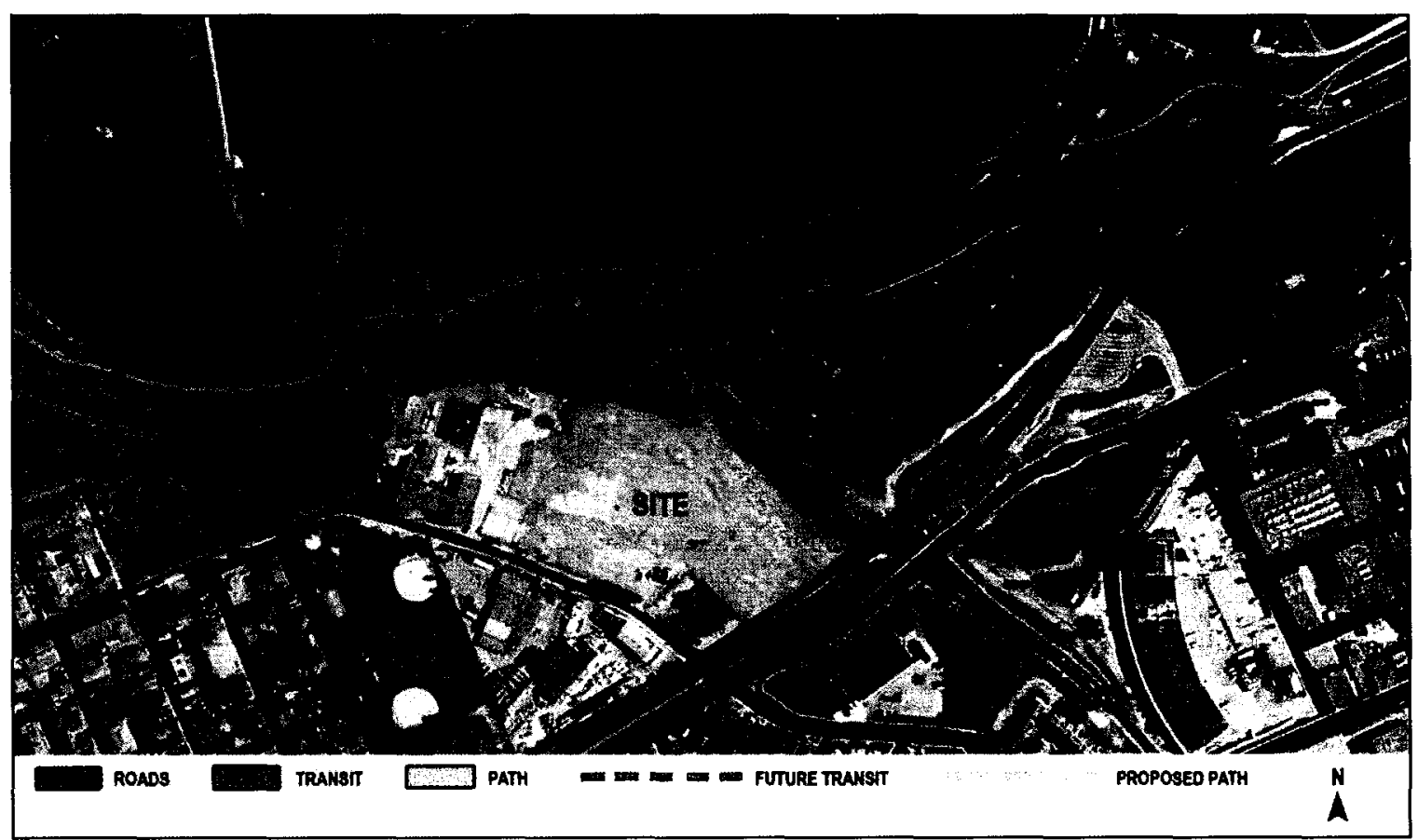

Figure 4.1: Site Circulation Study 
The site has only one street adjoining it which is Bayview Rd. to the west of the site. The transit system is situated to the south-east of the site, and cyclists and pedestrians would access the site either from Bayview Rd. or from the recreation paths along the Ottawa River, north of the site.

Based on the evaluation of the circulation, the proposed recreation facility will be situated on the southern portion of the site, in close proximity to the transit system. With the proposed future transit plans, the assumption is that a vast majority of the potential users of this recreation facility will arrive by transit, which is the primary factor determining the building location on the site. An interior link will be provided from the 0-Train station into the recreation facility to provide transit users with increased accessibility and reduced travel distance to the recreation facility. The vehicular traffic coming from Bayview Rd. is less of a factor in determining the location since parking will be in close proximity to the building. The cyclists and pedestrians have already chosen to walk or cycle so the distance they have to travel is also not a priority.

Additionally to provide easier access for cyclists and pedestrians there will be two proposed outdoor links; one underneath Wellington St. and the transitway creating a path from Tom Brown Arena to the recreation facility, and second path which would run parallel to the unused train track that runs along the eastern portion of the site and goes underneath the Ottawa River Parkway, creating a more direct path from the Ottawa River Recreational Pathway to the recreation facility.

The location and orientation of the program components on the site and within the building is informed by the compass directions (Table 4.2) associated with each of the Five Elements to achieve a

\begin{tabular}{|l|l|}
\hline Element & Compass Direction \\
\hline Wood & East \\
\hline Fire & South \\
\hline Earth & Center \\
\hline Metal & West \\
\hline Water & North \\
\hline
\end{tabular}

Table 4.2 harmonious balance within the building. 
The common spaces which are associated with the wood element are located primarily towards the east of the site. The "dry" activities associated with the fire element are located towards the south of the site. The healing and therapeutic activities associated with the earth element are located in a central location amongst the other program components. The support spaces associated with the metal element are located primarily to the west of the site and other program components. The "wet" activities associated with the water element are located on the north portion of the building. 


\section{Chapter 5: Design \& Cycle of Balance}

\subsection{Introduction}

The Five Elements, with the associated Cycle of Balance, is the guiding principle and method to inform the healthy and balanced design of the recreation facility.

Chapter One introduced the Cycle of Balance and explained how the Five Elements engage in the creation and destruction cycles of change to achieve harmony and balance amongst the Five Elements. The principals of traditional Chinese medicine are concerned with maintaining a balance between the Five Elements as they relate to the human body. A person is considered well balanced and healthy if they have a balance of each of the Five Elements rather than having an element that is over abundant. Based on the concept of balancing the Five Elements to achieve healthiness, this thesis is making an architectural proposition via the program of a recreation facility to achieve a healthy building.

\subsection{Building Massing and Form}

The massing, program adjacencies and building form of the recreation facility are derived from the Cycle of Balance. Table 5.1 shows the Cycle of Balance in correlation to the program component and element relationships developed in Chapter Four. The interactions between the program components and the phases of the cycles are subsequently described. 
Table 5.1: Cycle of Balance Related to Recreation Program

Related program components in italics adjacent to its corresponding element.

Creation/Generating Cycle

Wood (Common Spaces) feeds Fire ( "Dry" Activities)

Fire ("Dry" Activities) creates Earth (Healing and Therapeutic Activities)

Earth (Healing and Therapeutic Activities) bears Metal (Support Spaces)

Metal (Support Spaces) collects Water ("Wet" Activities)

Water ("Wet" Activities) nourishes Wood (Common Spaces)

Destruction/Overcoming Cycle

Wood (Common Spaces) parts Earth (Healing and Therapeutic Activities)

Earth (Healing and Therapeutic Activities) absorbs Water ("Wet" Activities)

Water ("Wet" Activities) quenches Fire ("Dry" Activities)

Fire ("Dry" Activities) melts Metal (Support Spaces)

Metal (Support Spaces) splits Wood (Common Spaces)

The common spaces (wood) feeds the

"dry" activities (fire) both physically in the massing of the two elements and also programmatically as many of the common spaces such as the corridors, change rooms, and locker rooms feed into the "dry" activity spaces such as the gymnasium and fitness center.

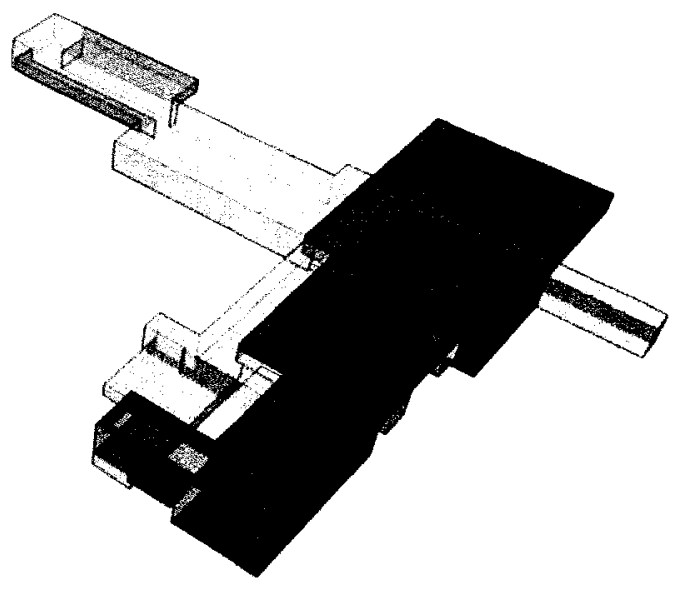

rigure 0.1 - uvooa reeas rire

The "dry" activities (fire) creates the healing and therapeutic activities (earth) physically in the form of the building in the sense that the spa of the healing and therapeutic spaces are raised above the ground on columns and evolves from "dry" activity spaces of the squash courts and fitness centre below.

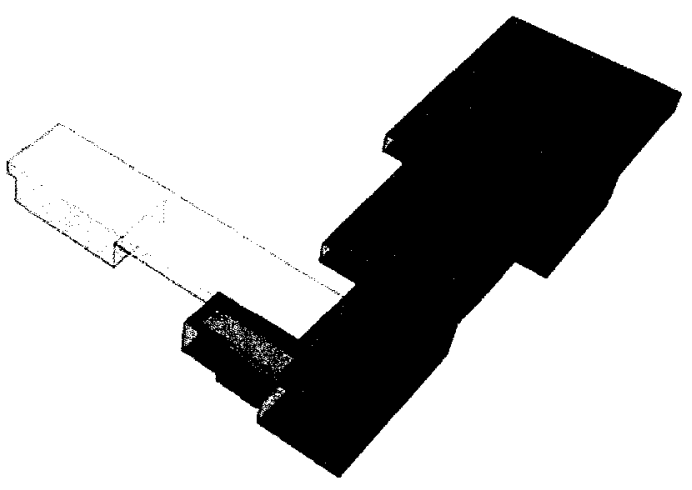

Figure 5.2 - Fire Creates Earth 
The healing and therapeutic activities (earth) bears the support spaces (metal) as the physiotherapy space is raised above and bears down on the support spaces below such as the meeting and education rooms.

The support spaces (metal) collects the "wet" activities (water) physically in the massing as the office and administration spaces are located underneath a portion of the pool program suggesting the notion of metal collecting the water above. Programmatically the support spaces in that area also collect the offices and classrooms that support the swimming programs.

The "wet" activities (water) nourishes the common spaces (wood) physically as the massing of the swimming pools is encompassing the massing of the common spaces such as the lobby, lounge, and locker and change rooms, suggesting the notion of fostering or taking care of them.

The relationships discussed thus far fulfill the requirements for the creation or generating Cycle of Balance. The following sets of interactions are the destruction or overcoming cycles. The combination of

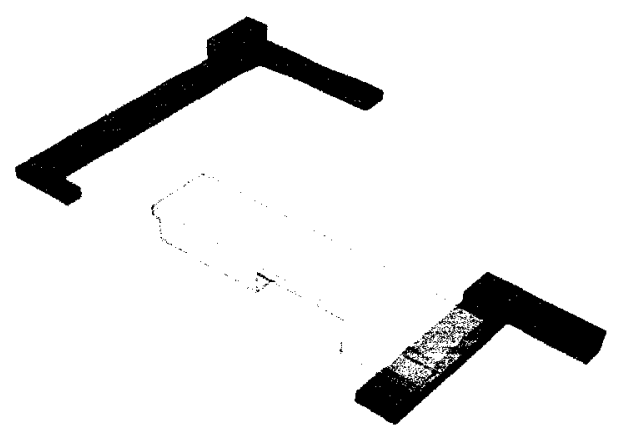

Figure 5.3 - Earth Bears Metal

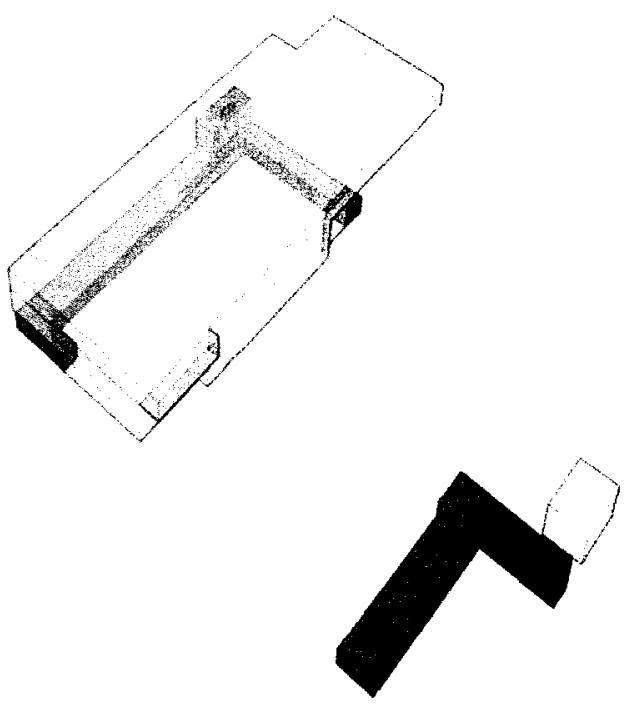

Figure 5.4 - Metal Collects Water

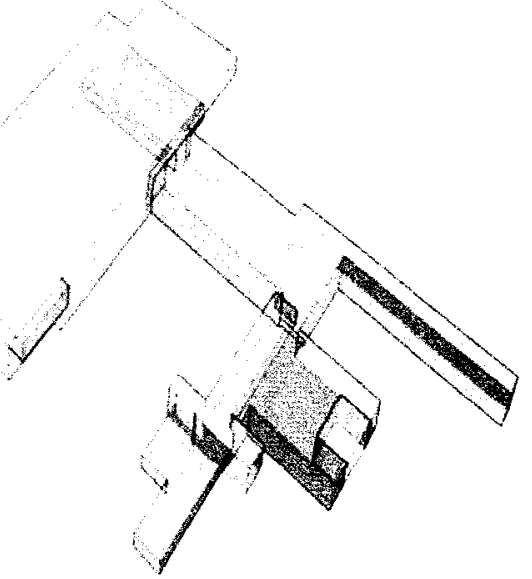

Figure 5.5 -Water Nourishes Wood both the creation and the destruction cycles result in balance. 
The common spaces (wood) parts the healing and therapeutic activities (earth) physically as there is a gap between the roof of the lobby space and the underside of the spa. This parts the two elements and emphasizes the gesture of the spa being raised out of the earth.

The "dry" activities (fire) melts the support spaces (metal) in that the fitness centre and gymnasium of the fire element form the dominant mass above the classrooms and meeting rooms of the metal element below; making them less visible, essentially dissolving and melting them underneath the fire element.

The healing and therapeutic activities (earth) absorbs the "wet" activities (water) which is visible in the massing as some of the healing and therapeutic activities such as the therapeutic pool, hot tub, sauna, and spa overlap and are absorbed within the swimming pool volume. Programmatically the therapeutic pool and hot tub are essentially "wet" activities that have been absorbed into the healing and therapeutic program.

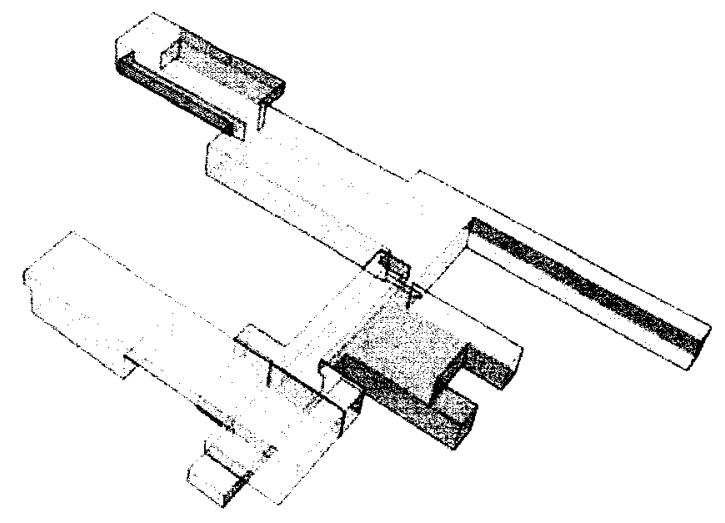

Figure 5.6 - Wood Parts Earth

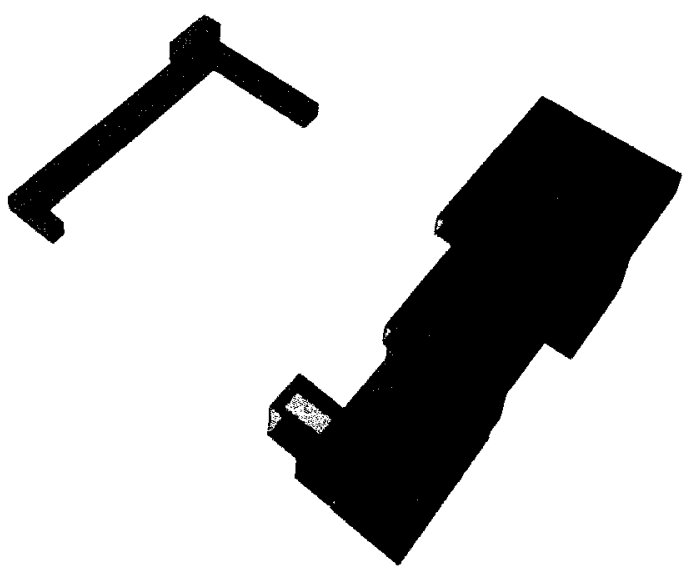

Figure 5.7 - Fire Melts Metal

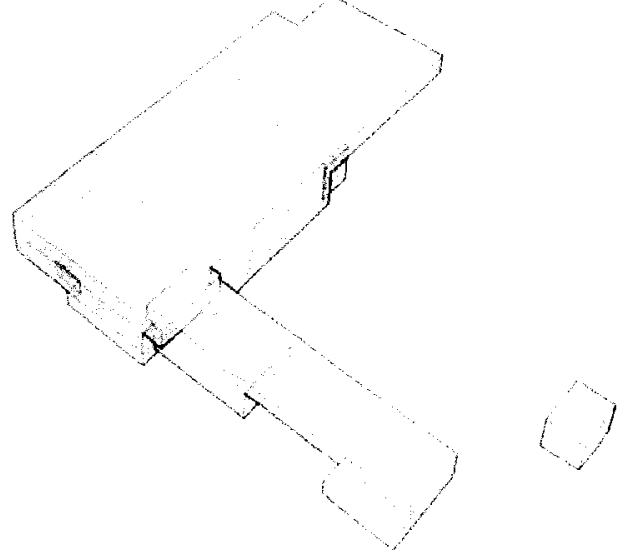

Figure 5.8 - Earth Absorbs Water 
The "wet" activities (water) quenches the "dry" activities (fire) programmatically as the showers cool the users of the heated "dry" activities such as the gymnasium, squash courts, fitness centre, tennis courts, and indoor track. Formally the "wet" activity space of the shower quenches the "dry" activities in the sense that it subdues a primarily "dry" activity volume.

The support spaces (metal) splits the common spaces (wood) physically in the massing of the building as some of the support spaces such as the meeting rooms, education rooms, storage and mechanical spaces intersect and split through the common spaces such as the lobby and corridor.

The amount of space and program allotted to each of the elements varies, with water and fire being the most prominent. However, the remaining elements are well balanced and overall there is a harmonious stability.

The various massing relationships that have been formed by the interpretation of the Cycle of Balance in conjunction with the program components

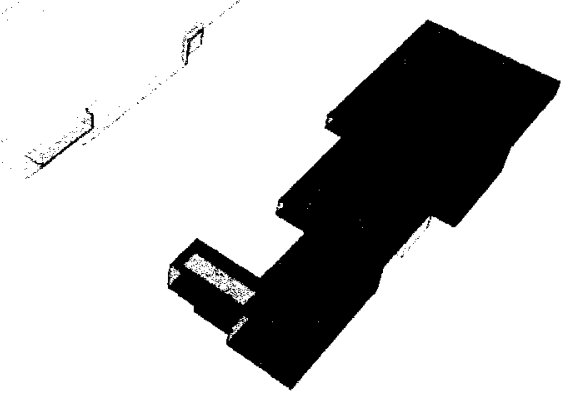

Figure 5.9 - Water Quenches Fire

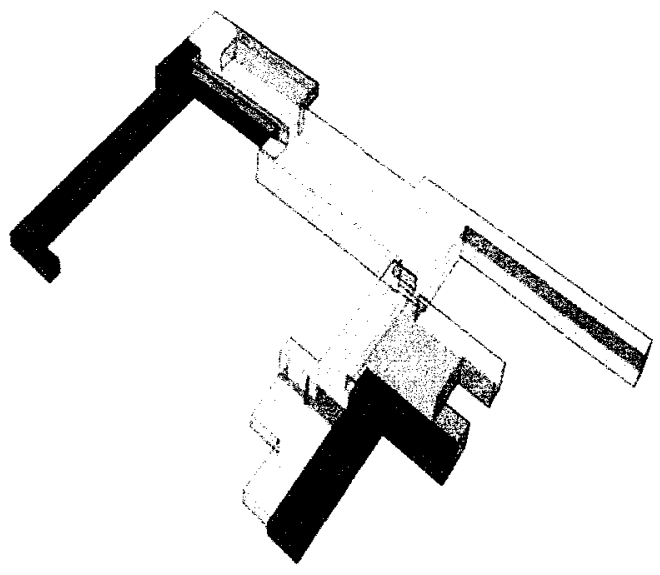

Figure 5.10 - Metal Splits Wood

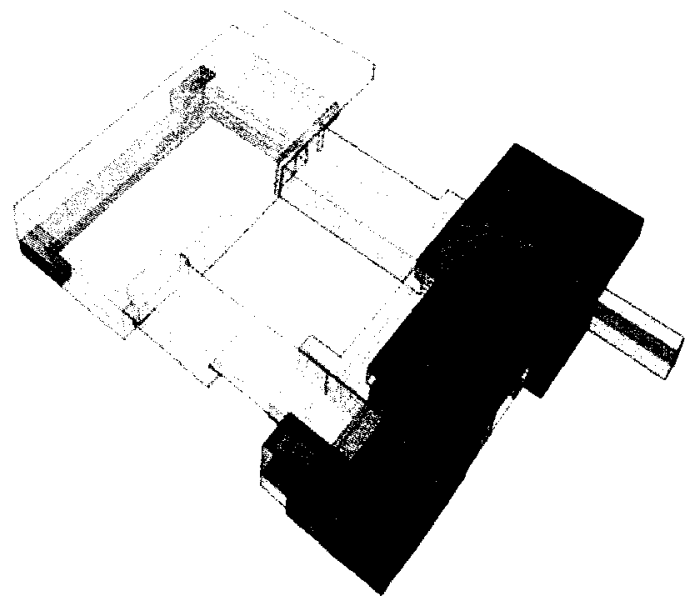

Figure 5.11 - All Elements Balanced creates in a void in the massing of the building. This void forms the courtyard space and is the outcome of a balanced building, representing the ideal state of harmony. To acknowledge this inherent meaning, the courtyard is a synthesis of the Five Elements. 
Each of the Five Elements is distinctly manifested in the courtyard. The "wood" element represented by the tall pine trees subtly following and continuing the structural pattern of the tall wood columns in the corridors and cafe space (wood). Pine trees were selected for their height and coincide with the notion of "tall", which is a qualitative aspect of the wood element. Wind is also associated with the wood element. The pine trees in the courtyard poetically express the breeze from the wind, heightening the awareness that the wind is capable of moving through the void of the courtyard and into the building, allowing the building to breath through natural and cross ventilation which is discussed later in this chapter.

The "fire" element is physically evident in the courtyard through a fire pit that serves the exterior dining and cooking spaces of the recreation facility's restaurant and café. Heat, light and intensity are qualitative aspects of the fire element that are present in the courtyard fire pit. During the night the burning fire provides a source of light and heat for the courtyard space. Weather conditions such as wind, rain, and snow will alter the intensity of the constantly burning fire and increase awareness of the naturally changing climatic conditions, heightening a sense of place.

The courtyard itself expressive of the "earth" element as it is sunken and grounded into the earth; contrasting, yet balancing with the "earth" element of the recreation facility which is a horizontal volume raised in the sky and coming out of the earth. Within the Five Elements, earth is in a central position just as the courtyard is, therefore making the courtyard a fundamental component for the balance of the recreation facility. Earth is a very natural substance, the materials in the courtyard consist of grass, water, wood, and other natural materials associated with the earth element such as stone, rocks, and rammed earth, which form the materiality of the walls and paving in the courtyard.

The "metal" element is present in the courtyard through the stainless steel air in-take tubes that extend from the courtyard, through a reflecting pond, and into the ground. The organ 
associated with "metal" is the lung which is concerned with breathing and air, so through the metal air in-take tubes the building is able to breath. This is explained in further detail in section 5.13.

The "water" element is physically present in the courtyard in the form of a reflecting pond that perceptually suggests a continuation of water from the adjacent indoor swimming pools. The courtyard is sloped so that the rainwater will drain into the reflecting pond, solving the concern for drainage. The water element is associated with the kidney, an organ that filters, and balances bodily fluids, which is similar to the courtyard's water element, the reflecting pond. Through the drainage process, the reflecting pond filters and balances the water level in the courtyard, which will vary in water level depending on the weather and time of year.

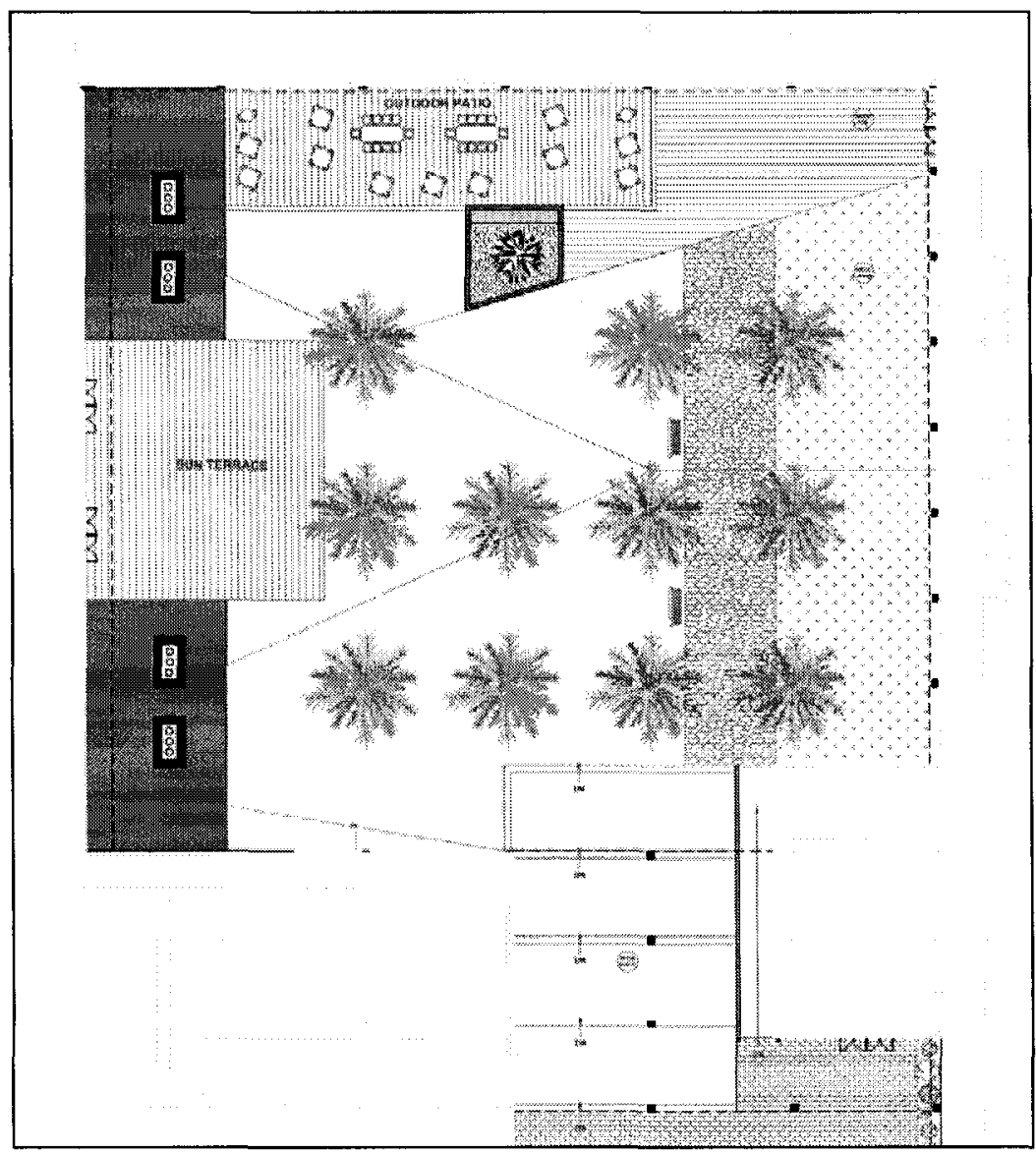

Figure 5.12 - Courtyard Plan 


\subsection{Sustainable and Healthy Design Approaches}

The quest for environmental value in architecture, for a harmonious balance between man and his surroundings, is not new. For centuries, and particularly in domestic and vernacular architecture, people adopted this approach out of necessity. Since the industrial revolution, it has been increasingly abandoned in favour of man's belief in his own omnipotence and ability to draw unrestrainedly on the earth's resources. ${ }^{91}$

Prior to the multitude of technical solutions derived to achieve human comfort within our built environment, traditional architecture achieved comfortable environments through the fundamental principles of design. Thermal building mass principles were incorporated in cold European climates to maintain comfortable environments by incorporating Roman hypocaust heating systems in conjunction with radiant heating and thermal mass. ${ }^{92}$ The Turkish aristocracy implemented similar building strategies using building mass and radiant heat transfer to maintain the comfort of their palaces through channeling a stream of cool water through the palace walls during the hot summer months to naturally provide a cool interior environment. ${ }^{93}$

Many of the techniques and building systems that have been developed and constructed over two millennia ago, including those discussed in the previous paragraph, provide natural approaches for controlling indoor temperature, light, recovering rainwater, and ventilation through methods that are still applicable today without resorting to high-cost, high-energy technical solutions. The sustainable, healthy approaches that have traditionally been implemented will be explored in conjunction with each successive phase inherent in the Cycle of Balance, derived from the Five Elements Theory and used in traditional Chinese medicine to balance the health of the body, and similarly create a healthy, balanced design for the proposed recreation facility. The design and details of these will be discussed and demonstrated in the following sections.

\footnotetext{
91 Dominique Gauzin-Muller. Sustainable Architecture and Urbanism: Concepts, Technologies, Examples. (Basel: Birkhauser, 2002), 12.

${ }^{92}$ Geoff McDonell. "Radiant Solutions," Canadian Architect 48 (3) (2003): 38.

93 lbid., 38.
} 


\subsection{Wood Feeds Fire - Natural Ventilation}

The wood feeds fire relationship provides a breath of fresh air for the recreation facility. Wind is the climatic condition associated with the wood element and air which is associated with wind is the primary constituent of the wood feeds fire relationship. The notion of air feeding fire can be understood literally as air being a necessary ingredient for fire to burn. This is analogous to the relationship between the corridors of the recreation facility (wood) and the gymnasium and indoor track (fire). The breeze of air flowing into the corridors and feeding into the gymnasium is a necessary ingredient for providing a healthy environment.

The corridors on the eastern and western facade of the proposed recreation facility, surrounding the gymnasium and indoor track are double-skin envelopes essentially playing the role of the lungs of the body (building); breathing in fresh air (natural ventilation) ${ }^{94}$. The prevailing winds on this site come from the west so they will have an impact on the west facing lungs of the building and through the void forming the courtyard the building is able to 'breathe' by allowing for the cross ventilation of the prevailing winds through the double-skin envelope. The breeze of air flows through the lungs of the building, through the operable windows and the dampers at the bottom of the cavity of the continuous double-skin building envelope and then into the building (body) through the operable windows on the interior side of the double-skin. Portions of the gymnasium walls are glazed with operable windows, allowing the fresh air that has been breathed in through the lungs of the building, to enter into the gymnasium. Similar to the lungs of a body exchanging air (breathing in oxygen and releasing carbon dioxide), the recreation facility also exchanges air. Following basic principles of natural ventilation and stack effect, the warm air from the gymnasium will rise into the space of the indoor track above where the warm air will exit the

\footnotetext{
94 Natural ventilation is triggered by wind pressure and thermal buoyancy (stack effect). Nick Baker and Koen Steemers. Energy and Environment in Architecture: A Technical Design Guide. (New York: Routledge, 2000), 55.
} 
building through the ventilated light wells on the roof of the building, in turn generating a demand for new cool, fresh air to enter the gymnasium and regulate the overall temperature. (Figure 5.13) This is a crucial strategy for the gymnasium and indoor track as they are environments which contain excess heat and humidity from the heated activities which take place in those spaces, making it important for fresh air to be introduced and circulated into the space while allowing for the warm air to dissipate back into the natural environment.

The development of the common technology found today in our built environment, such as electric motors, fans, and ductwork has reduced the ability for a building to naturally breathe fresh air. "Occupants are much happier and healthier in naturally ventilated buildings, in spite of the variability of environmental conditions which results. Sick-building syndrome is almost exclusively observed in mechanically ventilated buildings". ${ }^{95}$ There is a growing concern about air quality in our buildings; allowing the building to breathe through a natural respiratory system (natural ventilation) is a healthy way for the recreation center to get a breath a fresh air.

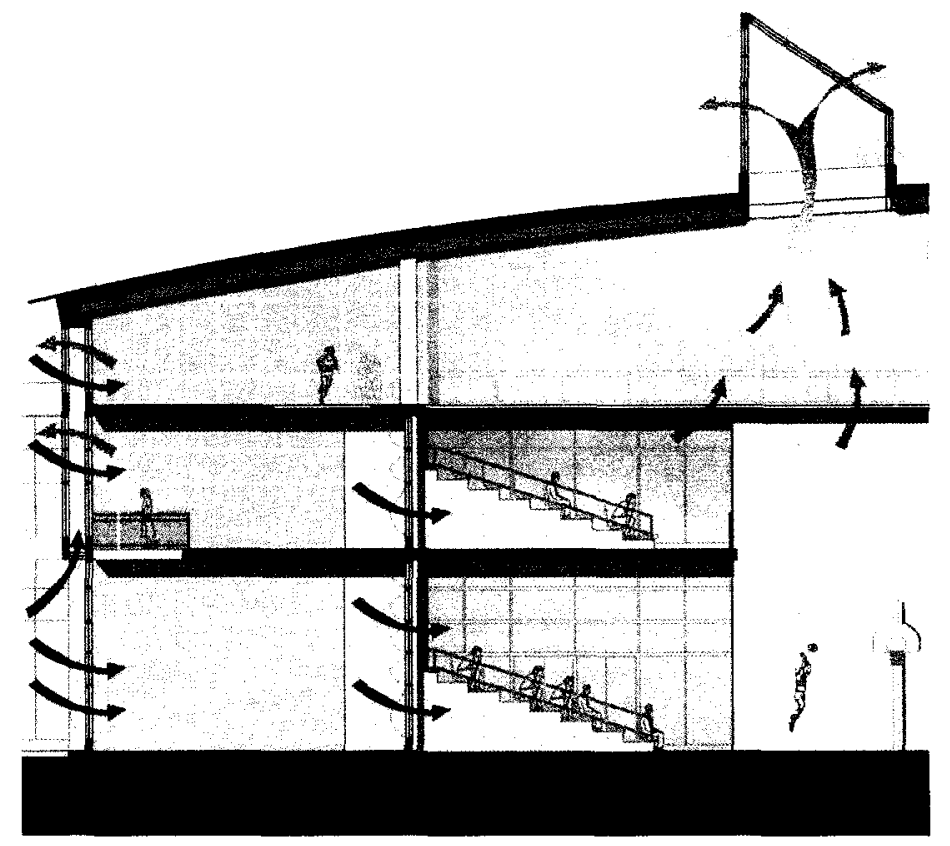

Figure 5.13 - Wood Feeds Fire - Natural Ventilation

${ }_{95}$ Nick Baker and Koen Steemers. Energy and Environment in Architecture: A Technical Design Guide. (New York: Routledge, 2000), 52. 


\subsection{Fire Creates Earth - Thermal Mass and Rammed Earth}

The fire creates earth relationship occurs in the three-storey atrium that intersects through the fitness center (fire), and the spa and physiotherapy (earth) components and also in the southfacing walls of the suspended spa (earth). (Figure 5.14) The idea of creating can be interpreted as a method of generating something. Light and heat, properties of the fire element are used to generate or create a stable temperature balance within the earth element through the thermal mass inherent in the rammed earth wall construction of the spa and physiotherapy walls adjacent the atrium and in the suspended portion of the spa. This notion of stableness is also a qualitative aspect of the earth element. (Table 1.1) The rammed earth walls consist of warm tones of horizontal bands of earth, achieved through the addition of concrete colourants to the soil mixture to capture the rays of sunlight and create a sedimentary appearance, poetically expressing the earth element.

The touch of the earth walls consisting of clay, silt, sand, and sometimes larger aggregates such as gravel or stones sensuously vary from warm to cool. The walls exposed to the interior of the light-filled atrium and the exterior of the spa are warm as they capture the fire from the sunlight and absorb the heat in the thickness of the wall. ${ }^{96}$ The interior walls are cool to touch; the heat absorbed in the rammed earth wall is gradually released into the interior environment as the outside temperature drops allowing the wall to naturally maintain a higher internal temperature, requiring less energy to heat the space as the temperature is naturally controlled and stabilized through the thickness of earth.97

\footnotetext{
${ }^{96}$ Both conditions benefit from optimizing passive solar gain to maintain and balance the indoor climate due to their south and west orientation.

${ }^{97}$ Nick Baker and Koen Steemers. Energy and Environment in Architecture: A Technical Design Guide. (New York: Routledge, 2000), 39.
} 
In addition to absorbing the fire from the sun and analogous to the role of the spleen associated with the earth element which filters blood in the body to maintain health, the porous nature of the natural materials in the rammed earth wall construction, naturally filter the air from the varying conditions on either side of the wall through quickly absorbing or desorbing the humidity, balancing the internal climate. This will create a healthy living environment within the recreation centre as the humidity is decreased in the summer and increased in the winter..$^{98}$ "Air humidity in contained spaces has a significant impact on the health of inhabitants, and earth has the ability to balance indoor humidity like no other building material." $" 99$

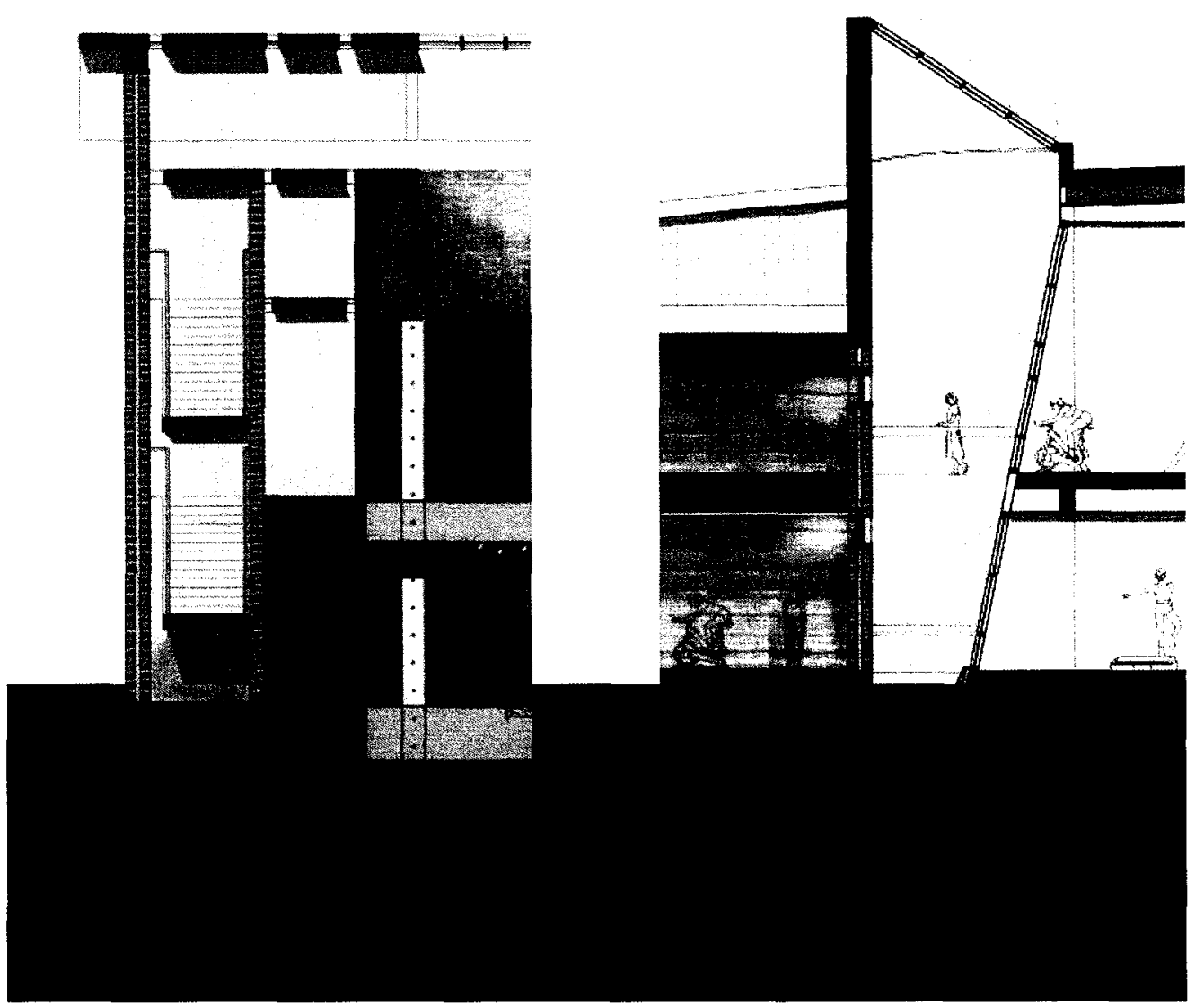

Figure 5.14 - Fire Creates Earth - Rammed Earth Walls

98 Ibid., 14.

ss Ibid., 15. 
The construction of rammed earth walls is not new. Rammed earth construction has been implemented for thousands of years but only recently has it been increasing in interest as a healthy, environment-friendly building material. ${ }^{100}$ Earth is a natural building material that is available in most regions of the world. Rammed earth walls have been common not only in hot climates, but also in the colder climates of many European countries, China, Australia, and it is beginning to be implemented in the Western United States and Canada. ${ }^{101}$ The construction method for creating a rammed-earth wall is not much different than constructing a typical concrete wall. Often the earth mixture can be extracted directly from the site, from the excavated soil. However, for the proposed recreation facility the excavated soil is contaminated so soil from another site will need to be used.

The Nk'Mip Desert Cultural Centre designed by architects, Hotson, Bakker, Boniface, Haden (HBBH) is located on the Osoyoos Indian Reserve in British Columbia is a recent example of a project engaging rammed earth wall construction. It is the first project to incorporate a rammed earth wall of such a large scale, measuring 80 meters in length and 5.5 meters in height. ${ }^{102}$ The rammed earth wall in the Nk'Mip Desert Cultural Centre has the same appearance on both the interior and exterior of the wall and is poetically expressed as a wall constructed out local soil, inheriting the rich colours and textures of the desert embedding an aesthetic quality, but also evoking values of sustainability. ${ }^{103}$ (Figure 5.15 )

The rammed earth walls of the Nk'Mip Desert Cultural Centre are oriented to benefit from passive solar gain and mediate between the extreme temperature differences in the desert, which range from -18 Celsius in the winter to +33 in the summer. The temperature extremes are similar

\footnotetext{
100 Minke Gemot. Building with Earth: Design and Technology of a Sustainable Architecture. (Boston: Birkhauser Publishers for Architecture, 2006), 1

101 Bruce Haden and Brady Dunlop. "Terra Firma," Canadian Architect 52 (3) (2007): 32.

102 Peeroj Thakre. "Earth and Sky," Canadian Architect 52 (3) (2007): 29.

103 lbid., 29.
} 
to the temperature conditions for the site of the proposed recreation facility in Ottawa. The thermal mass of the rammed earth wall controls and balances the interior temperature of the Nk'Mip Desert Cultural Centre, allowing the building to rely less frequently on mechanical means of heating and cooling, and in addition, the materials of a rammed earth wall construction are environmentally friendly, demonstrating the extreme potential from a sustainability and "healthy" building perspective to implement rammed earth wall construction. Hopefully with the growing interest in the green building movement more rammed earth wall constructions will be realized

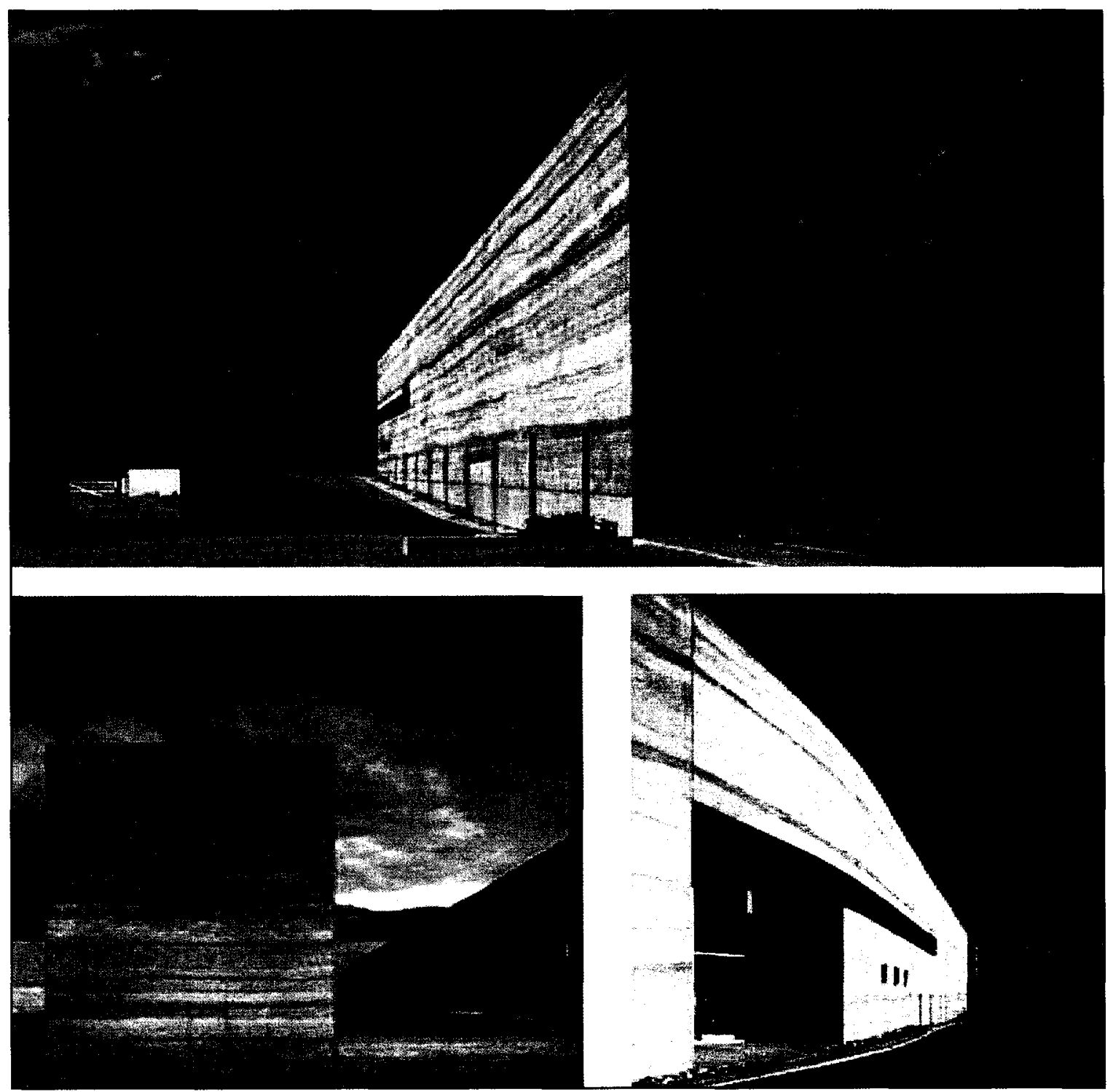

Figure 5.15 -Nk'Mip Desert Cultural Centre

Images of the rich desert colours and textures inherent in the rammed earth wall. 


\subsection{Earth Bears Metal - Site Remediation}

The earth bears metal relationship occurs at the larger scale of the site as a whole. The site or more specifically, the ground is considered the earth element and the contaminants in the earth comprise the metal element. Currently earth bears metal in the sense that it is containing physical remnants of metal. However the notion of bearing can also be interpreted as the idea of transferring, or exerting pressure or force on something. Earth bears metal through exerting pressure on the metal remnants buried in the layers of earth, and transforming ${ }^{104}$ and harvesting ${ }^{105}$ them into a healthy substance through a process of phytoremediation ${ }^{106}$.

The Bayview Yards site may appear to be just another vacant, leftover space within the city waiting for a decision on development proposals. However, not far below the surface layer of the grass, weeds, shrubs, and trees that spread across the vast site there are layers of metal remnants from the site's previous industrial uses. The Bayview Yards site has undergone several environmental testing procedures and has been deemed a contaminated site. This brownfield site has enormous potential to become a vital site within the city; due to its proximity to several Ottawa neighbourhoods, transit systems, and recreation systems. However the contamination of the site has prevented any immediate development, and is the cause of the site's vacancy over the last few decades.

Remediating the site is an obvious solution. There is irony present in the fact there is a proposed "healthy building" to be situated on this contaminated site. A "healthy building" requires a "healthy site" to work in unison to create a "healthy environment". Creating a "healthy site" requires

\footnotetext{
104 Transformation is a qualitative aspect of the earth element. (see Table 1.1)

${ }^{105}$ Harvest is a qualitative aspect of the metal element. (see Table 1.1)

${ }^{106}$ Phytoremediation is a biological remediation process that uses plant systems to decontaminate polluted air, water, and soil.

Todd Zynda, EnviroTools: Michigan State University and National Institute of Environmental Health Sciences.

Phytoremediation, 2001, <http://www.envirotools.org/factsheets/phytoremediation.html> (accessed January 23, 2008).
} 
adding a healthy ingredient to balance the unhealthy ingredients of the metal remnants buried in the earth's layers through a process of phytoremediation as opposed to removing or relocating the contaminants.

Remediating this brownfield site will become a lengthy process. The proposed Master Plan for this site includes phased development. (Figure 5.16) The initial phase of this project will include the construction of the proposed recreation facility on the south portion of the Bayview Yards site. The soil that is excavated for the construction of the recreation facility will be placed in mounds on the remainder of the site, establishing a dynamic landscape that can form interesting views from the recreation facility and will direct the wind and water so that it can nourish the building. Using the excavated soil from the recreation facility in the remediation process as opposed to transporting the problem of the contaminated soil to another site or landfill, is a perceptible reminder of the healing process that the earth bears on metal.

The earth element is associated with the spleen organ, a part of the human immune system which filters blood and fights infection. Similarly the relationship of earth bearing metal is concerned with the earth filtering the metal which it bears to fight the resulting infectious site conditions. The healing process that earth bears on metal is in the form of Phytoremediation ${ }^{107}$. This form of remediation and healing land is not new, historically in ecosystems, contaminants buried in the earth have naturally been known to cycle through plants. ${ }^{108}$ The added ingredients for this healing process include planting willow and poplar trees, grasses with fribous roots such as

\footnotetext{
${ }^{107}$ Phytoremediation is a biological remediation process that uses plant systems to decontaminate polluted air, water, and soil.

Todd Zynda, EnviroTools: Michigan State University and National Institute of Environmental Health Sciences.

Phytoremediation, 2001, <http://www.envirotools.org/factsheets/phytoremediation.htmi> (accessed January 23, 2008).

$108 \mathrm{lbid}$.
} 
rye and bermuda to partake in a process of phytovolatization ${ }^{109}$. Other plants such as dandelions, Indian mustard, nettles, and sunflowers will also be planted and partake in the phytoaccumulation ${ }^{110}$ process. Through this return to nature, the infectious metal remnants that the earth bears will be decontaminated, reviving the earth to its natural healthy state. Using plants to decontaminate the site is cost effective compared to other treatment methods and simultaneously creates an aesthetically pleasing landscape, which over a period of many years, evolves and remediates.

Although this healing process is a cost effective method to treat the earth; it takes time. It will be several years after the site has been planted before it can be used again. In the meantime, the variation of plants will change and grow with the passing seasons, gently move with the breezes, reflect the warmth of the sun, and create an aesthetically pleasing landscape, which over a period of many years, the earth bearing metal will evolve and remediate. Once the site is determined to no longer be contaminated then the successive phases of the master plan can evolve through its next stages.

Once the recreation facility is constructed, it is proposed that the successive phases will transform the remainder of the site into a combination of sports fields for soccer and football, recreational paths for pedestrians and cyclists, an outdoor rink used for ice skating in the winter and roller hockey in the summer, and open flexible spaces, varying in size and unassigned with any specific program to provide opportunities for a wide range of events. The evolution of this site

\footnotetext{
109 Phytovolatization: a method of phytoremediation in which the "plants take up water and organic contaminants through the roots, transport them to the leaves, and release the contaminants as a reduced or detoxified vapor into the atmosphere."

Todd Zynda, EnviroTools: Michigan State University and National Institute of Environmental Health Sciences. Phytoremediation, 2001, <http://www.envirotools.org/factsheets/phytoremediation.html> (accessed January 23, 2008). 110 Phytoaccumulation: a method of phytoremediation in which "plant roots can remove metals from contaminated sites and transport them to leaves and stems for harvesting and disposal or metal recovery through smelting processes." Todd Zynda, EnviroTools: Michigan State University and National Institute of Environmental Health Sciences. Phytoremediation, 2001, <http://www.envirotools.org/factsheets/phytoremediation.html> (accessed January 23, 2008).
} 
through the proposed phases acknowledges the earth bears meta/ relationship by making visible the transformation of the remediation process to the inhabitants and will transform a once abandoned, contaminated site into a healthy and diverse urban recreational environment.

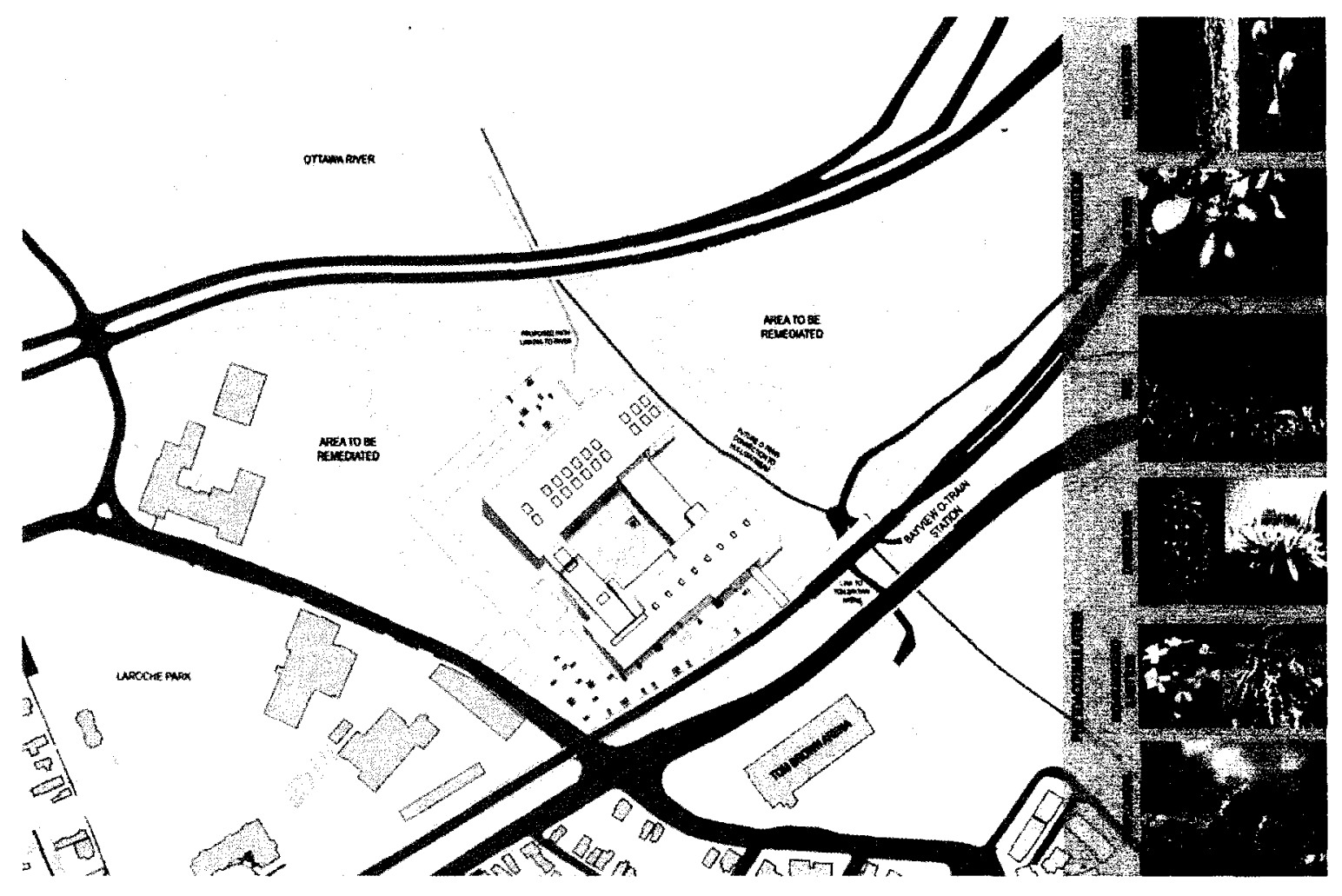

Figure 5.16 - Master Plan of Site 


\subsection{Metal Collects Water - Rainwater Recovery}

The metal collects water relationship occurs where the water component of the building intersects with the earth component. Water is a resource that is continuously wasted and taken for granted. Historically, many parts of the world have been concerned with collecting and harvesting rainwater. In addition to collecting the water for the purpose of reusing it for everyday uses such as flushing toilets and cleaning, the qualitative aspects of water can be simultaneously exposed, especially in the healing and therapeutic environment of the earth element.

Typically the rainwater which pours onto the roofs of buildings quickly flows off the roof through metal eaves attached to the buildings facade before disappearing unutilized into the earth, missing the opportunity to poetically collect the water, heightening awareness of precious resource and experiencing the sensuous qualities of water. The rainwater that flows off of the roof of the swimming pool pours through a cavity in the wall and is collected below the surface of the building in an underground water cistern. This subterranean collection of water is associated with the metal element as metal elements are supportive spaces for the recreation facility and the water which is accumulated is used to support many of the water uses within the building. ${ }^{111}$

The journey of the rainwater from the roof of the building to the underground cistern where it is collected and accumulates is the missed opportunity of the typical method of disposing rainwater from the roof. Inside the wall cavity, a sloped stone ledge penetrates into the void just far enough to capture a few drops of rainwater entering the wall cavity and directs the rainwater onto a sheet of cor-ten steel that is clad onto the exterior wall of the cavity and penetrates through each level into the spaces containing the spa, hot tub, and therapeutic pool. (Figure 5.17) The

\footnotetext{
111 The water collected in the cistern undergoes a maintenance free two-stage purification process within the cistern prior to being distributed with low-energy pumps throughout the building. Through advanced filtering and purification processes, the recovered water could also be stored and used for the swimming pools.

Dominique Gauzin-Muller. Sustainable Architecture and Urbanism: Concepts, Technologies, Examples. (Basel:

Birkhauser, 2002), 105.
} 
weathering properties of the cor-ten steel in conjunction with the rainwater dripping down it, will allow the steel to gradually change its appearance, naturally demonstrating what occurs when metal collects water.

The sides of the wall cavity are glazed, providing a view into the cavity collecting water, reflecting the changing rain conditions both visually and by the varying sound of water pouring into the cavity. The sensuous contrast between the temperature of the lukewarm therapeutic pool water and the hot water in the hot tubs in conjunction with the touch of the cold steel and varying temperature of the rainwater dripping down it also heightens the awareness of the natural environmental conditions.

As the site is currently heavily contaminated, the recovery of rainwater is limited to the collection of water on the roof of the building rather than surface water. Once the remediation process is complete the recovery of surface water can be integrated into the design. Incorporating

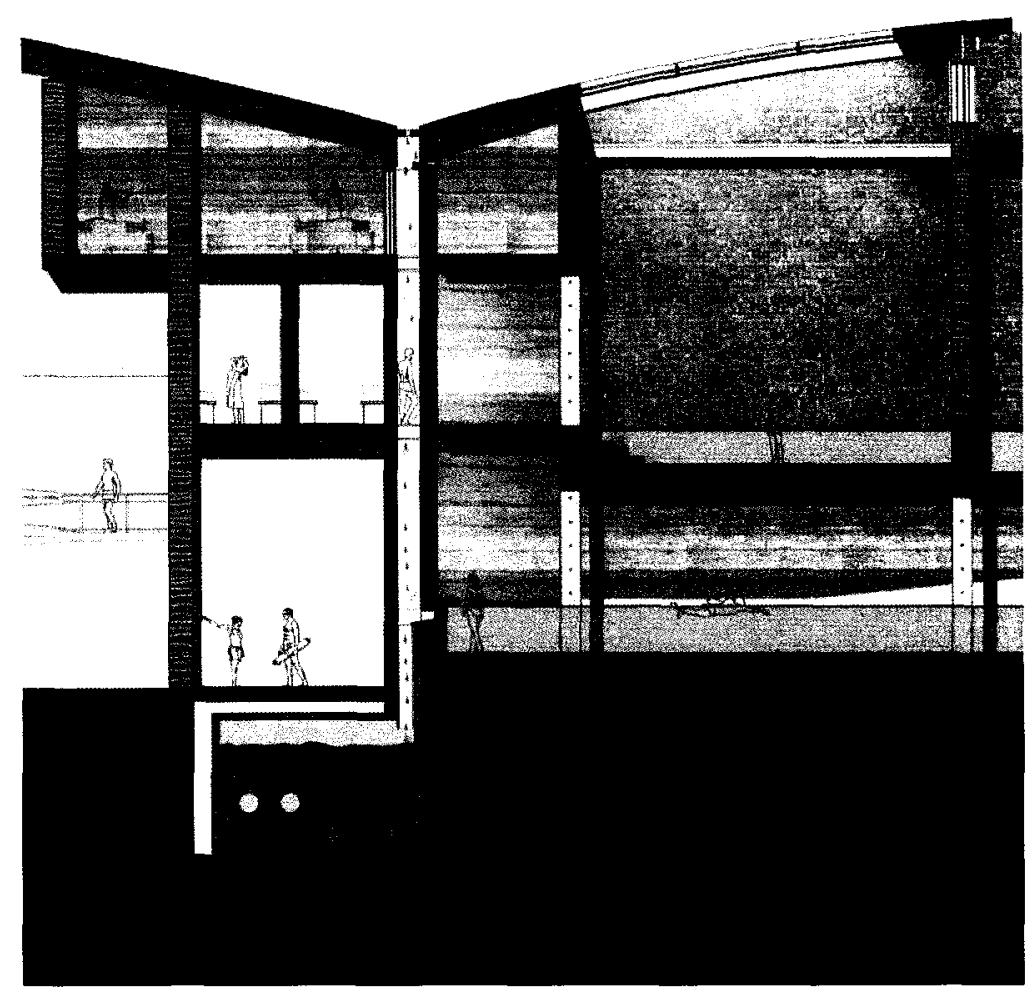

Figure 5.17 - Metal Collects Water - Rainwater Recovery System a rainwater recovery system, which heightens the awareness of water consumption in the recreation facility, as well as exposes the qualitative aspects of water, is a small move to creating a sustainable environment. 


\subsection{Water Nourishes Wood - Biowall}

The water nourishes wood relationship is established along the wall separating the swimming pools (water) from the adjacent cafe (wood). The idea of nourishing is about sustaining with the necessities of life, health, and growth. Providing healthy air is a necessity for health and is achieved through the water nourishes wood relationship in the form of a vertical wall of plants between the water and wood element of the recreation facility.

The Integrated Learning Centre at Queen's University in Kingston, Ontario, designed by $\mathrm{B}+\mathrm{H}$ Architects also incorporates a large wall of plants in the form of a biowall 112 in the main lobby of the building. (Figure 5.18) The large threestorey wall of plants becomes a dominant feature in the public space of the building and similar to the strategies implemented in the design of the proposed recreation facility, the Integrated Learning Centre (IL Centre) is employing several sustainable building solutions to allow the students studying applied sciences to learn from the building.

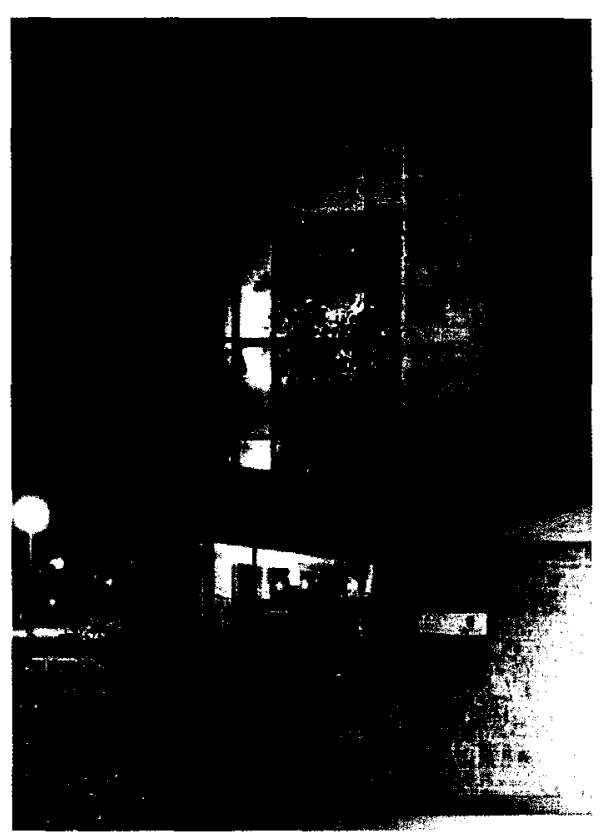

Figure 5.18 - Biowall IL Centre - Queens University

The vertical wall of plants (biowall) in the IL Centre is a natural air filter that purifies the air through the plants, then circulating purified, clean air throughout the building. The plants are embedded and woven into two layers of porous material which is appended to a concrete wall, with the roots of the plants growing downwards between the layers. ${ }^{113} \mathrm{~A}$ variety of plants are able to

$112 \mathrm{~A}$ biowall improves the overall internal air quality through filtering VOCs, $\mathrm{CO}$, and many other common pollutants from the air. Leslie Jen. "Green Machine [Integrated Learning Centre at Beamish-Munro Hall]," Canadian Architect 50 (1) (2007): 16.

${ }_{113}$ Queens University and the contributors, Biowall, 2006, <http://ivebuilding.queensu.ca/green_features/biowall> (accessed November 23, 2007). 
sustain themselves on the wall, however to maintain a healthy balanced wall, if some of the plants are struggling to survive then they will be exchanged for a different plant.

For the plants to nourish the building with purified air it needs water to nourish the plants. Water is pumped to the top of the wall and then flows down the back of the wall through the various plant layers, keeping the roots of the plants moist. ${ }^{114}$ On each of the three floors of the IL Centre, a fan is located within the biowall and triggered by the internal humidity levels, drawing the air through the plants and into the building. ${ }^{115}$ Figure 5.19 is a detail section demonstrating how this works. Maintenance is minimal and consists of no more than dusting the plants and draining and changing the water once a month.

The ten-meter high vertical wall of plants proposed for the recreation facility is similar to the one implemented at the $\mathrm{IL}$ Centre at Queen's University. The wall of plants satisfies the relationship of water nourishing wood since the water that is moved through the wall is a necessity for nourishing the plants (wood) so they can in turn nourish the spaces of the wood element with purified, clean air. The plants on the wall are similar to those used on the biowall of the IL Centre which consist of mainly leafy ferns, with orchids working

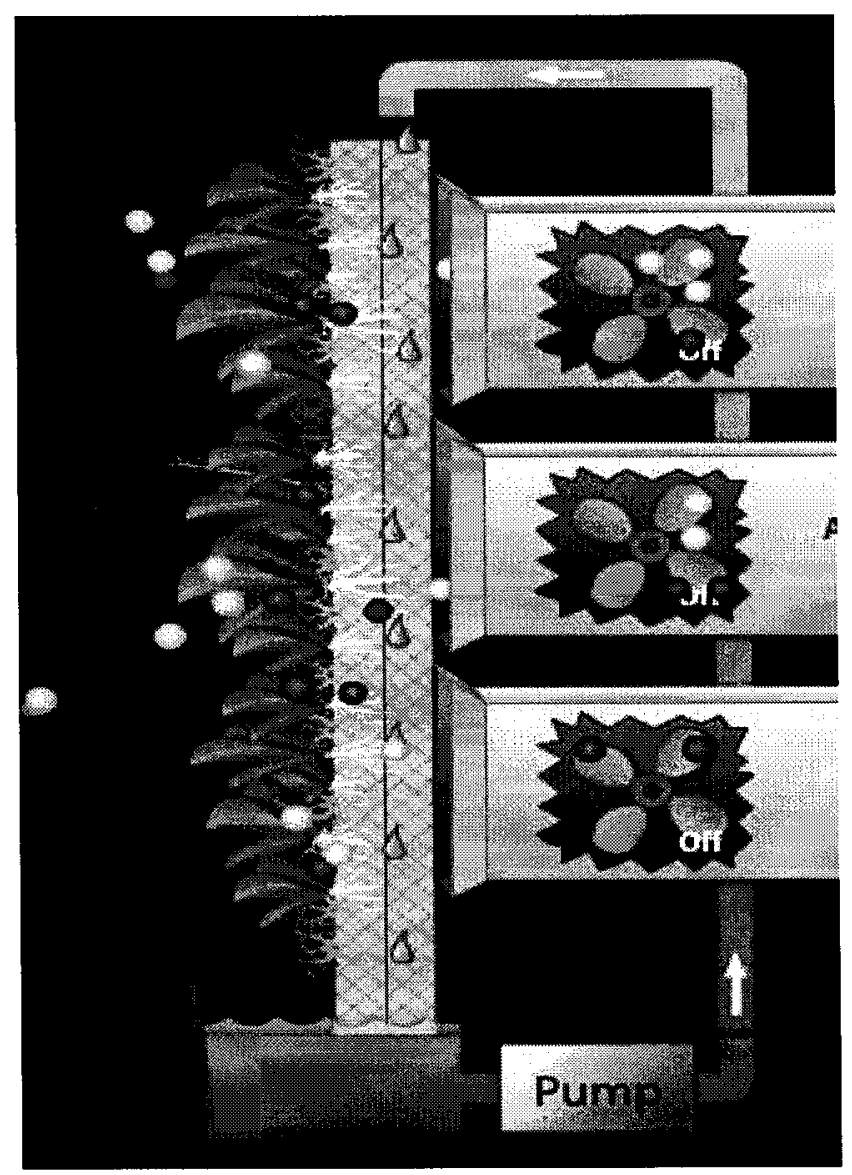

Figure 5.19 - Biowall Diagram

114 Ibid.

115 Ibid. 
quite well. ${ }^{116}$ Differing from the IL Centre, the water that is used to nourish the plants flows from the swimming pools, with the salt from the pool water being extracted; then pumping the purified and filtered water through the mass of plants before being recycled as clean water into the swimming pools. (Figure 5.20) The fans that are part of the biowall system in the IL Centre will also be implemented in this biowall design, however in addition a light shaft will be located within the biowall. The purpose of the light shaft is to naturally raise the filtered air, then allowing the air to enter the ventilation system and be redistributed into the recreation facility. The fans which are triggered by humidity will only be implemented when required. The proposed vertical wall of plants is an important sustainable design strategy within the recreation facility as it will supply the building and its inhabitants with healthy air, creating a healthy environment.

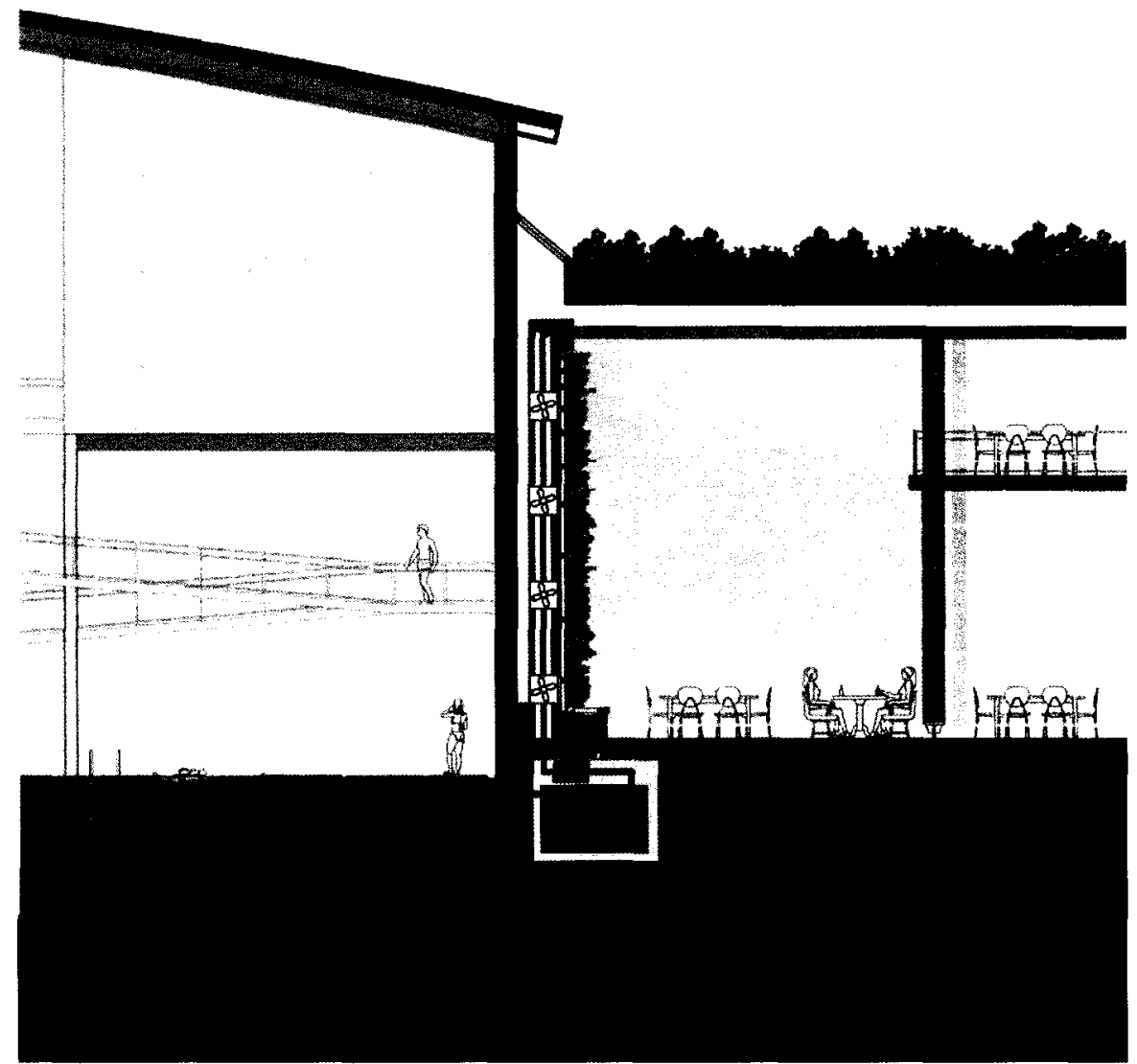

Figure 5.20 - Water Nourishes Wood - Biowall

116 lbid. 


\subsection{Wood Parts Earth - Natural Ventilation}

The wood parts earth relationship follows similar strategies as the wood feeds fire relationship, however with a different method and location. Air, which relates to the wood element, is once again a primary constituent. There is a void between the main lobby of the recreation facility (wood) and the roof of the lobby and the suspended spa (earth) above. This separation demonstrates the idea of the wood parting from the earth. The void, intentionally and carefully located allows the spaces interacting with it to breath. Similar to the walls discussed in the wood feeds fire relationship, this void also become the lungs for the building.

Within the spa, directly above the lobby space there is another void in which air (wood) penetrates through and parts the spa (earth). (Figure 5.21) The void is completely glazed with

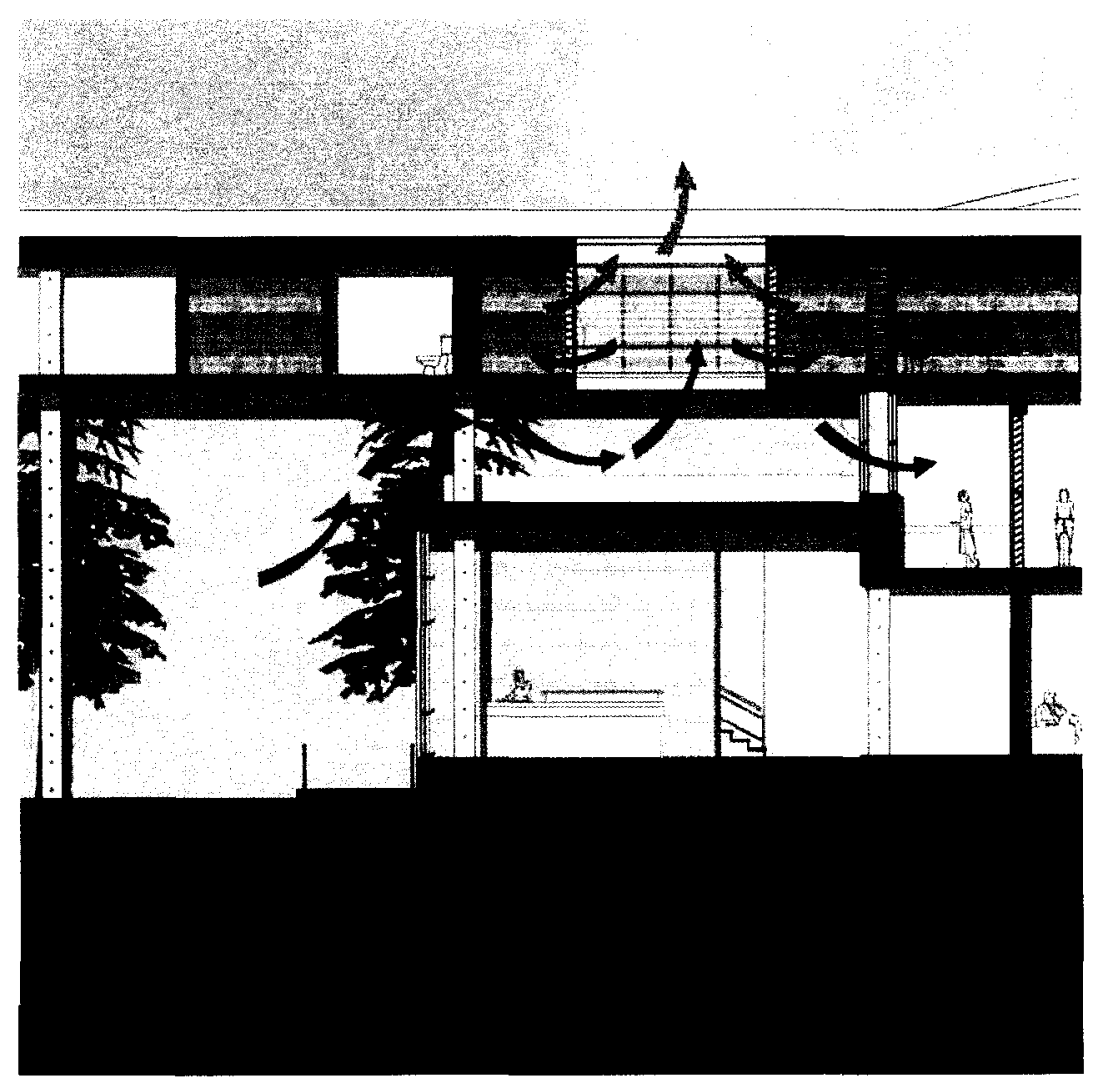

Figure 5.21 - Wood Parts Earth - Natural Ventilation operable windows allowing the warm air from within the spa to rise and exit through the void, simultaneously drawing in

a breath of fresh air. These moments where the earth and wood elements part provide opportunities for air to move and exchange air just as the lungs do. 


\subsection{Earth Absorbs Water - Light}

The relationship of earth absorbing water is established through the spaces in the earth element absorbing natural light coming from the glazed openings in the roof of the water element. The concept of absorbing something can be understood as the idea of soaking something up through pores. "There must be a crack somewhere in the construction which allows enough natural light to come in to tell how dark it is".117 Natural light pours through small slits in the ceiling and walls of the spa, continuing then to subtly pour into the hot tub, and therapeutic pool below through slits in the floor slabs and translucent glass blocks in the floor of the hot tub. (Figure 5.22 and 5.23)

Natural light is a necessity for creating a healthy environment. However the spaces of the earth element are private spaces of healing and therapy with limited exposure to the outside. The atmospheric qualities of the Thermal Baths in Vals, Switzerland designed by Peter Zumthor are similar to the qualities proposed for the healing and therapeutic components of the recreation facility. Light is carefully considered in the design of the Thermal Baths; more specifically, attention is paid to where and how it pours into the bath

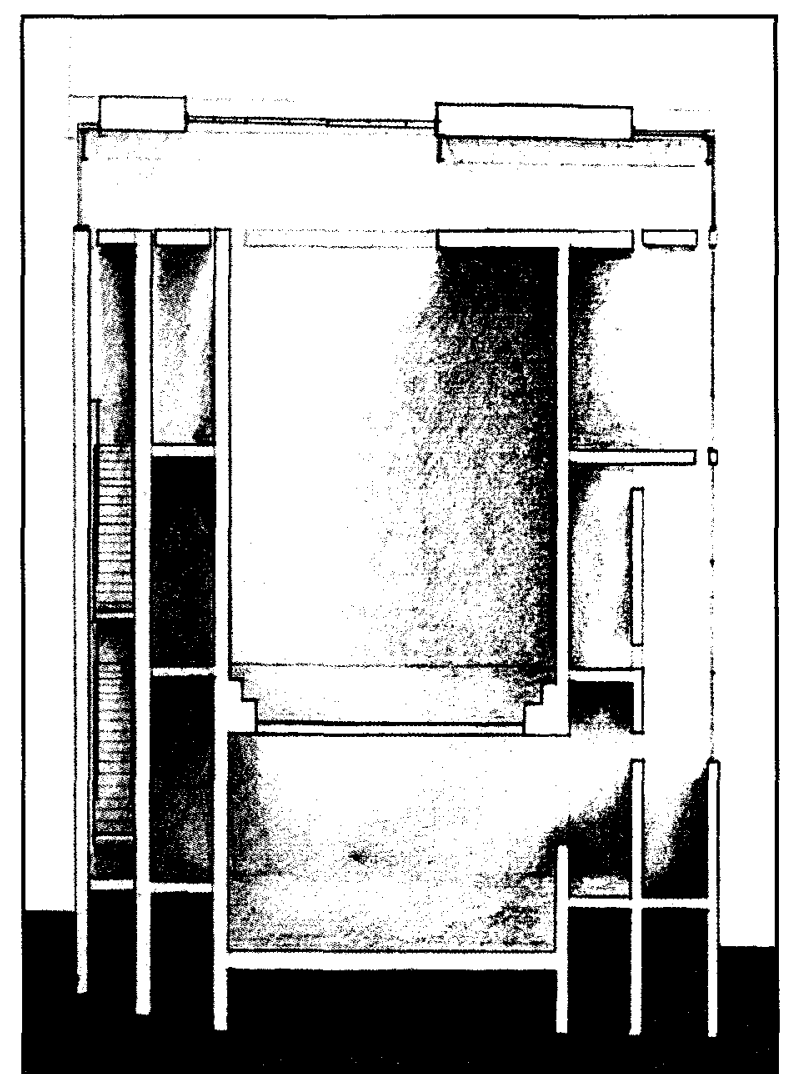

Figure 5.22 - Earth Absorbs Water Process Sketch spaces.

${ }_{117}$ Nell, E. Johnson. Light is the Theme: Louis I. Kahn and the Kimbell Art Museum. (USA: Kimbell Art Foundation, 2002), 38. 
The materiality is also

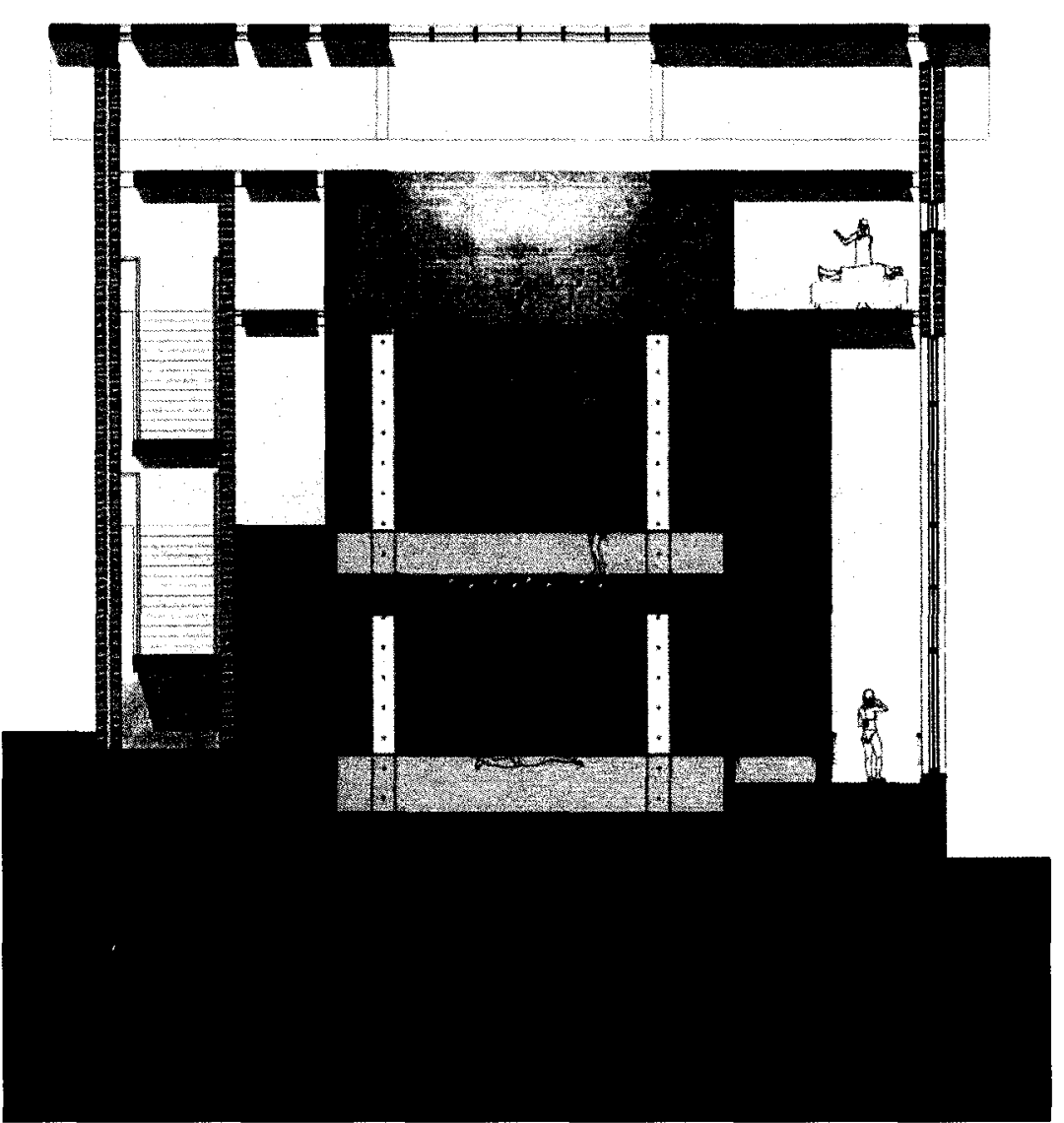

Figure 5.23 - Earth Absorbs Water - Natural Light

important as the concrete and stone offer various finishes and textures that change depending on how light touches them and influence how they are felt by the touch of a hand or foot. Figure 5.24 exemplifies the qualitative aspects of the Thermal Baths which is a precedent for the healing and therapeutic program components. One of Zumthor's strategies can best be described as, "you have to work dialectically, I mean, if you want to do something heavy you have to think about lightness, and if you want to design something dark you have to do something light as well."118 This idea of the heavy construction in the earth portion of the building made of concrete, stone, and rammed earth walls in conjunction with the subtle lightness from absorption of natural light pouring in from the roof of the overlapping swimming pool (water), creates a harmonious balance, providing a therapeutic and healthy environment.

${ }_{118}$ Steven Spier. "Place, Authorship and the Concrete: Three Conversations with Peter Zumthor," Architectural Research Quarterly 5(1) (2001): 17. 

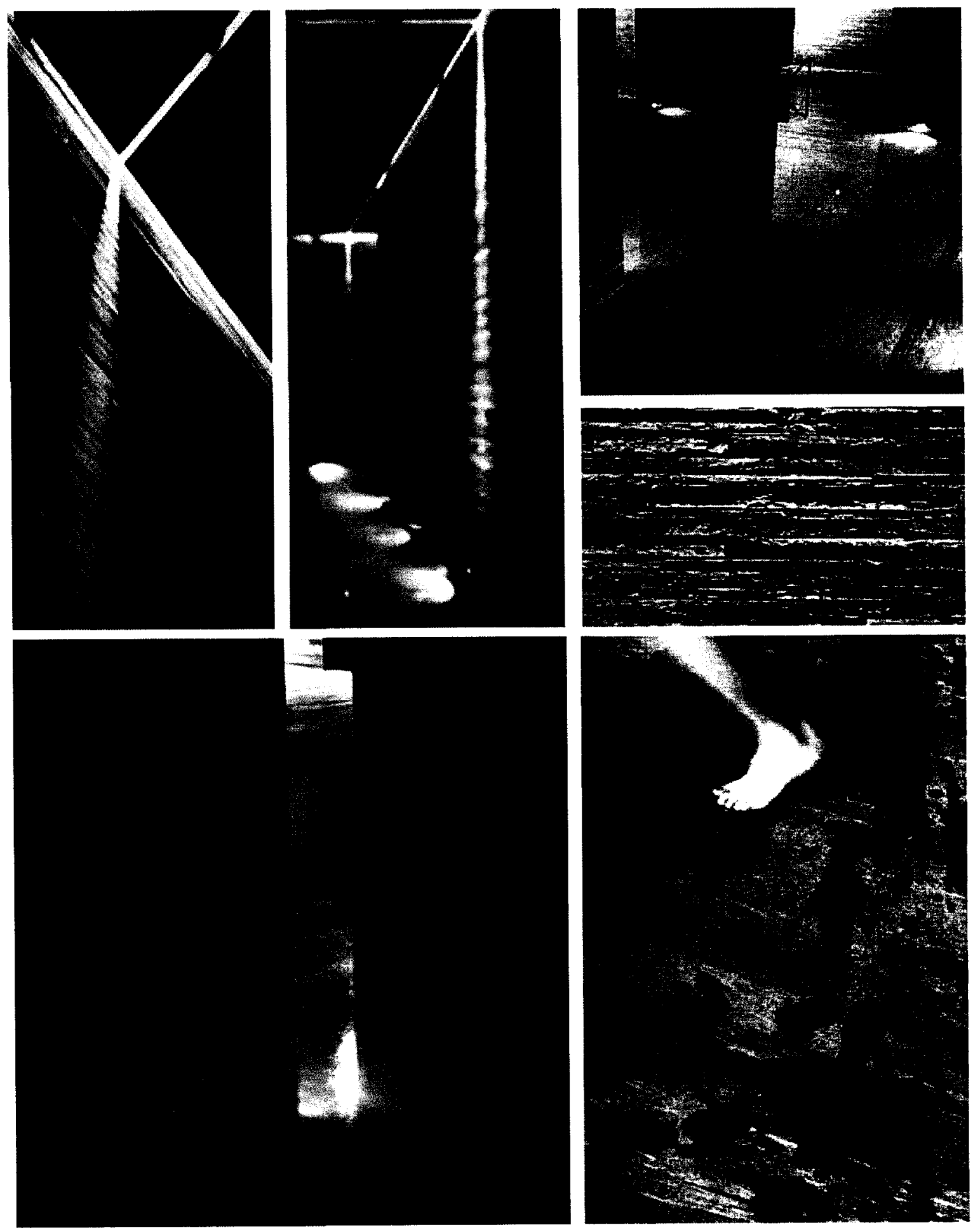

Figure 5.24 - Thermal Baths - Vals, Switzerland 


\subsection{Water Quenches Fire - Thermoactive Radiant Heating}

The water quenches fire relationship is established along the dominant south-facing wall of the recreation facility. The south-facing wall forms part of the exterior envelope for the recreation facility's change room showers (water) and for the gymnasium, squash courts, fitness center, and indoor track (fire). These "dry" activities (fire) engage the athletes in intense and heated activities, therefore providing programmatically and theoretically an opportunity for water to quench the heat created by fire.

The notion of water quenching fire is achieved through the juxtaposition of water flowing in pipes through a thick poured concrete wall, clad in black corrugated metal with southern exposure which will absorb the fire of the sun in conjunction with the mass of the concrete wall through optimizing passive solar design principles.

The cool water flowing through the tubes embedded in the concrete wall quenches the fire by suppressing the heat absorbed by through the thermal mass of the concrete wall and black corrugated metal cladding and quenches the heat by using it to warm the cool water flowing through the wall. Depending on the time of day or year, the water temperature may vary; however regardless the water will quench all of the stored heat absorbed by in the wall. The water flowing through the walls and quenching the fire will flow into an underground holding tank which will distribute the water throughout the building. Depending on the required temperature of the water for the various uses throughout the building, the water temperature may still require some adjustment through mechanical means; but reduces the overall dependence on energy consuming technologies. 
The showers in the change rooms serving the "dry activities" (fire) are strategically situated against this massive concrete wall with water flowing through it. (Figure 5.25) Additionally some of the showers are against a concrete interior wall of similar construction, also containing cast-inplace tubing with water. The water flowing through the interior wall for use in the shower has already passed through the holding tank below grade and will have had the water temperature adjusted as necessary. The water flowing through the exterior concrete wall will also be used for

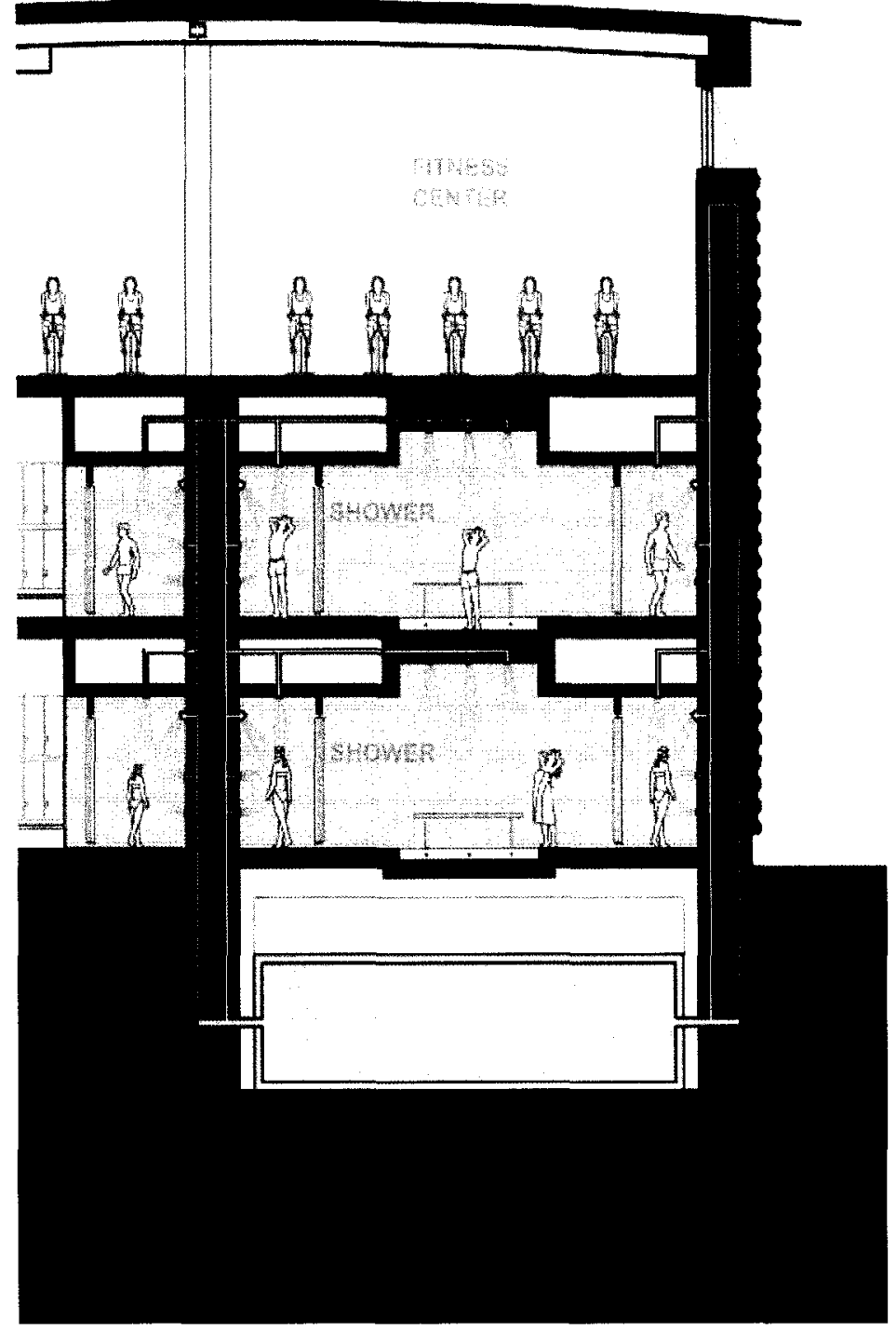

Figure 5.25 - Water Quenches Fire - Thermoactive Radiant Heating shower water, however unlike the

water moving through the interior shower wall, the temperature of this water is not adjusted and will vary in temperature based on the time of year or day. This will provide an interesting showering experience as the water may be hot, warm, or ice cold, really quenching the fire of the athletes and providing a sense of place and strong connection with the natural environment as the showering experience is dependant on the climatic conditions balanced with the material composition of the exterior wall. 


\subsection{Fire Melts Metal - Light}

The fire melts metal relationship is established through a large atrium that intersects through the squash courts and fitness center (fire) and terminating on the ground level in the classrooms and meeting rooms (metal). Most areas of the recreation facility are exposed to natural light with the exception of these meeting rooms and classrooms. This atrium allows for light to penetrate deep through building, reflecting and spreading natural light into these spaces. (Figure 5.26)

The concept of melting is concerned with

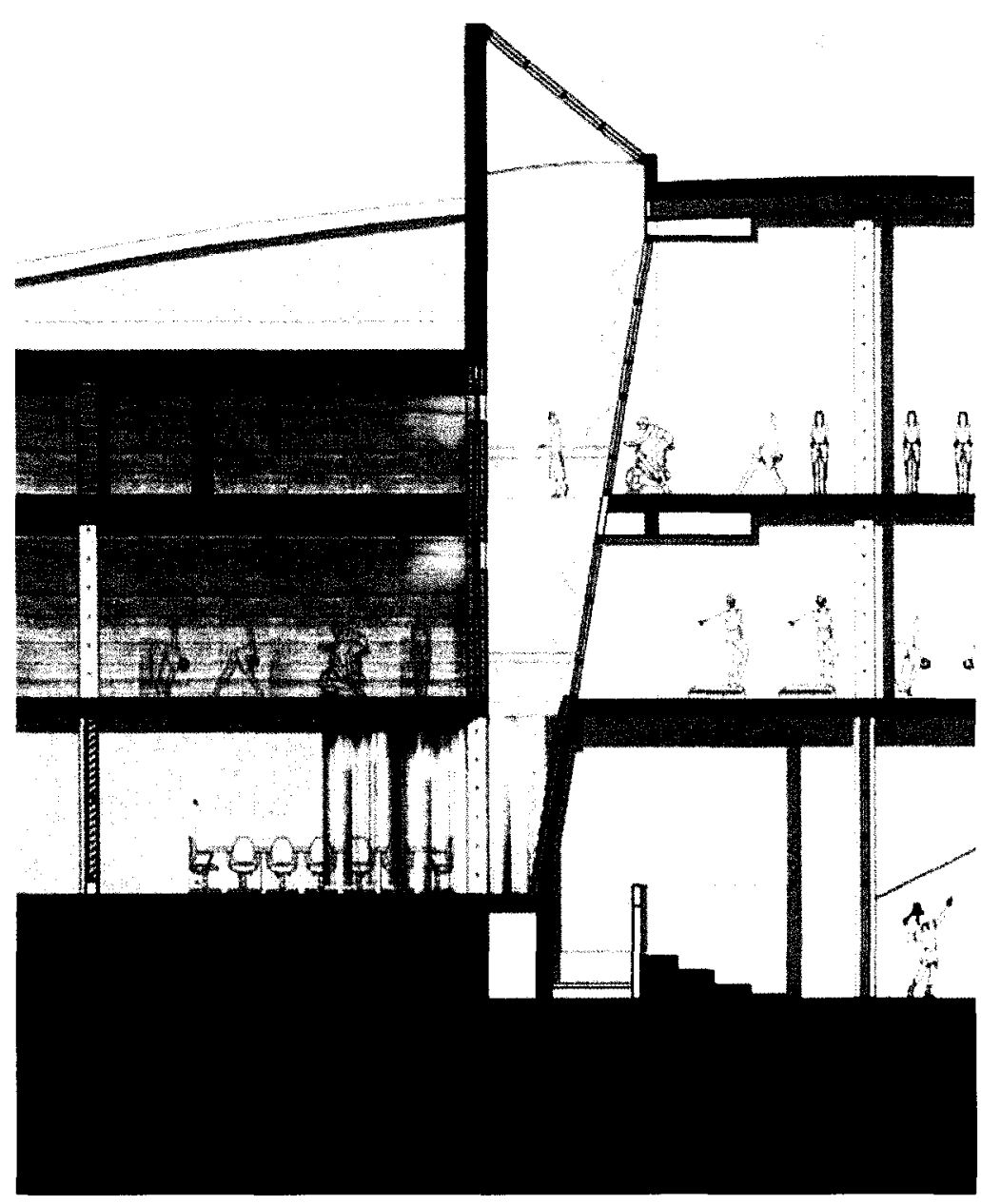

Figure 5.26 - Fire Melts Metal - Light notion of something gradually changing, and transforming. To establish the fire melts metal relationship in this narrow slit to the sky, light, a qualitative aspect of the fire element is used to perceptually me/t the metal cladding on the ground floor atrium walls of the meeting rooms and classrooms by changing and transforming the metal via light throughout the day and year. 
The atrium is oriented towards the south with glazing on the east and west faces as well. The angle of the atrium captures the sunlight for most of the day and year. The light that enters the atrium is reflected off of a polished concrete wall, above the rammed earth wall of the spa, and directs the natural light towards the bottom of the atrium where it will come in contact with the copper and nickel metal wall.

As the sun moves throughout the day and year, changing amounts of light interacting with the two different metals on the wall will result in varying conditions ranging from dark to light, shiny to matte, and reflective to dull, providing a greater understanding of the time of day and year. "Natural light has all the moods of the time of the day, the seasons of the year, [which] year for year and day for day are different from the day preceding". ${ }^{119}$

The atrium is a healthy design solution as it brings natural light deep into the building; making the users aware of the changing environmental conditions through the transformations that occur in the dynamic metal wall through the reflections of the natural light.

119 Nell, E. Johnson. Light is the Theme: Louis I. Kahn and the Kimbell Art Museum. (USA: Kimbell Art Foundation, 2002), 18. 


\subsection{Metal Splits Wood - Thermodynamic Heating}

The metal splits wood relationship is expressed in the design of the proposed recreation facility through the large air filled volumes (metal) ${ }^{120}$ splitting through the west corridor of the building and the pipes splitting through the concrete floor of the change rooms (wood).

Fresh air from the breezes blowing through the courtyard enters into the large steel pipes that are splitting through the earth gasping for air. The air enters the steel pipes which burst through the reflecting pond in the courtyard, and through a deep breath the air flows underground into clay tubes that carry the air into the underground lung (heat exchanger) that is located below the west corridor of the building. During this process, based on the principles of thermodynamic heating ${ }^{121}$,

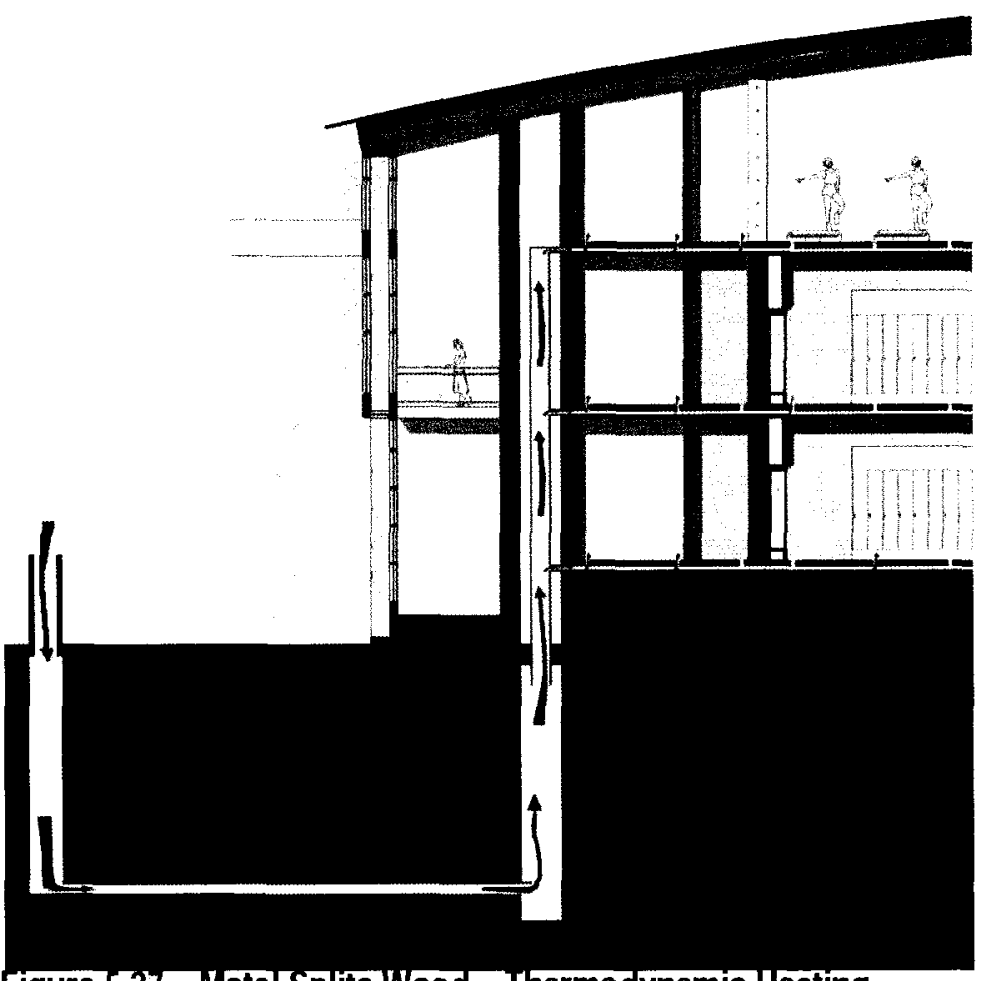

Figure 5.27 - Metal Splits Wood - Thermodynamic Heating

the more or less constant temperature of the earth warms or cools the air flowing through the clay tubes, requiring only minimal additional warming or cooling. ${ }^{122} \quad$ From the underground lung the air is transported to the buildings bloodstream (ventilation system) and the air continues through a large tube enclosed in a

\footnotetext{
120 In the Five Elements Theory, the lung is the organ of the metal element which is associated with air, therefore the large air filled volumes are considered to represent the metal element.

121 The principles of a thermodynamic heating system is based on extracting the exterior air and using heat energy stored in the soil to naturally heat or cool the internal air, simultaneously naturally ventilating the internal air. Dominique Gauzin-Muller. Sustainable Architecture and Urbanism: Concepts, Technologies, Examples. (Basel: Birkhauser, 2002), 94.

122 Ibid., 94.
} 
concrete volume, which is connected to smaller tubes that are cast into the concrete floor and subtly split through the slab at various locations distributing the naturally ventilated air that started out as a breeze moving through the courtyard into the corridor and change rooms. (Figure 5.27) The used air is taken out through a separate system. Figure 5.28 demonstrates how the tubes penetrate through the concrete floors.

This respiratory system of the building (thermodynamic heating) is a sustainable and viable method to regulate internal air temperature throughout the year. The distance between the airintake tube in the courtyard and the interior air tubes is just over fifty meters in length. If the tube coils through the ground to reach a total length of one hundred meters before entering the building, then the internal air can be cooled by seven degrees Celsius in the summer and heated by seven degrees Celsius in the winter, providing significant temperature differences. ${ }^{123}$ In addition to controlling the internal temperature this process provides naturally ventilated air into the building which important for the change rooms as they are subject to various internal climatic and temperature differences.

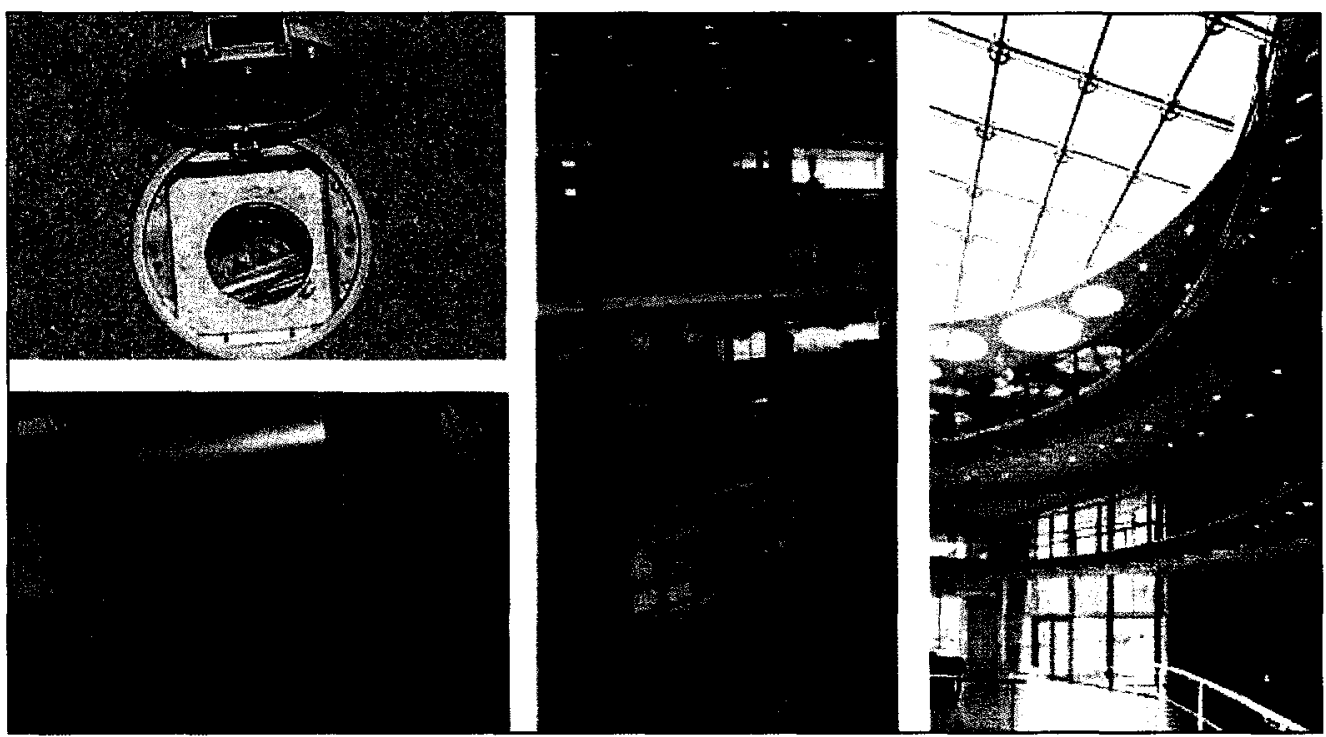

Figure 5.28 - Thermodynamic Heating System - IT Offices, Germany

${ }^{123}$ Dominique Gauzin-Muller. Sustainable Architecture and Urbanism: Concepts, Technologies, Examples. (Basel: Birkhauser, 2002), 94. 


\section{Conclusion}

This thesis raises the question of whether buildings can be "healthy". The growth and strength of the green building movement has encouraged awareness about the imperative role that architecture has to re-establish a dialogue between the built environment and nature, and the consequences of a callous disregard for the health in the built environment. The green building movement focused mainly on the technological aspects of design; therefore creating many buildings that were successful in reducing their energy consumption but lacked in a broader sense regarding the qualitative aspects of architecture and the architectural connection to nature.124 "Bridging the pragmatic and transcendent, architecture can play both a practical and symbolic role in the development of a carefully attuned cultural response to the larger paradigmatic movement of sustainability." 125

Through the design of the recreation facility, this thesis demonstrates the capacity for architecture to create a healthy built environment and forms a critical position that there is an architectural responsibility to do so. It is argued that this thesis does achieve a "healthy" building, re-establishing a dialogue between architecture and nature; in both the formal manifestation of the building and in the design process, through the concept of balance and harmony which have a fundamental theoretical premise in the Five Elements Theory and traditional Chinese medicine.

While the use of the ancient philosophical basis for traditional Chinese science; the Five Elements, may initially seem like an incongruous concept to advance contemporary sustainability, this thesis project has discovered the opposite. Going beyond the conventional technological perception of sustainability, the Chinese Five Elements and the Cycle of Balance are integrated into the design of the recreation facility, introducing a broader dialogue with fundamental

\footnotetext{
124 John McMinn and Marco Polo. $41^{\circ}$ to $66^{\circ}$ Regional Responses to Sustainable Architecture in Canada. (Cambridge, Ontario: Design at Riverside, 2006), 3.

125 Ibid., 3.
} 
environmental ideas into the unpredictable layers of the process of architectural design. The healthy design strategies that evolved in the design of the recreation facility are not new, but rather build upon the prevailing environmental technology, integrating them architecturally in a holistic approach according to the principles of the Five Elements which are abstracted through the architecture to form a unique relationship with nature. This in turn has fundamentally changed the 'predictable' and typical outcome for this building typology in a positive manner, creating a "healthier" built environment. "Human life is not intended to oppose nature and endeavor to control it, but rather to draw nature into an intimate association in order to find union with it."126

In addition to this thesis addressing the concern of health through healthy design strategies, a sensibility and appreciation of nature is established through the various sensuous experiences that are developed through the design solutions; the touch and sound of water, the reflection of metal and light, the smell of wood, the touch of earth, the warmth of the sun, and a breath of fresh air that will inevitably synthesize a healthy environment and sustainable future.

"There is no clear demarcation between outside and inside, but rather their mutual permeation. Today, unfortunately, nature has lost much of its former abundance, just as we have enfeebled our ability to perceive nature. Contemporary architecture, thus, has a role to play in providing people with architectural places that make them feel the presence of nature. ${ }^{\prime 127}$

Tadao Ando

\footnotetext{
126 Tadao Ando. "Toward New Horizons in Architecture", in: Kate Nesbitt, Theorizing a New Agenda for Architecture. (New York: Princeton Architectural Press, 1996), 460.

127 lbid., 460.
} 


\section{Bibliography}

Ando, Tadao. "Toward New Horizons in Architecture" in: Kate Nesbitt, Theorizing a New Agenda for Architecture. New York: Princeton Architectural Press, 1996.

Baker, Nick and Koen Steemers. Energy and Environment in Architecture: A Technical Design Guide. New York: Routledge, 2000.

Bob Chiarelli for Mayor. Bob's Vision: Chiarelli to Reclaim Bayview Yards A Community Green Space, November 8, 2006, <http://www.bobchiarelli.com/mayor_of_ottawa/04_vision_e.html> (accessed October 1, 2007).

Bramble, Cate. Architect's Guide to Feng Shui: Exploding the Myth. Amsterdam: Architectural Press, 2003.

Bregman + Hamann Architects, Queens University - Beamish-Munro Hall, 2008 $<w w w . b h a r c h i t e c t s . c o m>$ (accessed February 24, 2008).

Busby, Peter and Jim Taggart. Busby: Learning Sustainable Design. Quebec: Janam Publications Inc., 2007.

City of Ottawa. The Brownfields Context, 2008

$<$ http://www.ottawa.ca/residents/planning/brownfields/introduction/context_en.html> (accessed November 2007).

City of Ottawa. Surveys and Mapping. Air Photos, 2005: 1:15,000. [computer file]. Ottawa, City of Ottawa, 2005.

Diane Holmes, New Developments, 2007

$<$ <ttp://www.dianeholmes.ca/new_developments_detail.php?id=31>(accessed October 2007).

Gadamer, Hans-Georg. The Enigma of Health. California: Stanford University Press, 1996.

Gauzin-Muller, Dominique. Sustainable Architecture and Urbanism: Concepts, Technologies, Examples. Basel: Birkhauser, 2002.

Gernot, Minke. Building with Earth: Design and Technology of a Sustainable Architecture. Boston: Birkhauser Publishers for Architecture, 2006.

Godish, Thad. Sick Buildings: Definition, Diagnosis and Mitigation. USA: CRC Press Inc. 1995.

Guenther, Robin and Gail Vittori. Sustainable Healthcare Architecture. New Jersey: John Wiley \& Sons, Inc., 2008.

Haden, Bruce and Brady Dunlop. "Terra Firma," Canadian Architect 52 (3) (2007): 32-33 
Hoizey, Dominique and Marie-Joseph. A History of Chinese Medicine. Translated by Paul Bailey. Vancouver: UBC Press, 1993.

Hotson Bakker Boniface Haden Architects and Urbanistes, Nk'Mip Desert Cultural Center, $<w w w . h b b h a r c . c o m>$ (accessed February 24, 2008.)

Jen, Leslie. "Green Machine [Integrated Learning Centre at Beamish-Munro Hall]," Canadian Architect 50 (1) (2007): 16-18.

Jenkins, Phil. An Acre of Time. Toronto: Macfarlane Walter \& Ross, 1996.

Johnson, Nell, E. Light is the Theme: Louis I. Kahn and the Kimbell Art Museum. USA: Kimbell Art Foundation, 2002.

McDonell, Geoff. "Radiant Solutions," Canadian Architect 48 (3) (2003): 38-39.

McMinn, John and Marco Polo. $41^{\circ}$ to $66^{\circ}$ Regional Responses to Sustainable Architecture in Canada. Cambridge, Ontario: Design at Riverside, 2006.

Northern Shaolin Academy. Five Elements Chart, 2007, $<$ http://www.northernshaolinacademy.com/new/NsaQigongMeditationFiveElements.asp > (accessed November 16, 2007).

O'Donoghue, Sarah, "Chiarelli has a Green Plan for Bayview Yards," Ottawa Citizen, November 9 , 2006.

Qizhi, Zhang. Traditional Chinese Culture. Beijing: Foreign Languages Press, 2004.

Queens University and the contributors, Biowall, 2006,

$<\mathrm{http}: / /$ ivebuilding.queensu.ca/green_features/biowall> (accessed November 23, 2007).

Rossbach, Sarah. Feng Shui: The Chinese Art of Placement. New York: Penguin Books USA Inc., 1983.

Rossbach, Sarah. Interior Design with Feng Shui. New York: Penguin Books USA Inc., 1987.

Smith, Vincent M. and Barbara Lyons Stewart. Feng Shui: A Practical Guide for Architects and Designers. USA: Kaplan Professional, 2006.

Spier, Steven. "Place, Authorship and the Concrete: Three Conversations with Peter Zumthor," Architectural Research Quarterly 5 (1) (2001): 15-36.

Thakre, Peeroj. "Earth and Sky," Canadian Architect 52 (3) (2007): 26-30 
Wu, Laurence C. Fundamentals of Chinese Philosophy. USA: University Press of America, Inc., 1986.

Zumthor, Peter. Peter Zumthor Works: Buildings and Projects 1979 - 1997. Basel: Birkhauser Publishers for Architecture, 1999.

Zynda, Todd. EnviroTools: Michigan State University and National Institute of Environmental Health Sciences. Phytoremediation, 2001,

$<$ <ttp://www.envirotools.org/factsheets/phytoremediation.html> (accessed January 23, 2008). 


\section{Appendix A: Tables}

Table 1.1 Five Elements Chart

\begin{tabular}{|l|l|l|l|l|l|}
\hline ELEMENT & WOOD & FIRE & EARTH & METAL & WATER \\
\hline Cycle of & Feeds Fire & Creates Earth & Bears Metal & Collects Water & Nourishes Wood \\
& Parts Earth & Melts Metal & Absorbs Water & Splits Wood & Quenches Fire \\
\hline Compass & East & South & Center & West & North \\
Direction & Upward & Upward & Stable & Inward & Downward \\
Seasons & Spring & Summer & Changing & Autumn & Winter \\
Planet & Jupiter & Mars & Saasons & Venus & Mercury \\
Senses & Sight & Touch & Taste & Smell & Sound \\
Action & Crushing & Exploding/Pounding & Crossing & Splitting & Drilling \\
Organ & Liver & Heart & Spleen & Lung & Kidney \\
Time & Sunrise & Noon & Between & Sunset & Midnight \\
Climate & Windy & Heat & Damp & Dry & Wet \\
Colour & Green & Red & Yellow & White/Gray & Blue/Black \\
Motion & Expansive & Intense & Firm & Heavy & Fluid \\
Material & Wood/Plants & Light & Rock/Stone & Metal & Water/Glass \\
Activity & Walk & Look & Sit & Lay & Stand \\
Tissue & Tendons & Arteries & Muscles & Skin & Bones \\
Stages & Birth & Growth & Transformation & Harvest & Storage \\
Position & Back & Right & Center & Forward & Left \\
Shape & TallNertical & Pointed/Triangle & Low/Horizontal & Spherical/Hard & Wavy/Reflective \\
Yin/Yang & Minimum Yang & Maximum Yang & Neutral & Minimum Yin & Maximum Yin \\
\hline
\end{tabular}

This is a selective list of the qualative aspects of the Five Elements Theory. 
Table 1.2 Yin and Yang Chart

\begin{tabular}{|ll|}
\hline Qualities of Yang & Qualities of Yin \\
\hline Above & Below \\
Intensity & Persistence \\
Back side & Front side \\
Bright & Dark \\
Day & Night \\
Dry & Wet \\
East & West \\
Expand & Contract \\
Fast & Slow \\
Features of landscape & Retained water \\
Fire & Water \\
Fly & Walk \\
Function & Structure \\
Generate & Grow \\
Hard & Soft \\
immaterial & Material \\
Intentionality & Passivity \\
Left & Right \\
Noisy & Quiet \\
Noon & Midnight \\
North of the ecliptic & South of the ecliptic \\
Outside & Inside \\
Produce Energy & Produce form \\
Qi' & Fluids \\
Rapid & Gradual, lingering \\
Restive & Still \\
Rise & Descend \\
Round & Flat \\
Smooth & Rough \\
South & North \\
Summer solstice & Winter solstice \\
Sun & Moon \\
Time & Space \\
& \\
\hline
\end{tabular}

' $Q i$ can refer to the activity of life (and to the traditional mind life is an aspect of being). It can also refer to mood or an active influence (perhaps something auditory, atmospheric, bacterial, viral, or chemical). In Chinese science, numbers along with principles and qi describe and direct how nature functions. 
Table 4.1 Recreation Facility Program

\section{RECREATION FACILITY PROGRAM}

\begin{tabular}{|c|c|c|c|c|}
\hline "Wet" Activities & "Dry" Activities & $\begin{array}{l}\text { Healing and } \\
\text { Therapeutic } \\
\text { Activities }\end{array}$ & $\begin{array}{l}\text { Common } \\
\text { Spaces }\end{array}$ & $\begin{array}{l}\text { Support } \\
\text { Spaces }\end{array}$ \\
\hline $\begin{array}{l}\text { Lap Pool } \\
\text { Diving Pool } \\
\text { Children's Pool } \\
\text { Showers }\end{array}$ & $\begin{array}{l}\text { Gymnasium } \\
\text { Squash Courts } \\
\text { Indoor Track } \\
\text { Fitness Centre } \\
\text { Tennis Courts }\end{array}$ & $\begin{array}{l}\text { Spa } \\
\text { Therapeutic Pool } \\
\text { Hot Tub } \\
\text { Sauna } \\
\text { Physiotherapy } \\
\text { First Aid Room }\end{array}$ & $\begin{array}{l}\text { Lobby / Lounge } \\
\text { Changeroom / } \\
\text { Locker Room } \\
\text { Restaurant / Café } \\
\text { Rental Store } \\
\text { Retail Store } \\
\text { Link to O-Train }\end{array}$ & $\begin{array}{l}\text { Offices } \\
\text { Classrooms } \\
\text { Meeting Rooms } \\
\text { Washrooms } \\
\text { Storage } \\
\text { Housekeeping } \\
\text { Mech./Elect. } \\
\text { Rooms }\end{array}$ \\
\hline
\end{tabular}

Table 4.2 Building Orientation

\section{BUILDING ORIENTATION}

\begin{tabular}{|l|l|}
\hline Element & Compass Direction \\
\hline Wood & East \\
Fire & South \\
Earth & Center \\
Metal & West \\
Water & North \\
\hline
\end{tabular}


Table 5.1 Cycle of Balance Related to Recreation Program

\section{CYCLE OF BALANCE}

Related program components in italics adjacent to its corresponding element.

\section{Creation / Generating Cycle}

Wood (Common Spaces) feeds Fire ("Dry"

Activities)

Fire ("Dry" Activities) creates Earth (Healing and Therapeutic Activities)

Earth (Healing and Therapeutic Activities) bears Metal (Support Spaces)

Metal (Support Spaces) collects Water ("Wet" Activities)

Water ("Wet" Activities) nourishes Wood (Common Spaces)

\section{Destruction / Overcoming Cycle}

Wood (Common Spaces) parts Earth (Healing and Therapeutic Activities) Earth (Healing and Therapeutic Activities) absorbs Water ("Wet" Activities)

Water ("Wet" Activities) quenches Fire ("Dry" Activities)

Fire ("Dry" Activities) melts Metal (Support Spaces)

Metal (Support Spaces) splits Wood (Common Spaces) 
Appendix B: Plates

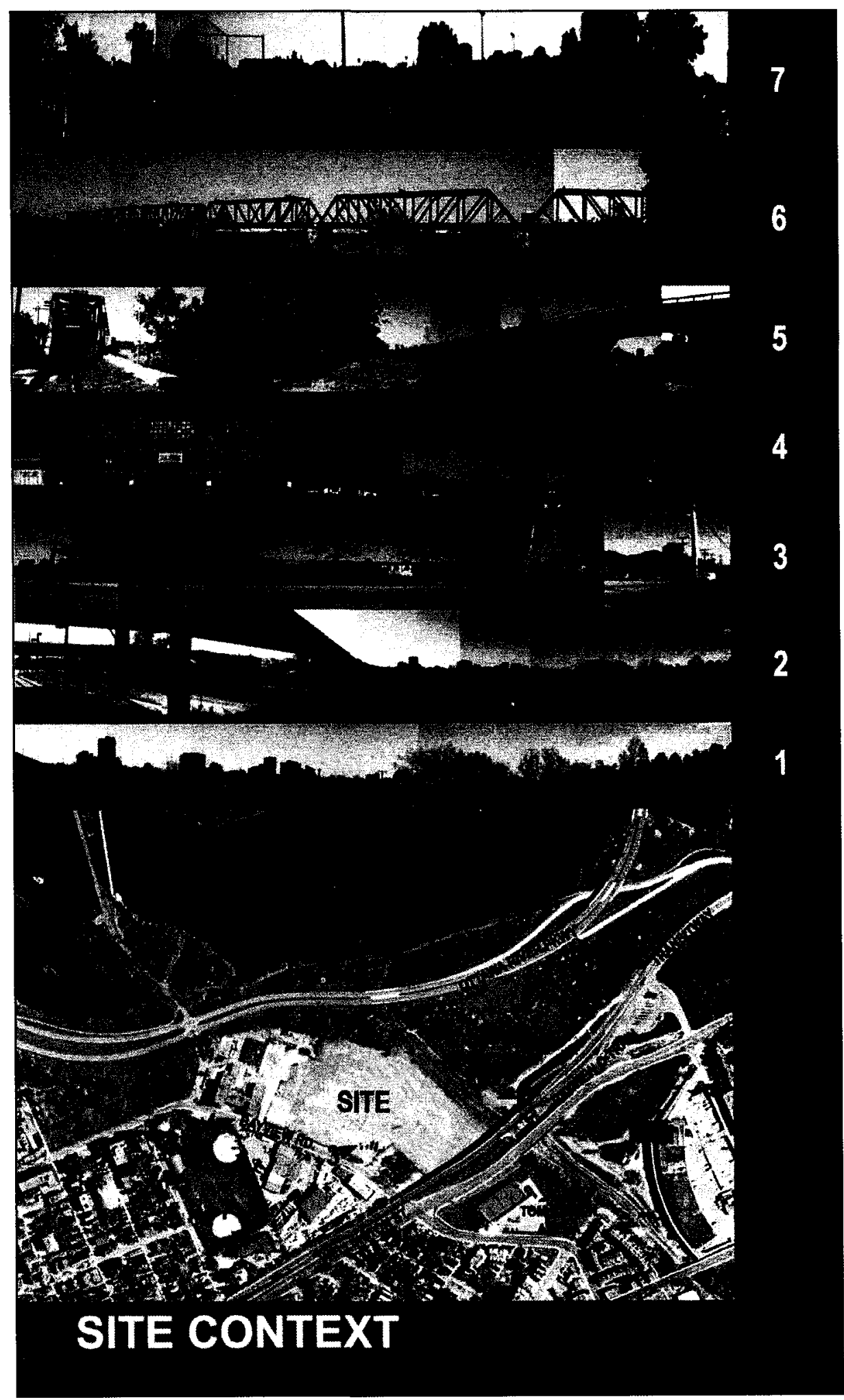

Plate 1 Site Context Images and Current Site Plan 


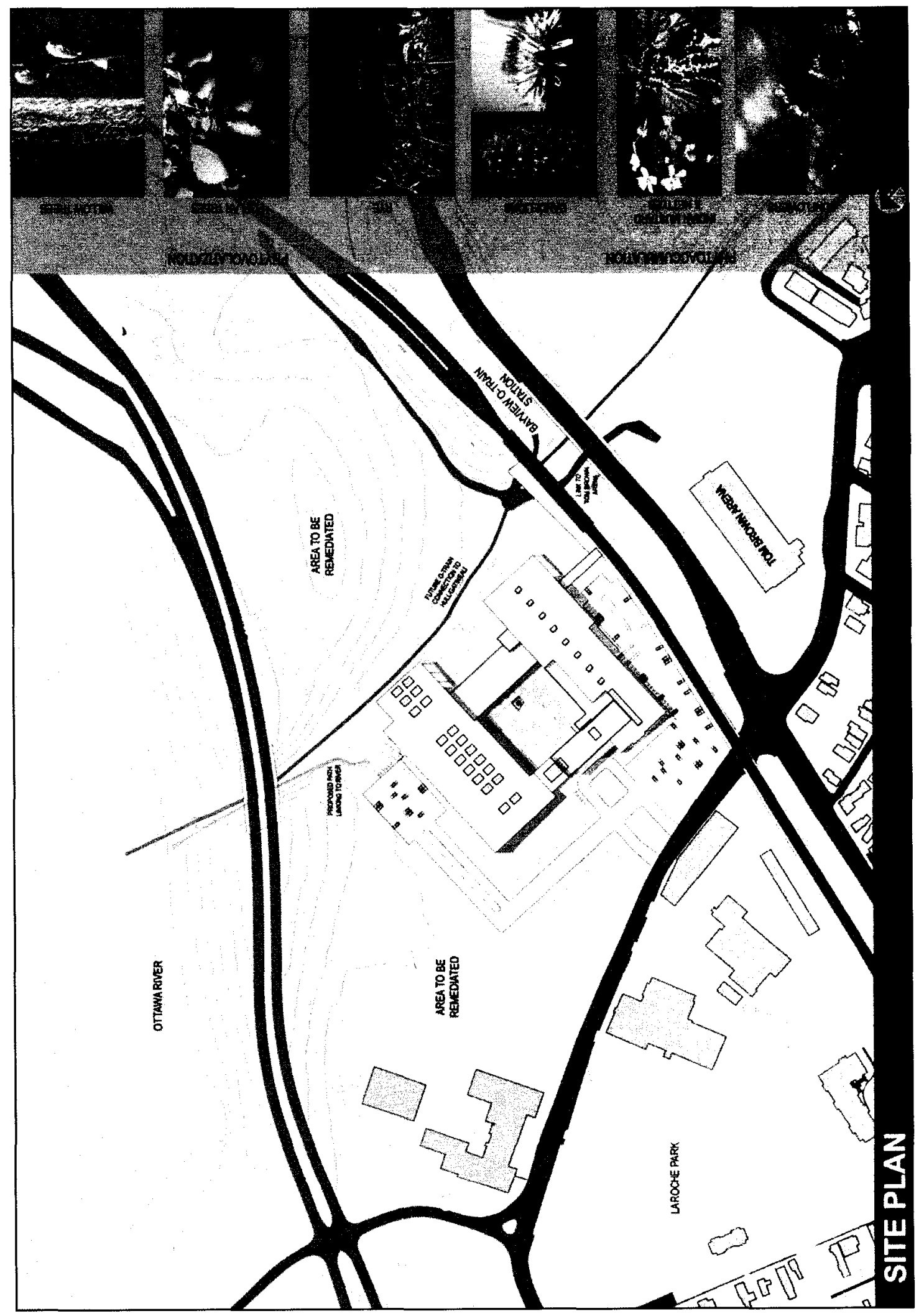

Plate 2 Site Plan 


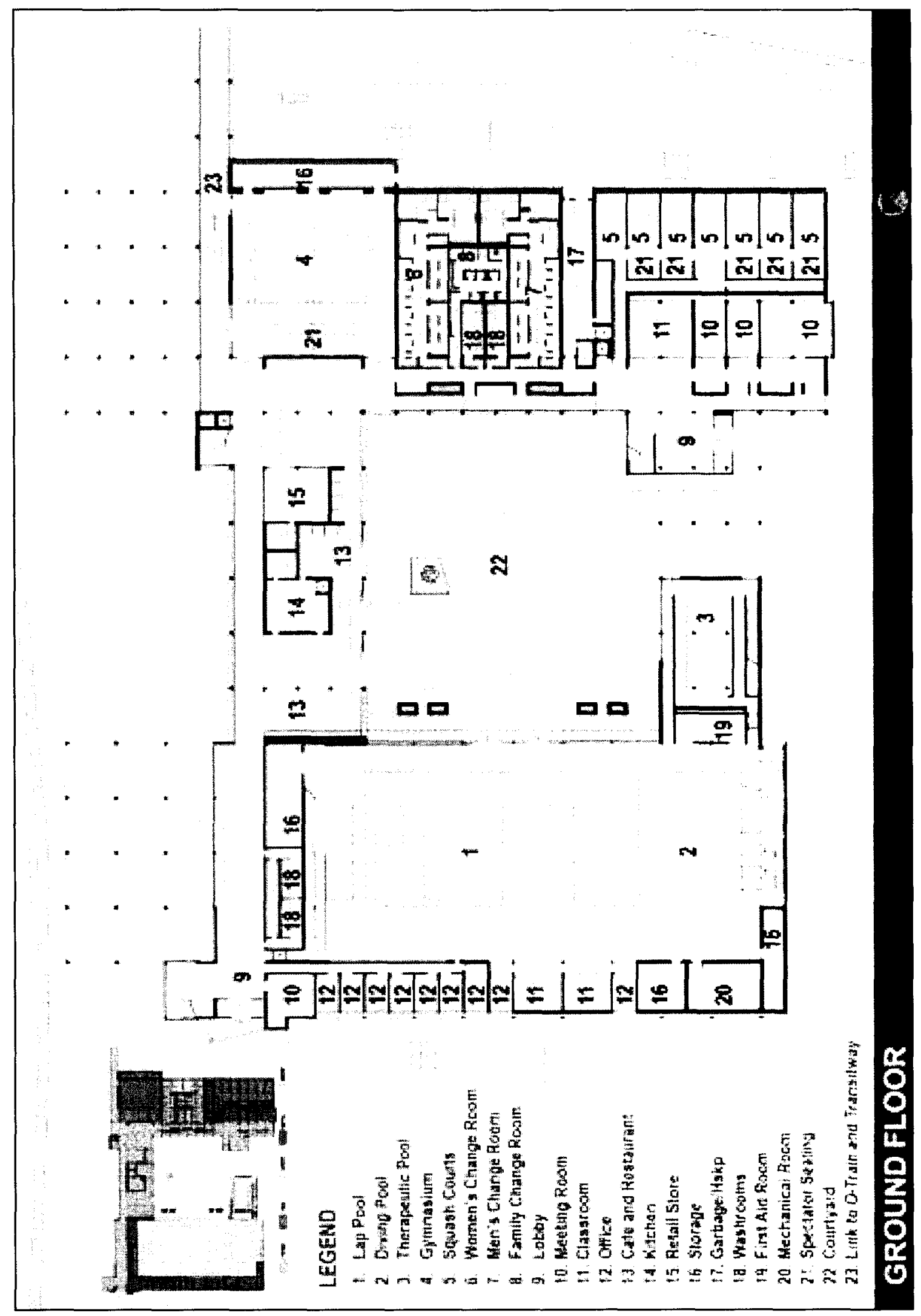

Plate 3 Ground Floor Plan 


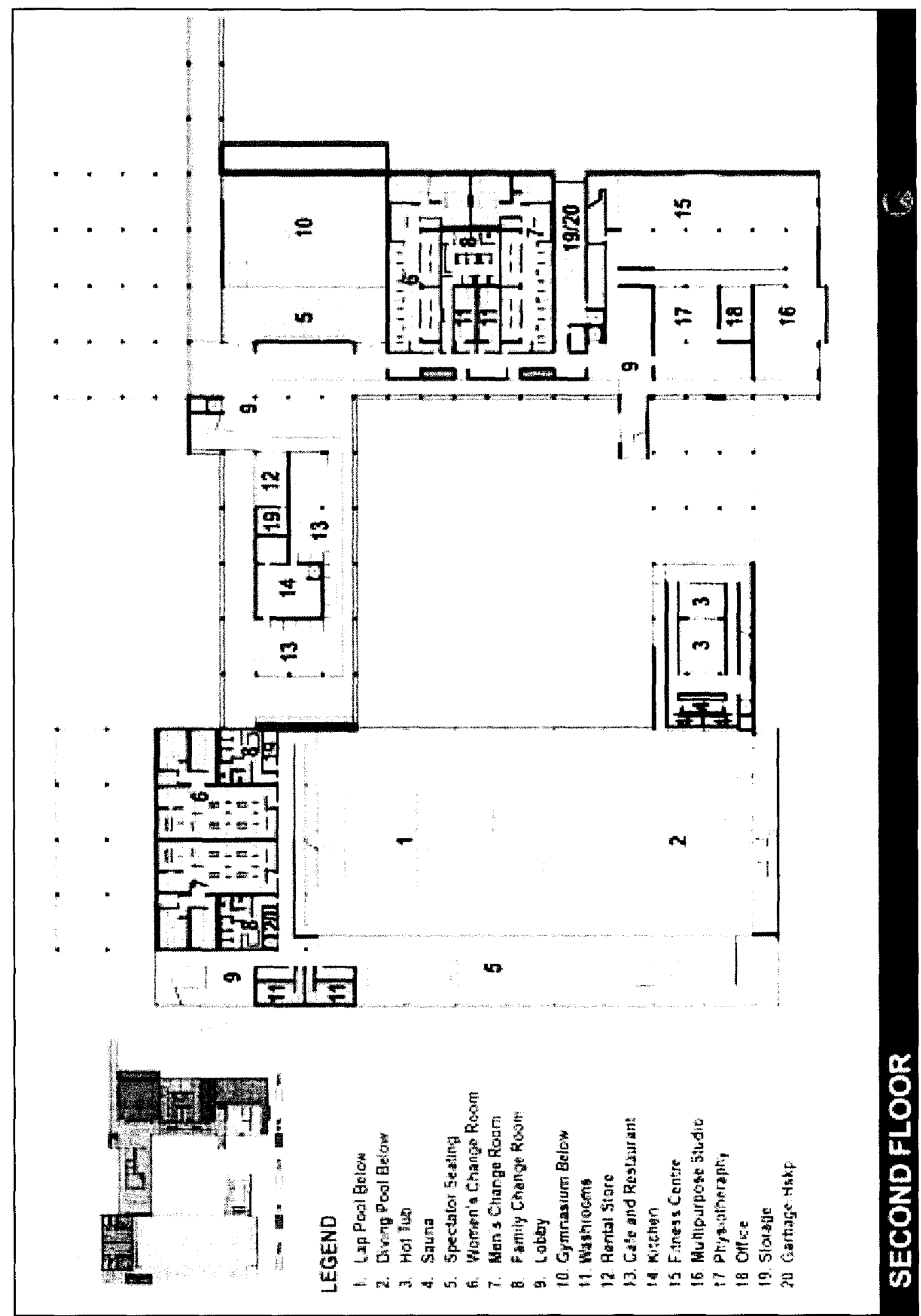

Plate 4 Second Floor Plan 


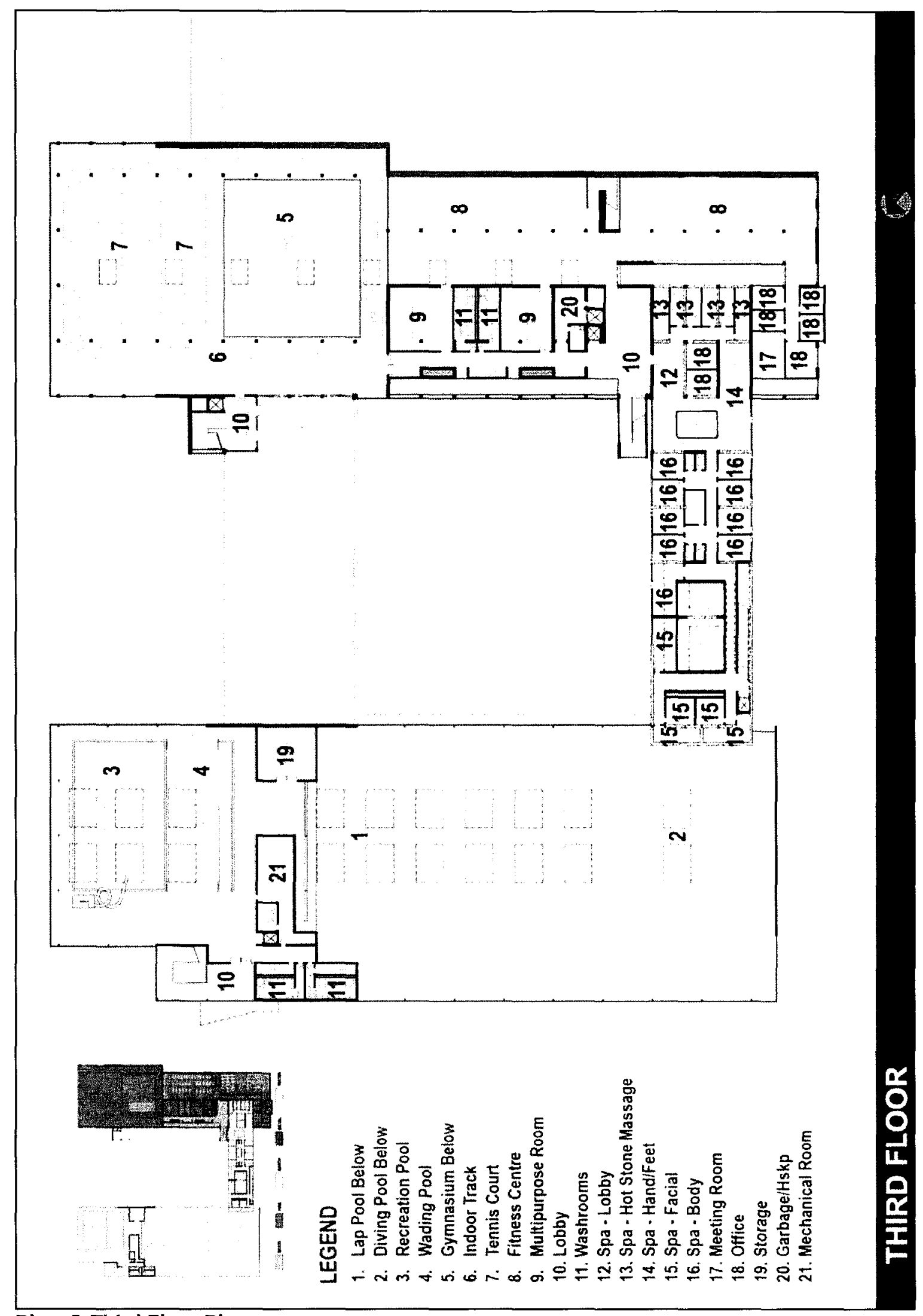

Plate 5 Third Floor Plan 


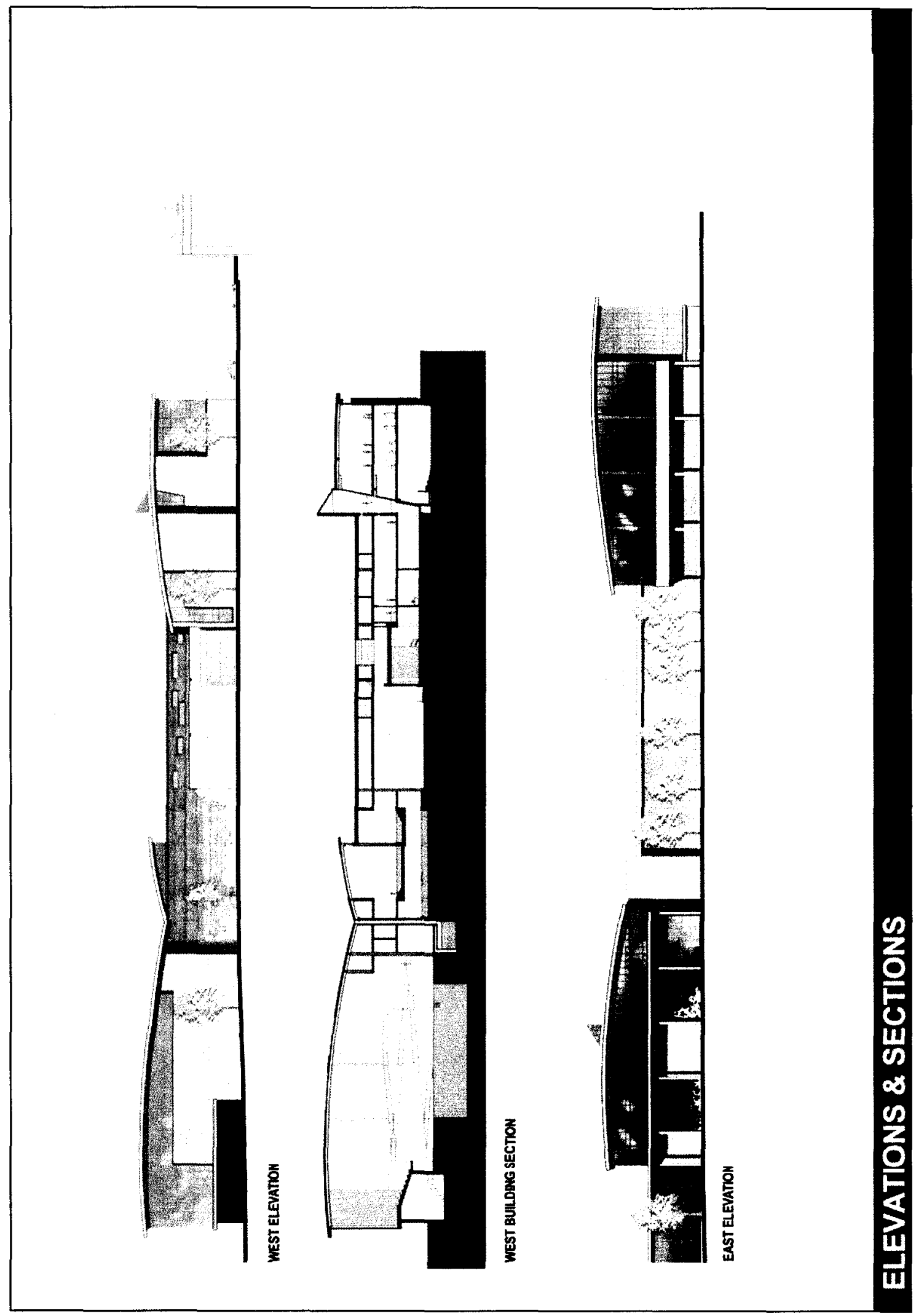

Plate 6 Building Elevations and Sections 


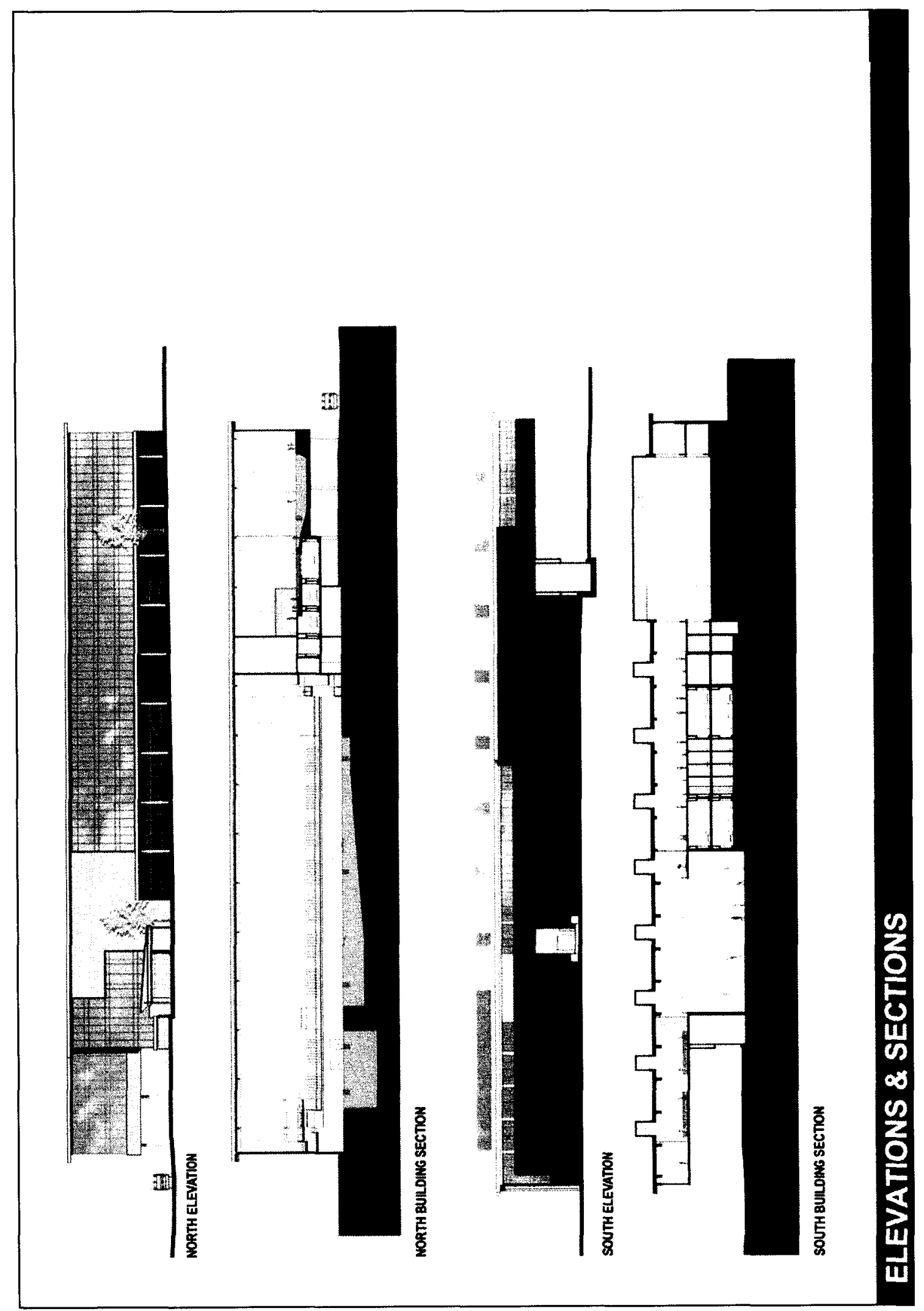

Plate 7 Building Elevations and Sections 


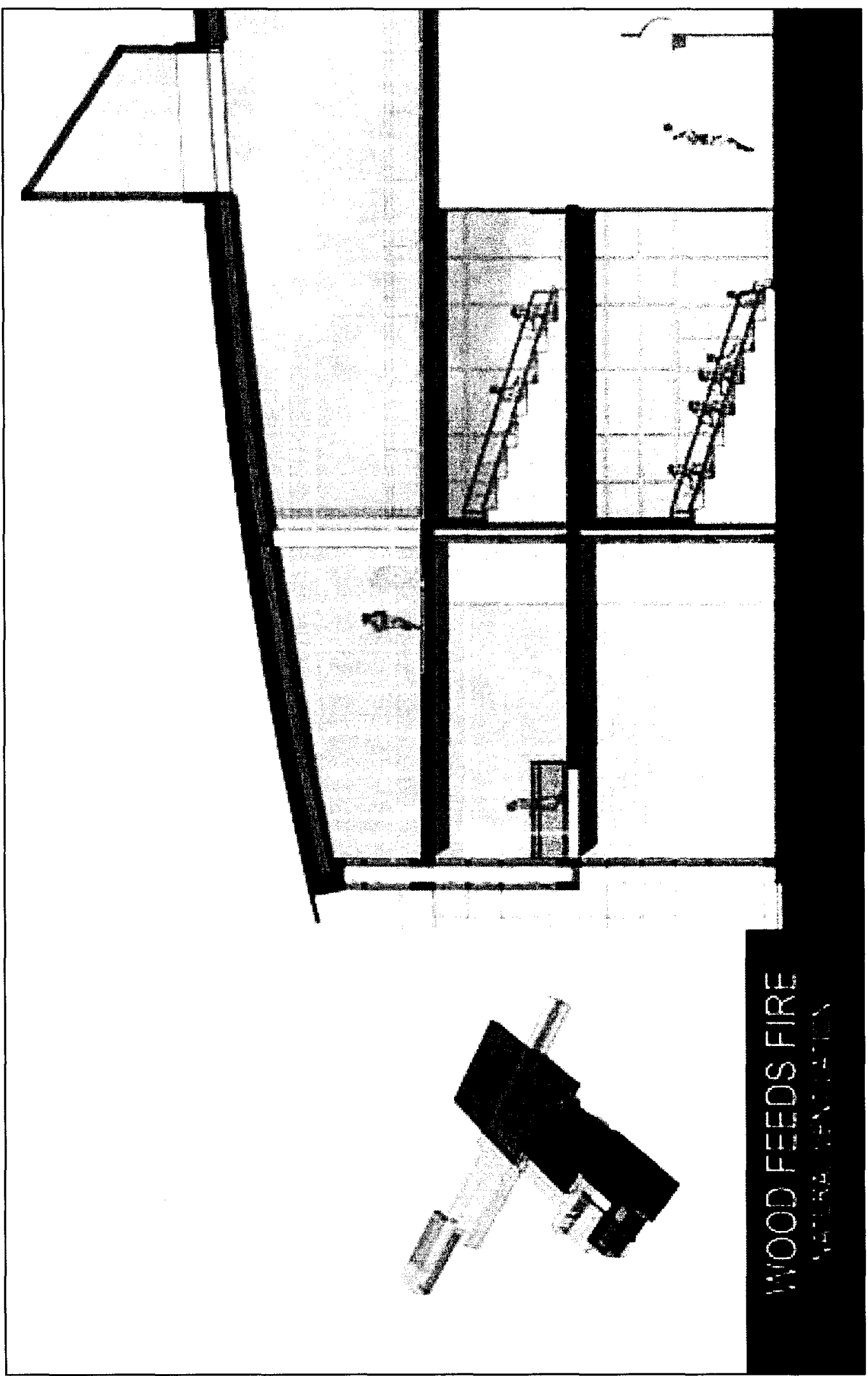

Plate 8 Detail Section 1: Wood Feeds Fire - Natural Ventilation 


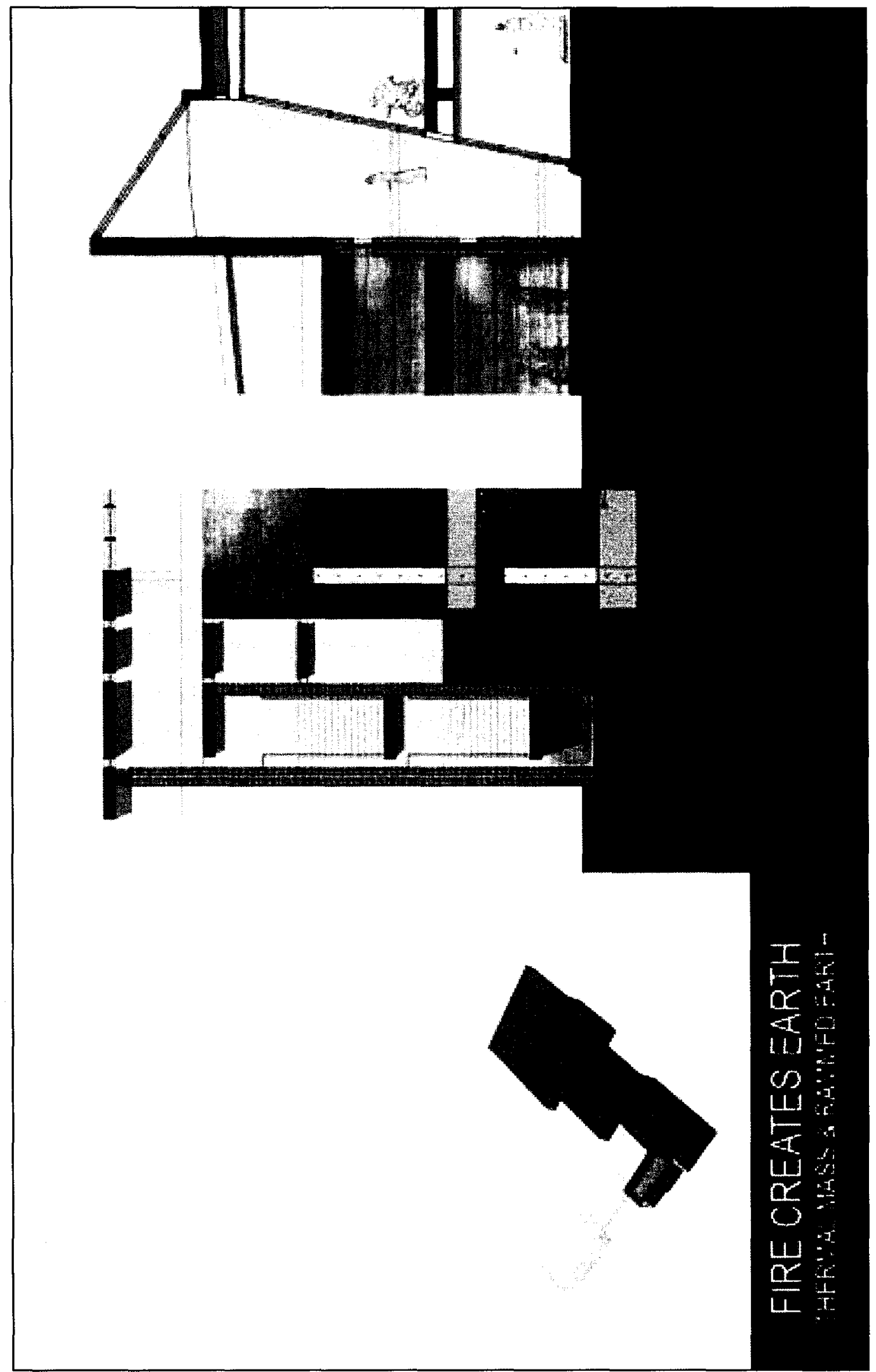

Plate 9 Detail Section 2: Fire Creates Earth - Thermal Mass and Rammed Earth 


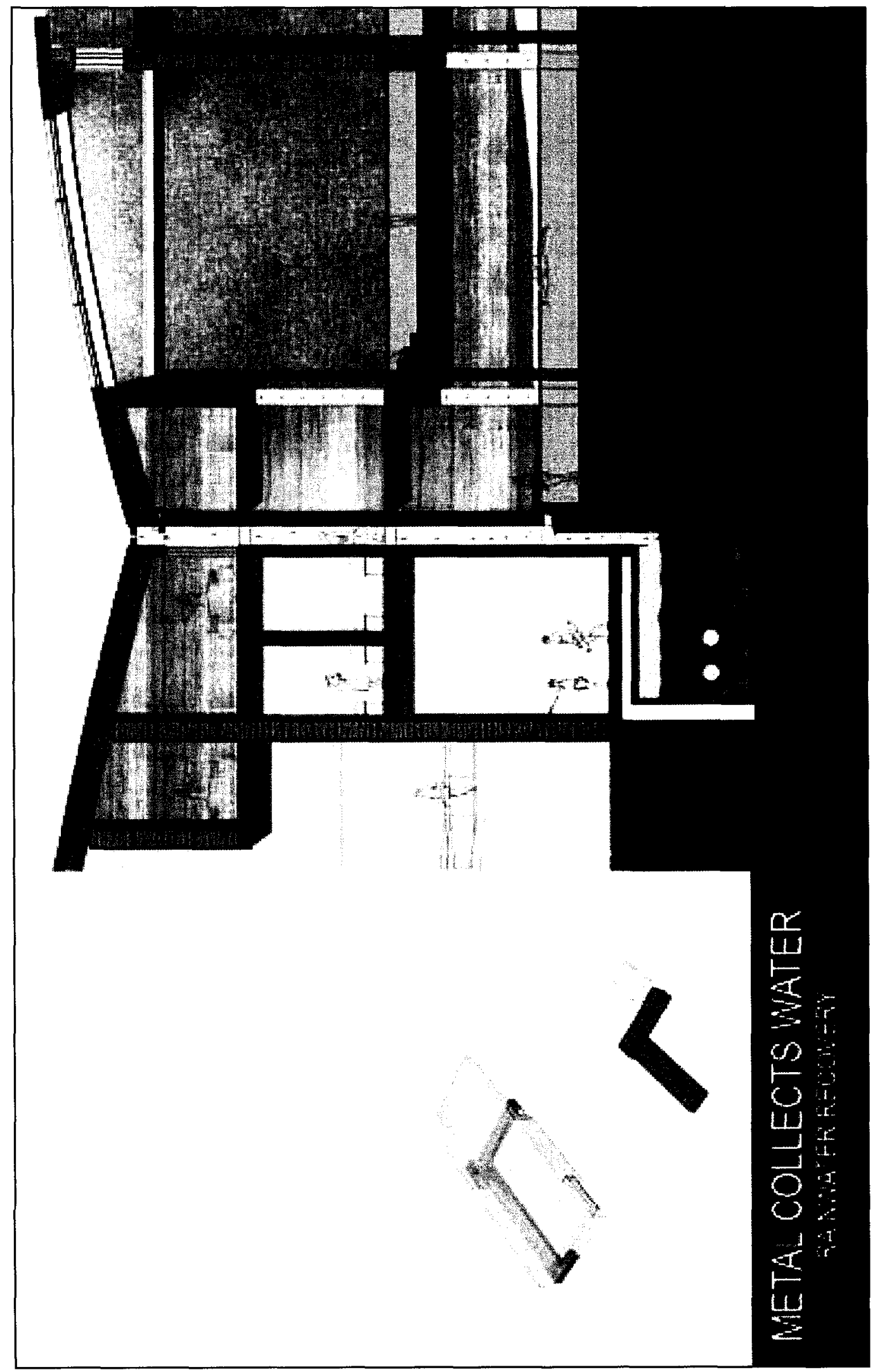

Plate 10 Detail Section 3: Metal Collects Water - Rainwater Recovery 


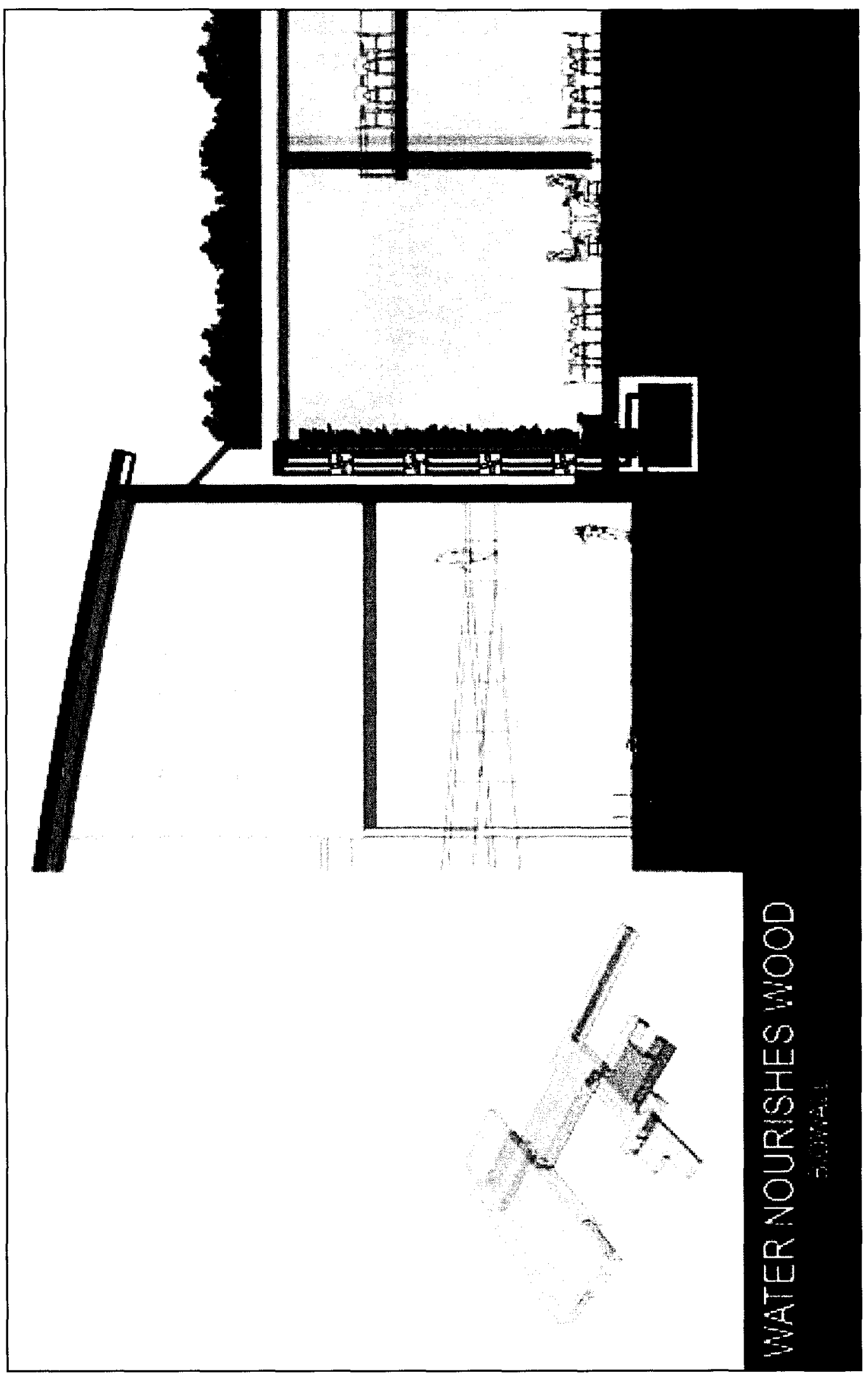

Plate 11 Detail Section 4: Water Nourishes Wood - Biowall 


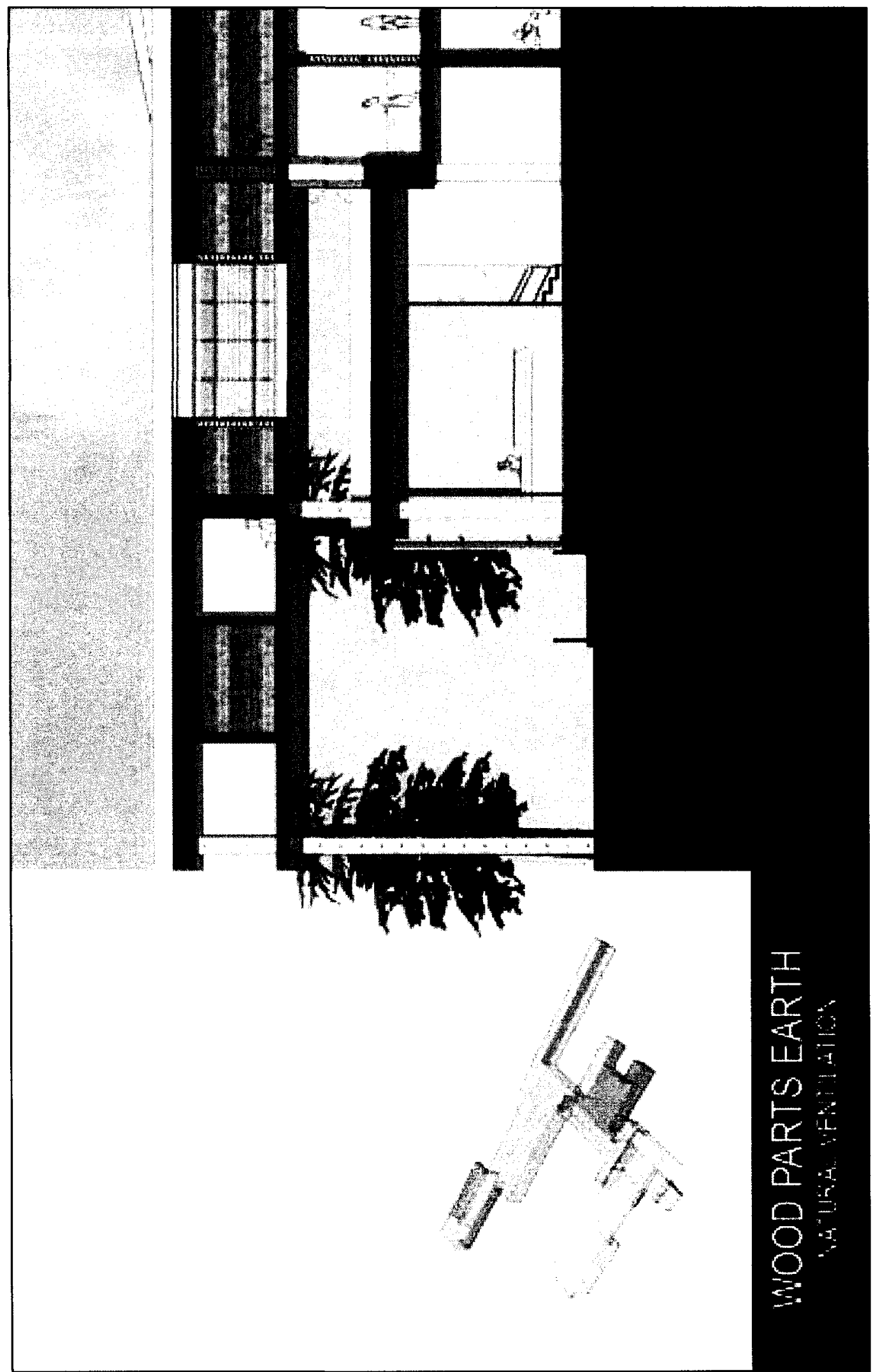

Plate 12 Detail Section 5: Wood Parts Earth - Natural Ventilation 


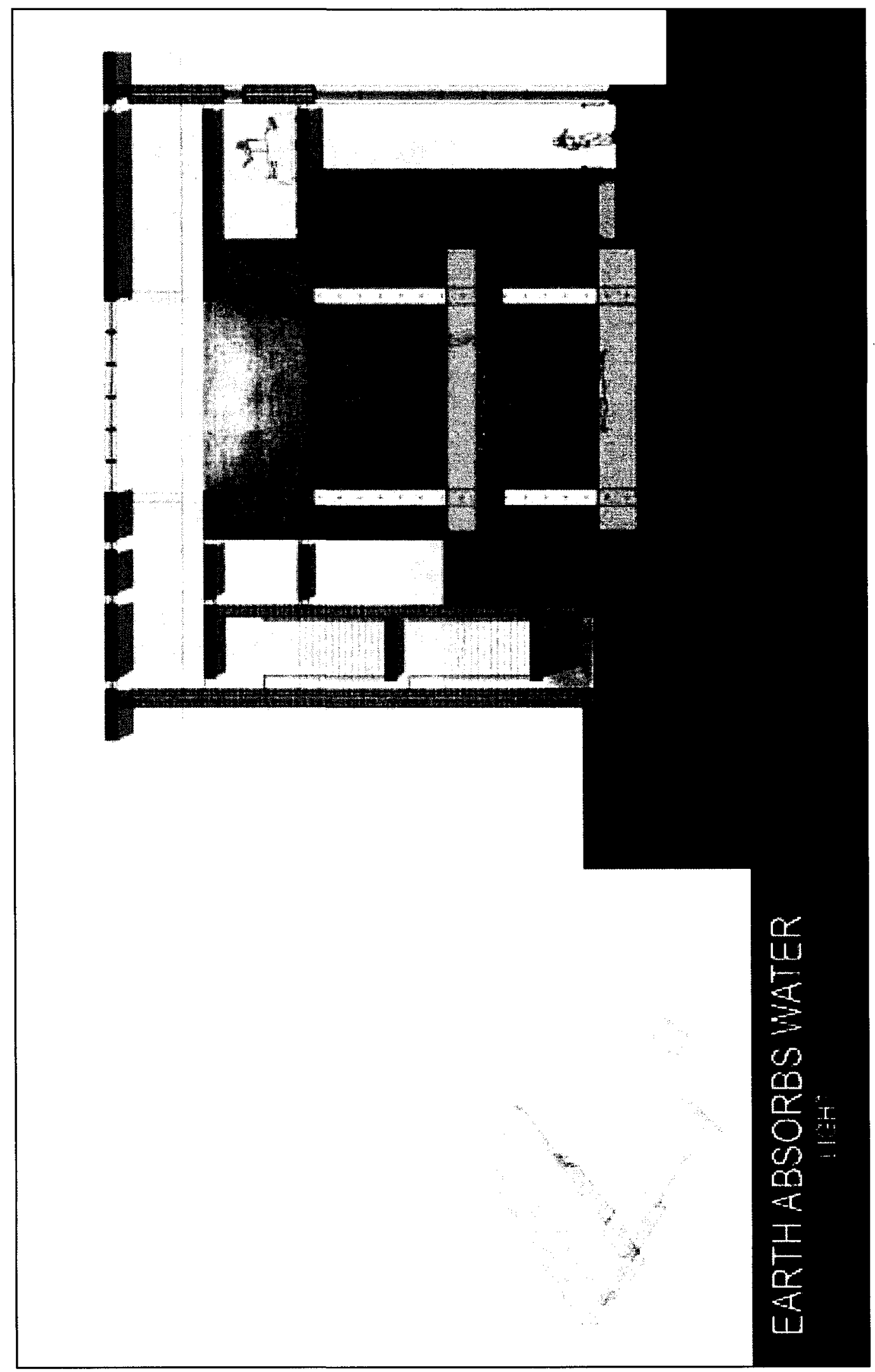

Plate 13 Detail Section 6: Earth Absorbs Water - Light 


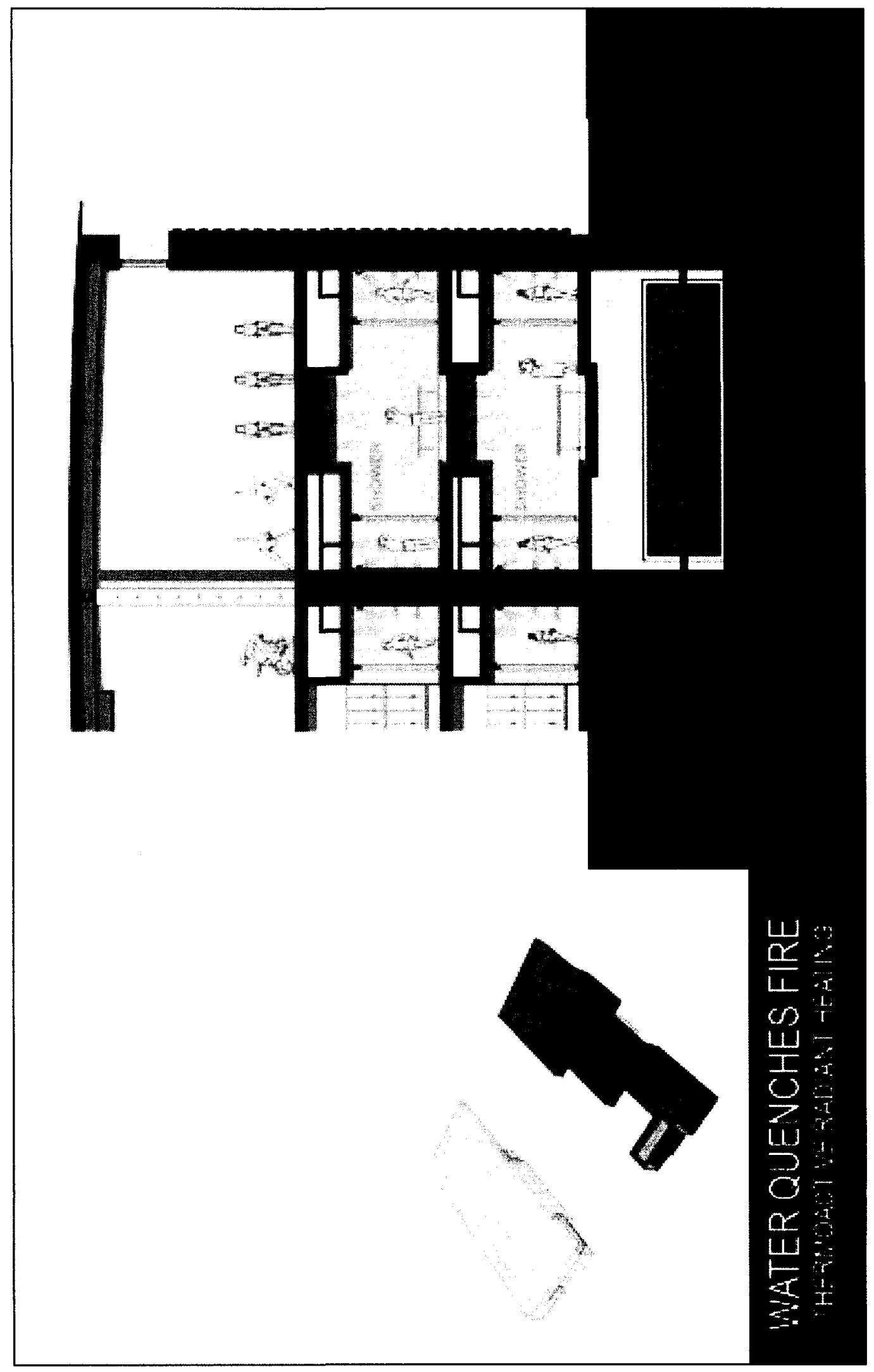

Plate 14 Detail Section 7: Water Quenches Fire - Thermoactive Radiant Heating 


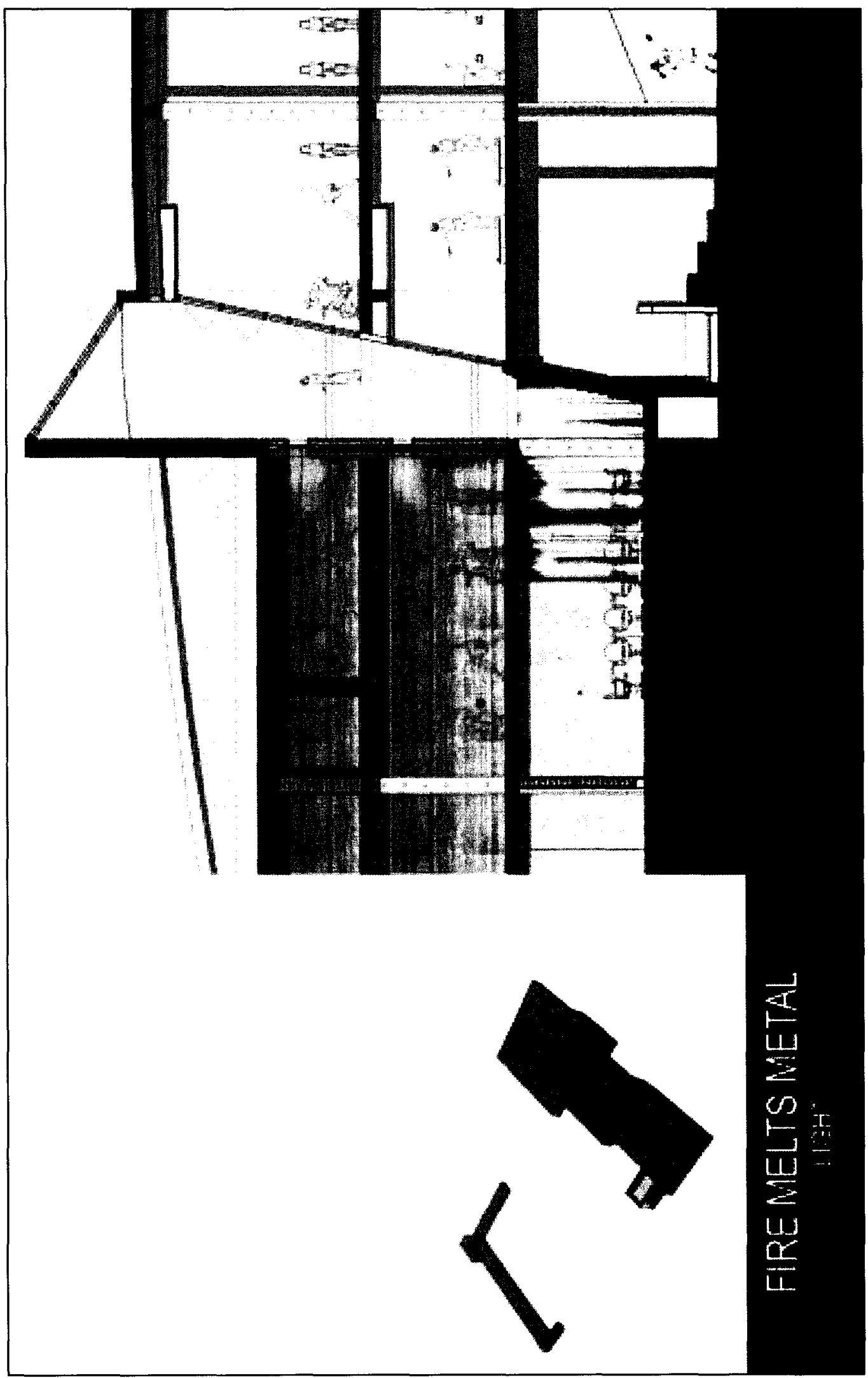

Plate 15 Detail Section 8: Fire Melts Metal - Light 


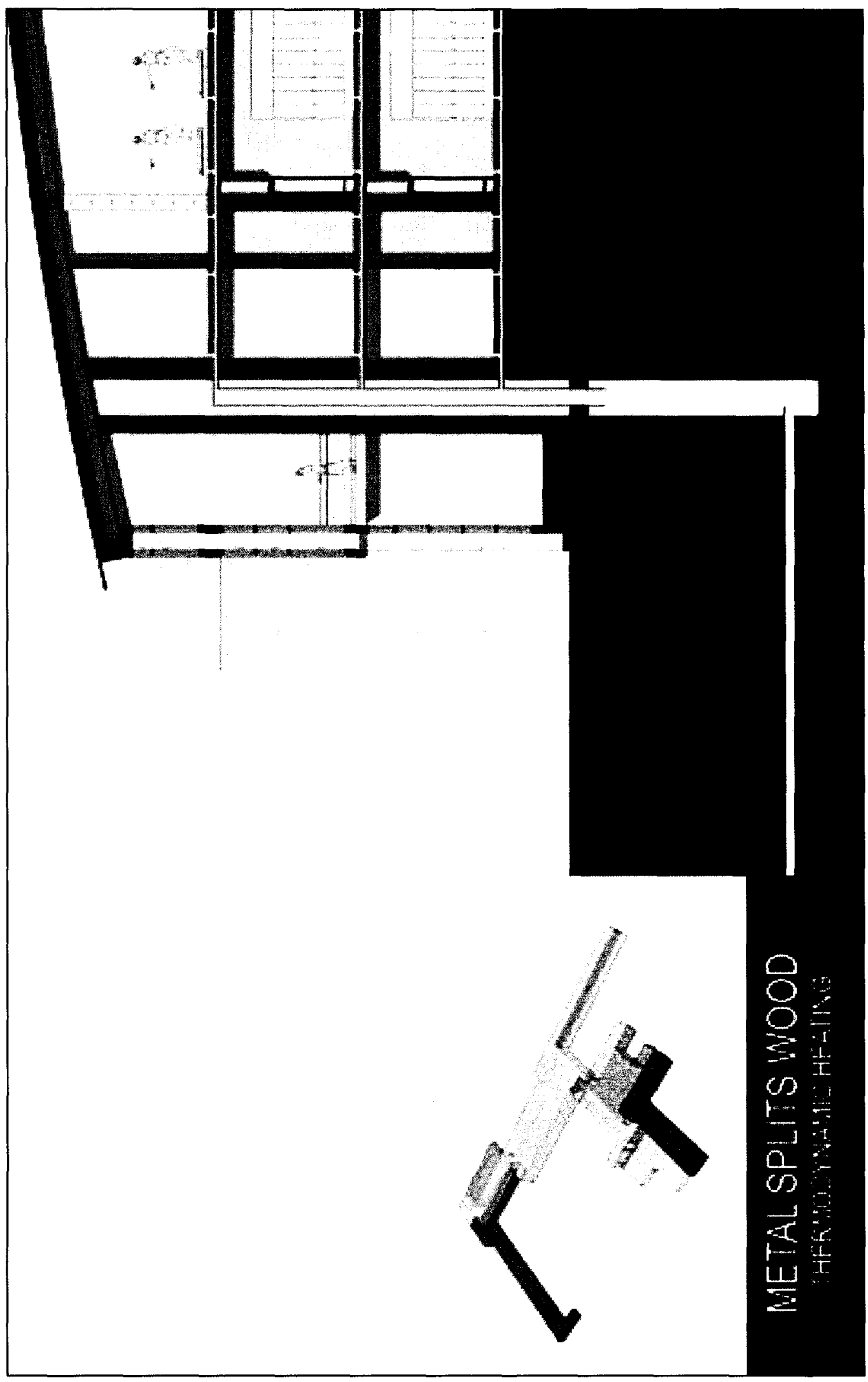

Plate 16 Detail Section 9: Metal Splits Wood - Thermodynamic Heating 

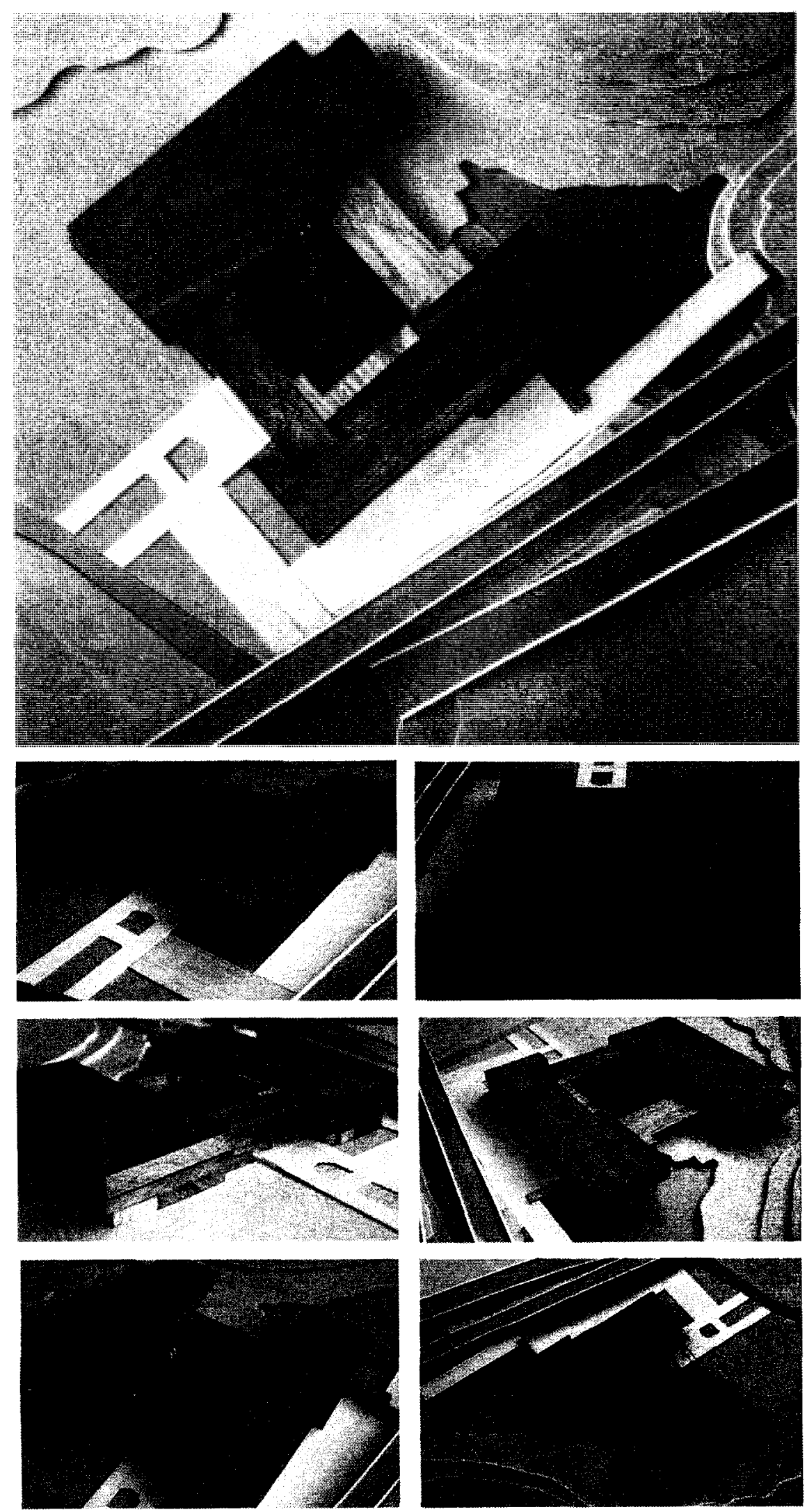

Plate 17 Images of Model 